\title{
PERFORMANCE OF A STORMWATER FILTER AND BACTERIA INACTIVATION USING BIOCIDAL MEDIA
}

A Master's Thesis Presented to the Faculty of

California Polytechnic State University

San Luis Obispo

\author{
In Partial Fulfillment of \\ The requirements for the degree of \\ Master of Science in \\ Civil and Environmental Engineering
}

By

Alex Scott Bowerman

March 2010 
(C) 2010

Alex Scott Bowerman

ALL RIGHTS RESERVED

- ii - 


\section{COMMITTEE MEMBERSHIP}

TITLE:

PERFORMANCE OF A STORMWATER FILTER

AND BACTERIA INACTIVATION USING

BIOCIDAL MEDIA

AUTHOR:

Alex Scott Bowerman

DATE SUBMITTED:

March 2010

COMMITTEE CHAIR: $\quad$ Yarrow Nelson, Ph.D.

COMMITTEE MEMBER: Tryg Lundquist, Ph.D.

COMMITTEE MEMBER: Benali Burgoa, Ph.D. 


\begin{abstract}
PERFORMANCE OF A STORMWATER FILTER AND BACTERIA INACTIVATION

USING BIOCIDAL MEDIA
\end{abstract}

\begin{abstract}
Alex Scott Bowerman
There are many possible ways to mitigate stormwater pollution, but this study focused on the DrainPac ${ }^{\mathrm{TM}}$ catchment basin insert and the feasibility of integrating N-halamine biocidal brominated beads into the filter system. This study was divided into three sections. The first section involved testing a DrainPac ${ }^{\mathrm{TM}}$ filter for treatable flow rates, head loss, and removal of solids, oil, and bacteria. The DrainPac ${ }^{\mathrm{TM}}$ filter is designed to be installed in a stormwater catch basin. The filter is composed of a $12 \times 41$ inch metal frame with textile filter media attached to it in a basket shape. The upper portion of one panel of the filter basket is made from a plastic mesh to allow overflow if the filter is overloaded. The second section of this study involved testing N-halamine brominated biocidal beads in laboratory-scale columns, and the third section involved integrating the beads into the DrainPac ${ }^{\mathrm{TM}}$ filter and testing it full scale.
\end{abstract}

For the DrainPac ${ }^{\mathrm{TM}}$ filter tests, the unit was installed into a custom-built test flume which was designed to mimic the conditions that would be encountered in a real stormwater application. The flume was supplied with a gravity-fed stream of water from a retention pond located on the Cal Poly, San Luis Obispo campus. The initial tests were conducted 
to determine the amount of head loss produced by the filter. First, the clean filter was subjected to flow rates between 20 and 200 GPM. The filter showed very minimal head loss $(0.5$ to $9.1 \mathrm{~cm}$ for 20 to $200 \mathrm{GPM})$ when not loaded with solids. Next, the filter was subjected to $200 \mathrm{GPM}$ flow with a solids concentration of between 80 and $100 \mathrm{mg} / \mathrm{L}$ until it failed (overflowed). This occurred after $625 \mathrm{~g}$ of solids had been added to the filter. After the filter had been loaded with solids to the point of overflow at 200 GPM, it was tested to determine what flow rate could be filtered with the solids present. The fully loaded filter was able to pass a flow rate of up to 80 GPM before overflowing.

The DrainPac ${ }^{\mathrm{TM}}$ filter removed solids at a range of efficiencies from 83 to $91 \%$ at flow rates between 20 and 200 GPM. The higher removal efficiencies were achieved at the lower flow rates. The filter removed oil at efficiencies ranging between 40 and $80 \%$. The oil removal efficiency did not appear to depend on the flow rate. The DrainPac ${ }^{\mathrm{TM}}$ filter did not remove bacteria under the test conditions.

Following the DrainPac ${ }^{\mathrm{TM}}$ experiments, $0.3 \mathrm{~mm}$ and $0.8 \mathrm{~mm}$ diameter N-halamine brominated biocidal beads were tested in the lab using a laboratory glass column. At flow rates between 0.28 and $1.4 \mathrm{~mL} / \mathrm{sec}$, a $1 \mathrm{~cm}$ bed height of the $0.3 \mathrm{~mm}$ beads was found to produce head losses between 19 and $51.7 \mathrm{~cm}$. The $0.8 \mathrm{~mm}$ beads produced head losses ranging from 11.9 to $47.7 \mathrm{~cm}$ when tested over the same range of flow rates. These flow rates represent nominal velocities between 0.36 and $1.8 \mathrm{~cm} / \mathrm{sec}$ which would be expected in the DrainPac ${ }^{\mathrm{TM}}$ filter. The beads were then tested to determine how effectively they inactivate bacteria in a stream of water. Contact time after flowing through the column 
was found to be the key factor in how efficiently the beads worked. When the effluent samples were instantly quenched with sodium thiosulfate, the bacteria removal results matched those observed for the control (beads without bromine). When the samples were quenched directly after collection by adding the sodium thiosulfate to the sample as soon as the desired sample volume had been collected (95 to 285 seconds depending on flow rate), between 95 and over 99 percent of the bacteria were inactivated. After 10 minutes, all of the bacteria were inactivated.

The final test involved integrating the N-halamine brominated beads into the DrainPac ${ }^{\mathrm{TM}}$ filter for a full scale test. Two sleeves containing 1400 grams of beads were laid into a DrainPac $^{\mathrm{TM}}$ filter which was custom built to concentrate the flow through the beads. This system was tested using pond water with an average of $298 \mathrm{CFU} / 100 \mathrm{~mL}$ coliform bacteria at a flow rate of 36 GPM. The results of this test were very similar to the results of the lab scale testing. Contact time again proved to be necessary for bacteria inactivation. The filter with integrated N-halamine beads removed between 72 and 100\% of bacteria with contact time between 30 seconds and 10 minutes. 


\section{Acknowledgments}

This project was funded by United Stormwater Inc. I would like to thank Israel

Rabinowitz, Tony Baird, and Ed Perry for all their advice, support, and knowledge.

Without their help, this project would not have been possible.

I would like to thank Dr. Yarrow Nelson for all of his knowledge, experience, support, and recommendations. I would also like to thank Yarrow for his patience! Dr. Nelson had a very positive impact on my college experience, and I can't thank him enough.

I would also like to thank Dr. Ben Burgoa and the Irrigation Training and Research Center (ITRC). Dr. Burgoa was especially helpful during the DrainPac ${ }^{\mathrm{TM}}$ testing portion of this experiment. He also had a way of bringing us back to reality when our minds wandered to far fetched ideas.

I would like to thank Dr. Tryg Lundquist for his contributions and support throughout the experiment..

I would like to thank Ryan MacLure for keeping me company during those long walks across campus, endless hours in the lab, numerous board meetings, and the great stormwater site visit to Costa Rica. I would also like to thank Ian Woertz for the good company and endless support in the lab. 
I would also like to thank Alice Hamrick from the Cal Poly Biological Sciences

Department for allowing me to use the equipment, and helping with coliform counts.

And finally, I would like to thank my family and friends for their support throughout my college years. 


\section{Table of Contents}

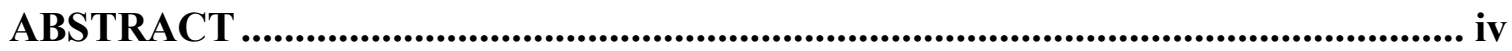

Acknowledgments............................................................................................ vii

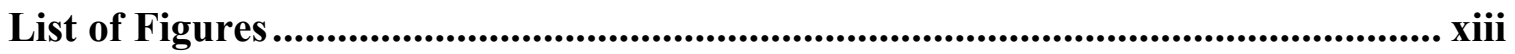

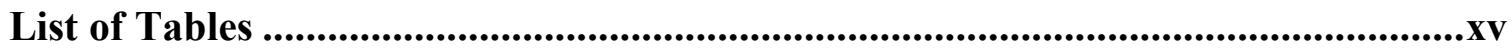

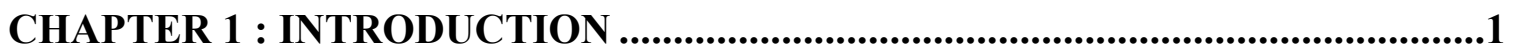

CHAPTER 2 : BACKGROUND..................................................................4

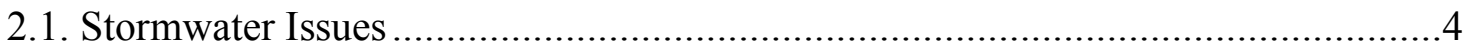

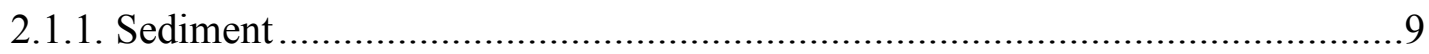

2.1.2. Oil, Grease and other Hydrocarbons .................................................... 13

2.1.3. Harmful Bacteria............................................................................... 15

2.2. Stormwater Treatment................................................................................. 18

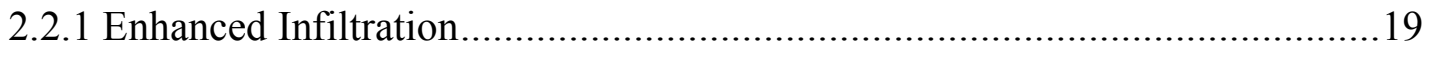

2.2.2 Media Filtration .............................................................................. 21

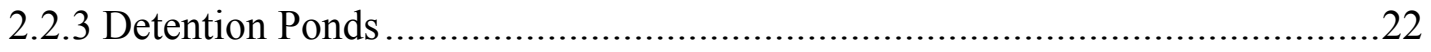

2.2.4 Catchment Basin Filter Inserts........................................................23

2.2.5 Stormwater Disinfection......................................................................25

CHAPTER 3 : MATERIALS AND METHODS...............................................29

3.1. DrainPac ${ }^{\mathrm{TM}}$ Filter Testing .....................................................................29

3.1.1. Construction of Testing Apparatus .......................................................29 
3.1.2. Clean Filter Head Loss Determination............................................................

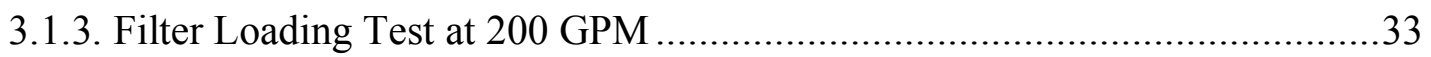

3.1.4. Loaded Filter Head Loss Determination ......................................................33

3.1.5. Sediment Removal Efficiency Determination ................................................33

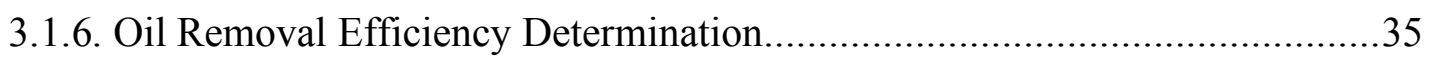

3.1.7. Coliform Bacteria Removal Efficiency Determination.....................................37

3.2. N-halamine Brominated Biocidal Bead Testing in Laboratory Columns...............37

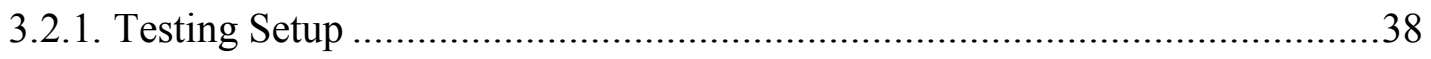

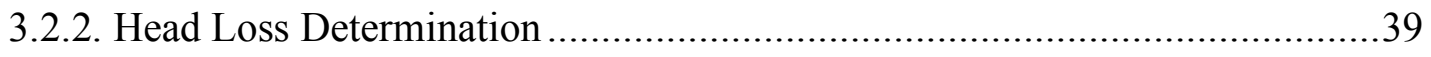

3.2.3. Quenching with Sodium Thiosulfate..........................................................4

3.2.4. Testing with Pond Water in DrainPac ${ }^{\mathrm{TM}}$ Filter Conditions..............................43

3.2.5. Testing with Lab-Grown E. coli Strain K-12 ..............................................43

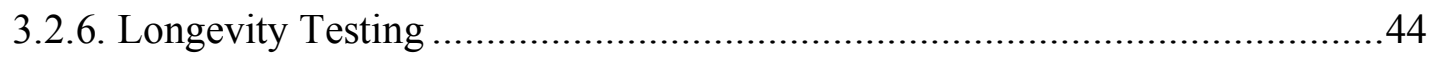

3.2.7. Control Test using Beads not activated with Bromine...................................45

3.3. Full-Scale Testing of N-halamine Beads in the DrainPac ${ }^{\mathrm{TM}}$ Filter .......................46

CHAPTER 4 : RESULTS AND DISCUSSION..........................................................49

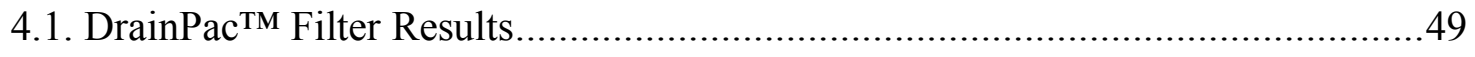

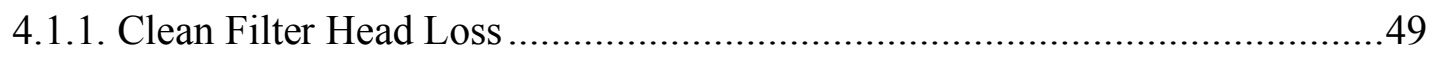

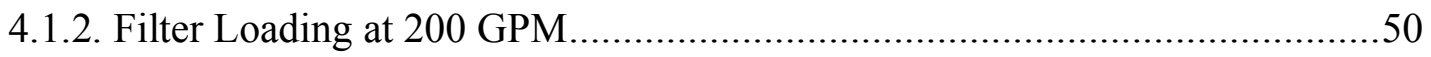

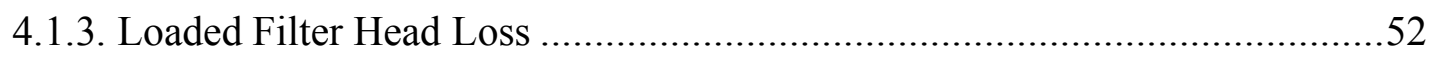

4.1.4. Sediment Removal Efficiency .................................................................52

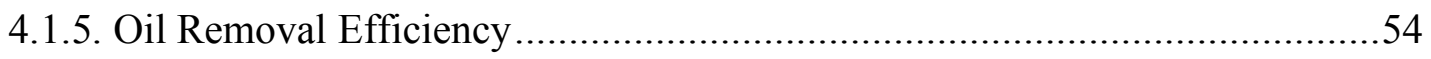


4.2. Results of Laboratory-Scale Testing of N-halamine Beads ...............................55

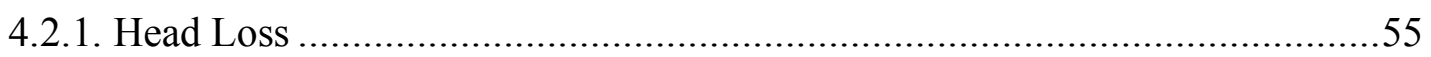

4.2.2. Results of Control Test with Beads not Activated with Bromine...................60

4.2.3. Coliform Bacteria Removal Efficiency with Pond Water using $0.3 \mathrm{~mm} \mathrm{~N}$ -

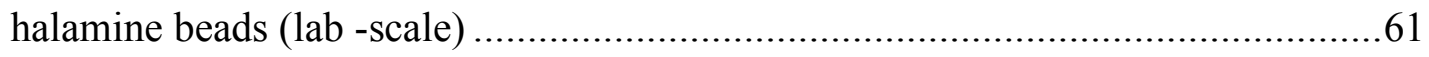

4.2.4 Coliform Bacteria Removal Efficiency with Pond Water using 0.8 mm N-

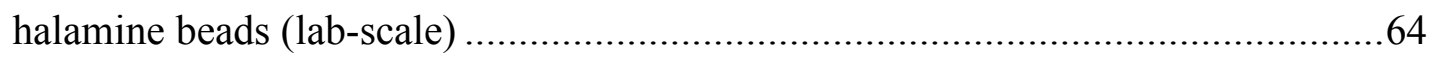

4.2.5. Bacterial Removal Efficiency using $0.3 \mathrm{~mm}$ N-halamine Beads with E. coli

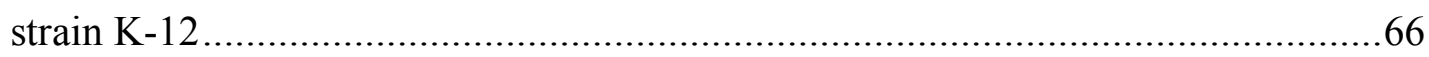

4.2.6. Bead longevity tests with $0.3 \mathrm{~mm} \mathrm{~N}$-halamine beads (lab-scale) ..................67

4.3. Full-Scale Testing of N-halamine Beads in the DrainPac ${ }^{\mathrm{TM}}$ filter ....................69

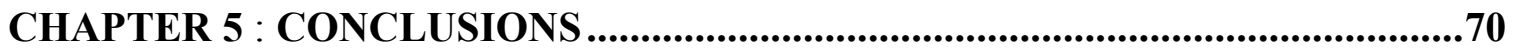

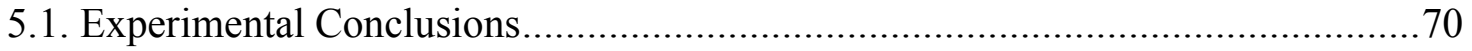

5.1.1. DrainPac ${ }^{\mathrm{TM}}$ Filter Conclusions without N-halamine beads.........................70

5.1.2. N-halamine Biocidal Brominated Bead Conclusions (Laboratory Column)...72

5.1.3. Longevity of N-halamine Beads in Laboratory Column Experiments ...........73

5.1.4. Full Scale DrainPac ${ }^{\mathrm{TM}}$ filter with N-halamine Bead conclusions ...................73

5.1.5. Bromine leaching from N-halamine beads ......................................... 74

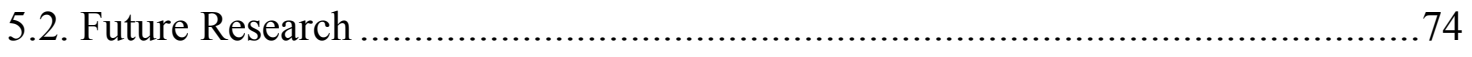

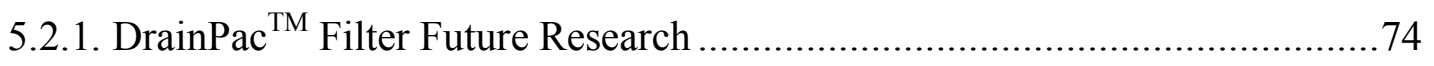

5.2.2. N-halamine Brominated Biocidal Bead Future Research ..........................75 
5.2.3. Full-Scale Testing of N-halamine Beads in DrainPac ${ }^{\mathrm{TM}}$ Filter

Future Research

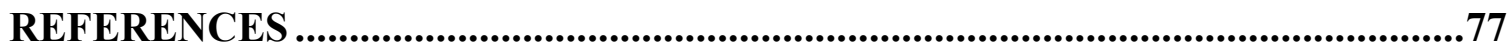

Appendix A. Colilert ${ }^{\circledR}$ method procedure..........................................................81

Appendix B. Raw data from TSS removal testing.................................................83

Appendix C. Raw data from oil testing.....................................................................84 


\section{List of Figures}

Figure 1. Sediment-laden stormwater flows into a catchment basin.............................9

Figure 2. Sediment-laden water flows into a receiving water..................................11

Figure 3. Oil slick on a pavement surface ....................................................... 14

Figure 4. Public health advisory from San Luis Obispo County .................................16

Figure 5. Example of low impact development to maximize infiltration.......................20

Figure 6. Design of a typical dry detention pond .............................................23

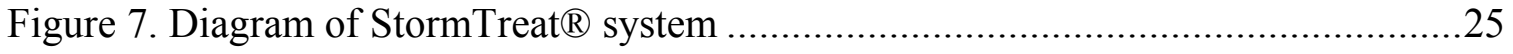

Figure 8. StormTreat ${ }^{\circledR}$ system installed in a landscaped area .................................26

Figure 9. Chemical structure of brominated N-halamine beads (Chen et al., 2004b)......27

Figure 10. Flume for DrainPac ${ }^{\mathrm{TM}}$ filter testing .....................................................29

Figure 11. DrainPac ${ }^{\mathrm{TM}}$ filter installed in test flume ............................................. 30

Figure 12. Mixing chamber and weir installed in test flume ...................................31

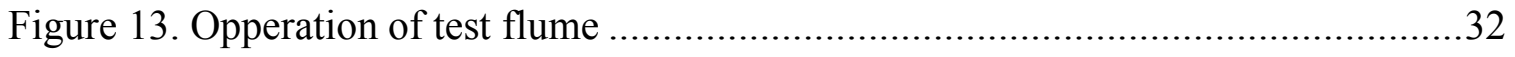

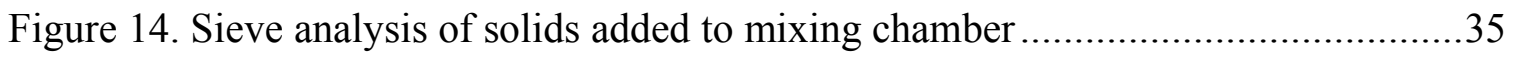

Figure 15. Glass column packed with $0.8 \mathrm{~mm}$ N-halamine beads.............................39

Figure 16. Column testing apparatus with manometer installed...............................40

Figure 17. Design of Full Scale N-halamine Bead Testing in DrainPac ${ }^{\mathrm{TM}}$ Filter...........47

Figure 18. Clean filter head loss as a function of flow rate ..................................50

Figure 19. Head losses through the DrainPac ${ }^{\mathrm{TM}}$ filter as a function of solids

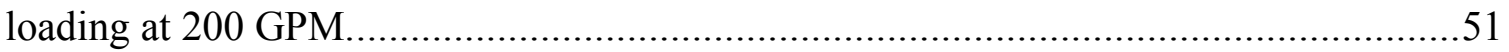

Figure 20. TSS removal efficiency as a function of flow rate in the DrainPac ${ }^{\mathrm{TM}}$ filter.. .53

Figure 21. Head losses through the column system and $0.3 \mathrm{~mm} \mathrm{~N}$-halamine beads ........57 
Figure 22. Head loss through $0.3 \mathrm{~mm}$ beads alone.

Figure 23. Head losses through the laboratory column and $0.8 \mathrm{~mm}$ N-halamine

beads

Figure 24. Head loss through $0.8 \mathrm{~mm}$ beads alone 59 


\section{List of Tables}

Table 1. Comparison of rainfall, stormwater, combined wastewater, and municiple

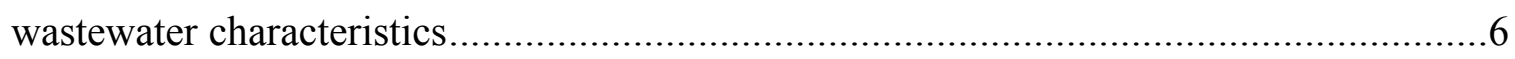

Table 2. Summary of previous DrainPac ${ }^{\mathrm{TM}}$ filter testing.......................................24

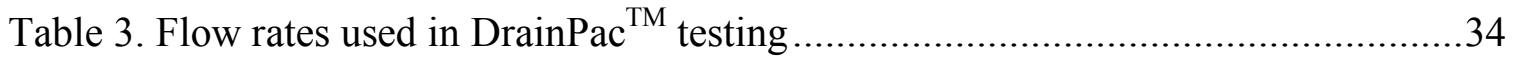

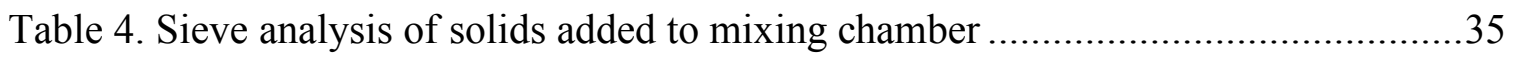

Table 5. Flow Rates Used in Head Loss Testing ...............................................41

Table 6. Clean filter head loss as a function of flow rate ......................................49

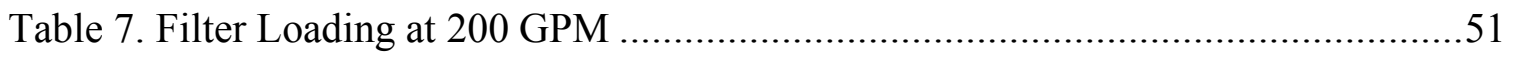

Table 8. Solids Removal Efficiency of the DrainPac ${ }^{\mathrm{TM}}$ Filter..................................53

Table 9. Oil removal efficiency in the DrainPac ${ }^{\mathrm{TM}}$ filter as a function of flow rate.........54

Table 10. Results of bacteria inactivation testing with the DrainPac ${ }^{\mathrm{TM}}$ filter ................55

Table 11. Head loss through a packed column of $0.3 \mathrm{~mm}$ beads..............................56

Table 12. Head loss through a packed column of $0.8 \mathrm{~mm}$ beads...............................58

Table 13. Results of control test with $0.3 \mathrm{~mm}$ beads in laboratory column at a flow

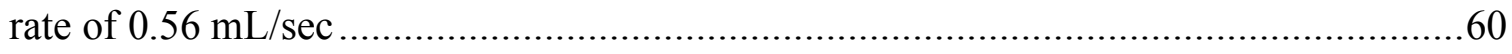

Table 14. Results of control test with $0.8 \mathrm{~mm}$ beads in laboratory column at a flow

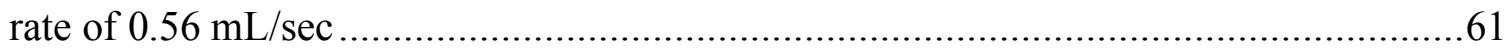

Table 15. Results of bacteria inactivation testing of $0.3 \mathrm{~mm}$ beads in a laboratory

column

Table 16. Effluent bromine concentrations from the laboratory column with

$0.3 \mathrm{~mm}$ and $0.8 \mathrm{~mm}$ biocidal beads at $0.56 \mathrm{~mL} / \mathrm{sec}$ (MacLure, 2009) 
Table 17. Results of bacteria inactivation testing of $0.8 \mathrm{~mm}$ beads in a laboratory column.

Table 18. Bacteria inactivation efficiency of $0.3 \mathrm{~mm}$ beads and high concentrations of $E$. coli at $0.56 \mathrm{~mL} / \mathrm{sec}$ .66 Table 19. Results of bead longevity test with $0.3 \mathrm{~mm}$ beads after five $1-\mathrm{hr}$ flow

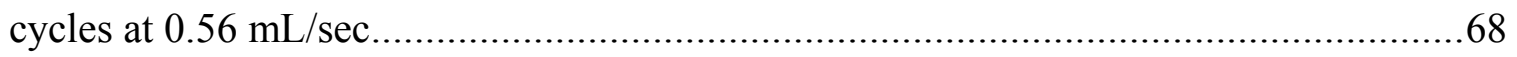
Table 20. Results of bead longevity test at $0.56 \mathrm{~mL} / \mathrm{sec}$ with $0.3 \mathrm{~mm}$ beads allowed

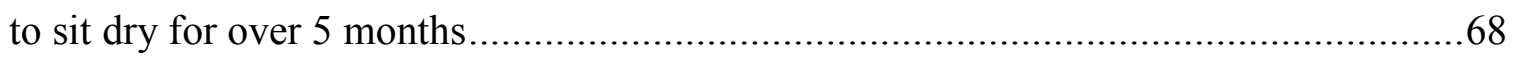
Table 21. Results of full scale testing of N-halamine beads. .69 


\section{CHAPTER 1: INTRODUCTION}

Contaminants in stormwater pose a major threat to surface water quality throughout the world. As early as the 1960's, researchers were concerned with pollution from urban stormwater (Geldreich, et al., 1968). Because stormwater comes from a variety of sources, it contains a diverse variety of contaiminants, making it difficult to manage (Hipp, et al., 2006). Many methods have been tested and implemented in an effort to control non-point pollution from stormwater. While best management practices (BMPs) are often used to reduce the contaminant loading to stormwater, another method used to control the flow of pollutants to surface waters from city streets is the use of catchment basin filters (Morgan et al., 2005). These filters are placed directly under the storm sewer curb inlets to intercept contamination before it enters the storm sewer system. These filters can potentially prevent the need for other more expensive and land-use intensive treatment facilities, such as detention basins or gravel filters. While these filters can potentially be very effective at removing contaminants, the effectiveness varies between models (Morgan et al., 2005). The purpose of the research described in this thesis was to test a commercially available stormwater filter and then improve the filter by incorporating biocidal polymer filter media for coliform bacteria inactivation.

This project is divided into three separate tasks. The first involves testing a DrainPac ${ }^{\text {TM }}$ storm drain catchment basin filter, manufactured by United Stormwater. The filter is composed of a $12 \times 41$ inch metal frame which supports a hanging filter basket composed of textile filter media. The upper portion of one wall of the filter basket is composed of plastic mesh to allow for overflow if the filter is overloaded. The filter was installed in a 
custom-built test flume, and subjected to a variety of challenges to determine how well it removed sediment, bacteria, and oil. The next tests were conducted in the laboratory to determine the head loss and bacteria inactivation efficiency of N-halamine brominated biocidal beads. These beads were developed by Dr. Seth Worley at Auburn University. The final tests involved integrating the $\mathrm{N}$-halamine beads into the DrainPac ${ }^{\mathrm{TM}}$ filter and testing for bacteria inactivation efficiency of the full scale system.

The DrainPac ${ }^{\mathrm{TM}}$ filter was tested using a wooden flume, which was custom-built to simulate the conditions found in a storm drain catch basin. Before testing the filter's contaminant removal efficiencies, preliminary tests were conducted to determine the head loss through the filter. This information was used to determine a reasonable range of flow rates which can be handled. Tests were also conducted to determine how the head loss through the filter varied as it was loaded with solids, and how much flow can be passed through the filter after it is fully loaded with sediment to the point of overflow. Water from a pond located on the Cal Poly campus was gravity fed to the flume at predetermined flow rates. Contaminants including sediments and oil were added to the pond water flow to simulate conditions which are likely to be encountered in a real application.

For the second phase of the project, lab-scale tests were used to determine the effectiveness of using brominated $\mathrm{N}$-halamine biocidal beads to inactivate bacteria. A glass column was constructed to contain the beads, and Water was pumped through the column at various flow rates. Initial tests were conducted to determine the head loss through the column of beads, and establish a reasonable range of flow rates for bacterial 
testing. Samples collected during the bacteria inactivation tests were quenched with sodium thiosulfate after several predetermined contact times and then analyzed for coliform bacteria using the Colilert ${ }^{\circledR}$ method. Longevity tests were conducted to determine the resiliency of the beads after repeated use cycles, as well as prolonged dry periods.

The third portion of the project involved integrating the biocidal beads into the DrainPac ${ }^{\mathrm{TM}}$ filter and testing at full scale using the test flume. The beads were contained in a sleeve constructed from the same filter material as the DrainPac ${ }^{\mathrm{TM}}$ filter. Samples were collected directly after passing through the filter and beads, quenched after predetermined contact times, and analyzed for coliform bacteria.

Collectively, these experiments were conducted to provide guidance for the design of a single unit to capture sediment, and oil as well as inactivate bacteria. Additional experiments were conducted in a companion study by Ryan MacLure to determine whether bromine, bromide, and bromoform were leaching from the beads in harmful levels (MacLure, 2009). 


\section{CHAPTER 2: BACKGROUND}

This section describes the issue of stormwater pollution, discusses relevant legislation, briefly outlines currently used methods of stormwater treatment, and provides information about past studies conducted on the DrainPac ${ }^{\mathrm{TM}}$ filter and N-halamine beads.

\subsection{Stormwater Issues}

The United States Environmental Protection Agency (EPA) reported to Congress that for the 2004 reporting period $44 \%$ of rivers, $64 \%$ of lakes, and $27 \%$ of bays and estuaries assessed are polluted to levels that left them unsafe for fishing, swimming or other beneficial uses (US EPA, 2009). According to Chiras (2006) 65\% of water pollution in the United States is due to non-point sources. Although most point sources have been effectively controlled in the US, non-point sources remain a problem. Stormwater discharges have recently come under scrutiny, leading to new regulations. The National Pollutant Discharge Elimination System (NPDES) Stormwater Program regulates discharges from municipal separate storm sewer systems, construction activities, and industrial activities (US EPA, 2008b). Under the NPDES system, total maximum daily loads (TMDLs) are established for receiving waters, and allocations are given to each point and non-point source affecting the watershed.

The two primary sources of contaminated run-off are agricultural and urban areas. This research is focused on urban runoff. 
One of the most significant effects that development has on surface water is due to the installation of impervious surfaces. In a natural setting, rainwater falls on soil which is held in place by the roots of natural vegetation. Much of this rainwater infiltrates into the soil, where it is purified by natural processes before reaching groundwater (Murakami, et al., 2008). Under natural conditions the portion of the rainwater which does not infiltrate into the soil flows along the surface toward the receiving water body, whether it is a stream, river, lake, or the ocean, usually without picking up excessive sediment. When impervious surfaces are in place, infiltration is greatly reduced. The reduction of infiltration increases the overall volume of stormwater which must be dealt with as surface runoff. In addition to increasing the volume of flow, the impervious surfaces also confine the flow to smaller areas, which creates an even greater flow velocity (Booth, et al., 1997). This higher velocity and flow rate not only reduces the amount of settling which occurs before reaching receiving waters, but can also scour additional sediment and contaminants from the soil including trash, yard debris, sediment, oil, grease and bacteria (Table 1) (Metcalf \& Eddy, 2003). The water eventually reaches a storm drain which conveys it to creeks, rivers, or the ocean (Parker, et al., 2000). 
Table 1. Comparison of rainfall, stormwater, combined wastewater, and municiple wastewater characteristics

\begin{tabular}{|c|c|c|c|c|c|}
\hline \multirow[b]{2}{*}{ Parameter } & \multirow[b]{2}{*}{ Unit } & \multicolumn{4}{|c|}{ Range of parameter concentrations } \\
\hline & & Rainfall ${ }^{\mathrm{a}}$ & \begin{tabular}{|c|} 
Stormwater \\
Runoff $^{\text {b }}$
\end{tabular} & $\begin{array}{c}\text { Combined } \\
\text { wastewater }^{c}\end{array}$ & $\begin{array}{c}\text { Municipal } \\
\text { wastewater }\end{array}$ \\
\hline $\begin{array}{l}\text { Total suspended } \\
\text { solids, TSS }\end{array}$ & $\mathrm{mg} / \mathrm{L}$ & $<1$ & $67-101$ & $270-550$ & $120-370$ \\
\hline $\begin{array}{c}\text { Biological Oxygen } \\
\text { Demand, BOD }\end{array}$ & $\mathrm{mg} / \mathrm{L}$ & $1-13$ & 8-10 & $60-220$ & $120-380$ \\
\hline $\begin{array}{c}\text { Chemical Oxygen } \\
\text { Demand, COD }\end{array}$ & $\mathrm{mg} / \mathrm{L}$ & $9-16$ & $40-73$ & $260-480$ & $260-900$ \\
\hline $\begin{array}{c}\text { Fecal coliform } \\
\text { bacteria }\end{array}$ & $\begin{array}{c}\text { MPN/100 } \\
\mathrm{mL}\end{array}$ & & $10^{3}-10^{4}$ & $10^{5}-10^{6}$ & $10^{5}-10^{7}$ \\
\hline $\begin{array}{l}\text { Total Kjeldahl } \\
\text { Nitrogen }\end{array}$ & $\mathrm{mg} / \mathrm{L}$ & & $0.43-1.00$ & 4-17 & 20-705 \\
\hline Nitrate & $\mathrm{mg} / \mathrm{L}$ & $0.05-1$ & $0.48-0.91$ & & 0 \\
\hline Phosphorus & $\mathrm{mg} / \mathrm{L}$ & $0.02-0.15$ & $0.67-1.66$ & $1.2-2.8$ & $4-12$ \\
\hline Copper & $\mu g / L$ & & $27-33$ & & \\
\hline Lead & $\mu \mathrm{g} / \mathrm{L}$ & $30-70$ & $30-144$ & $140-600$ & \\
\hline Zinc & $\mu g / L$ & & $135-226$ & & \\
\hline \multicolumn{6}{|c|}{ adapted from Huber (1984) } \\
\hline \multicolumn{6}{|c|}{ b Adapted from US EPA (1983) } \\
\hline \multicolumn{6}{|c|}{ c Adapted from Metcalf \& Eddy (1977) } \\
\hline
\end{tabular}


The United States Environmental Protection Agency regulates non-point source pollution with legislature written in the Clean Water Act. Under Section 305(b)(1)(A) of the Clean Water Act (CWA), states, territories, and authorized tribes are required to monitor the water quality of all waters within their jurisdiction, and report the findings to the EPA. This report is known as the 305 (b) report, or the "biennial water quality report". The waters which are identified as not meeting the water quality standards for their assigned beneficial uses (drinking water source, aquaculture, aquatic habitat, etc.) are subject to Section 303 (d) of the CWA. Section 303 (d) requires that states, territories, and tribes come up with a list of all waters that are impaired beyond water quality standards. The water bodies are then ranked in terms of priority for further efforts.

For each affected water body, a total maximum daily load (TMDL) must be established for each pollutant of concern. The TMDL is the amount of pollutant loading which can be added to a receiving water without exceeding the standards in place for the beneficial uses assigned for the given water body. The loading is divided between waste load allocations (WLA), load allocations (LA) and a margin of safety (MOS). The TMDLs are designed with a large safety margin to help account for the large amount of uncertainty in watershed analysis.

$$
\mathrm{TMDL}=\sum \mathrm{WLA}+\sum \mathrm{LA}+\mathrm{MOS}
$$

The $\sum$ WLA term is the sum of pollutant loading due to all known point sources. The Clean Water Act (CWA) requires that all point sources of pollution that are discharging to surface waters obtain a National Pollutant Discharge Elimination System (NPDES) permit. The permits require that the industries and municipalities use "best management 
practices" to reduce pollution loading to the "maximum extent practicable". In order to acquire an NPDES permit for a new construction project, a Stormwater Pollution Prevention Plan (SWPPP) must be established and submitted. The SWPPP is required to outline all of the best management practices which will be implemented to help prevent pollution and sediment from reaching surface waters. In 1987, the Water Quality Act expanded the NPDES permit requirement to industrial and municipal (separate storm sewer) stormwater discharges. While this legislation might sound good, it has already fallen desperately short of the goal of all national waters being safe for recreation by 1983.

The $\sum$ LA portion of the TMDL equation is the sum of all non-point sources. The TMDL often further allocates the amount of non-point source loading which can originate from different sections of the watershed. Non-point source pollution is best dealt with through best management practices (BMPs) by the residences, businesses, and municipalities within the state (US EPA, 2008d). Common BMPs for reducing non-point source pollution include detention ponds, wet ponds, wetland basins, biofilters, media filters, hydrodynamic devices, and porous pavement. If the quality of a water body still does not meet standards after point sources have been removed and best management practices have been put in place to reduce non-point source pollution, the state can apply for Federal grant money to implement other solutions.

The following sections give a background of each of the different pollutants addressed in this project. 


\subsubsection{Sediment}

The US EPA reported to Congress for the 2002 reporting period that out of 605,540 miles of streams and rivers assessed, 100,446 miles were detrimentally affected by sediment/siltation, more than were listed as impaired by any other contaminant (US EPA, 2007). Sediment often enters receiving waters through storm sewer systems (Figure 1).

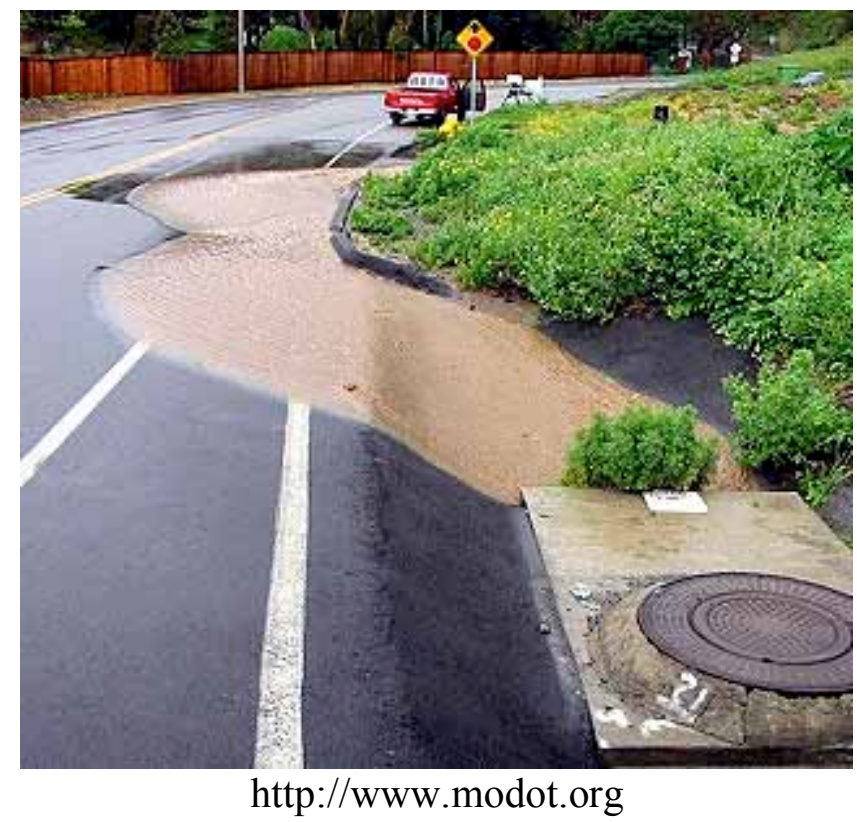

Figure 1. Sediment-laden stormwater flows into a catchment basin

When sediments enter a water body, it is not only unsightly but also highly detrimental to the ecology of the entire watershed (Figure 2). One of the most tragic effects of sedimentation is the destruction of fish spawning habitat. Many species of fish found in rivers (including salmon and steelhead) require a gravel bottom substrate to spawn successfully. When the eggs are deposited and covered with gravel, fresh water can flow through the nest, supplying oxygen and nutrients to the developing hatchlings. In waters with excessive sedimentation, these gravel areas are covered up with fine sediment, 
rendering them useless for spawning (Barnhart, 1986). If the fish are able to spawn, the young hatchlings are then challenged by lowered numbers of aquatic insects, which are a staple food source for fish. Studies have shown that numbers of these insects are significantly lower in areas affected by excessive sediment (Barnhart, 1986).

In addition to the destruction of spawning habitat, sediment has many other detrimental effects on fish. Suspended sediment in the water lowers the amount of light which can be transmitted to aquatic plants. With the aquatic plants receiving less light, photosynthesis is slowed, and less oxygen is released into the water. To make this matter worse, small silt particles can directly interfere with a fish's gills, making it even more difficult to get sufficient oxygen (Barnhart, 1986). 


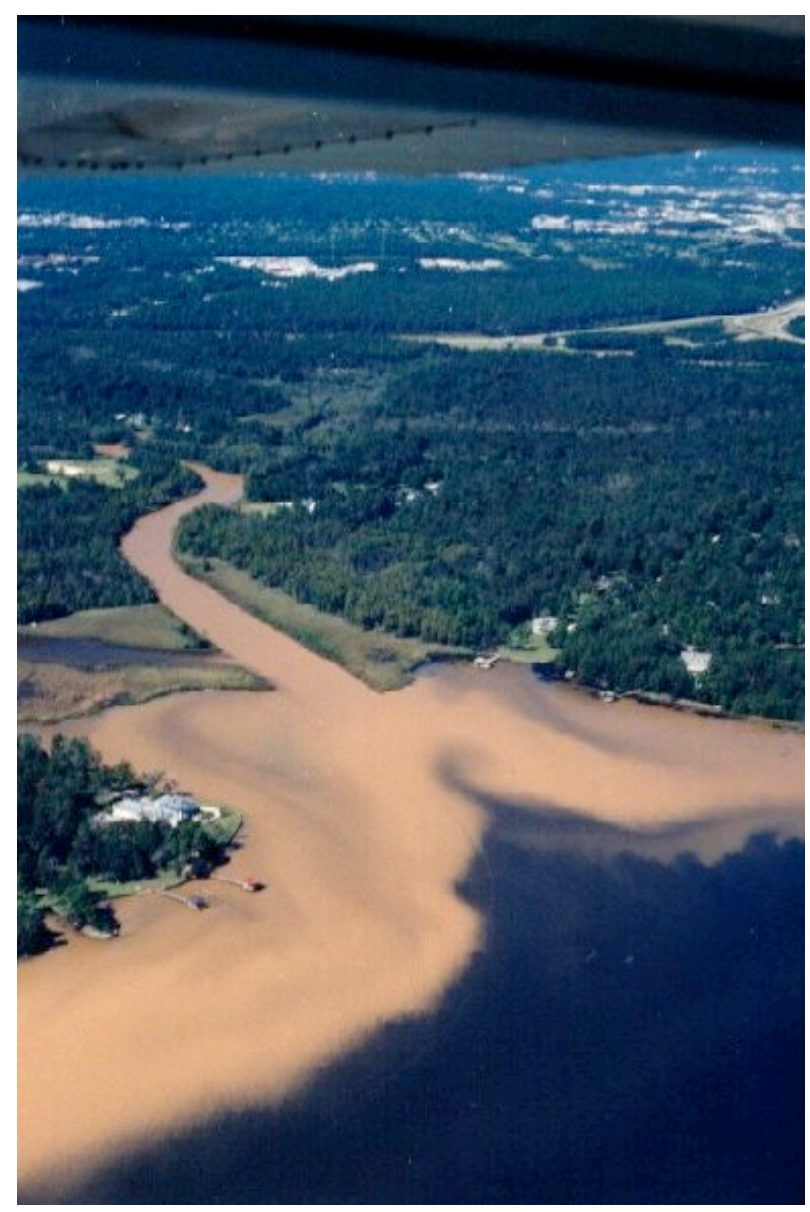

http://www.southalabama.edu

Figure 2. Sediment-laden water flows into a receiving water

As the flow rate of stormwater goes up, the concentration of sediment in the stormwater goes up as well. The concentration of TSS (sediment) in stormwater has been shown to have a power-law dependence on the stormwater flow rate. Surbeck et al. (2006) found that TSS concentration $(\mathrm{mg} / \mathrm{L})$ was related to the flow rate $\left(\mathrm{m}^{3} / \mathrm{sec}\right)$ raised to a power ranging between 0.46 and 0.64 . This is significant because increases in flow rate of stormwater not only increase the loading of solids due to the higher flow, but also because of the higher sediment concentrations due to increased scouring (Surbeck et al., 2006). 
Sediment may not be directly harmful to humans, but it certainly creates many problems with infrastructure. As sediment settles in rivers, lakes, and reservoirs, it can have drastic effects. Rivers can change course due to slow moving pools being filled with silt. Reservoirs can lose capacity as sediment fills them up. This loss of capacity increases the frequency and severity of floods. Any sediment which doesn't settle out must be removed at drinking water plants before the water is distributed. In hydroelectric plants, the suspended sediment damages turbine blades.

Sediments also carry other contaminants adsorbed to their surfaces, such as phosphate and toxic metals. Sediments can also harbor pathogens (Surbeck et al. 2006).

According to the US EPA Menu of Best Management Practices, there are many BMPs available for implementation at construction sites to prevent sediment from reaching the storm sewer (US EPA, 2008d). The most simple and logical BMP is to maintain vegetative cover whenever possible. By selecting building sites which require the least amount of excavation and grading, natural vegetation can be preserved. If grading is unavoidable, it can be completed in phases, rather than all at once. This minimizes the amount of time that soil is exposed to rain before the foundations are in place and building can begin.

If the natural vegetation must be disturbed, the US EPA Menu of Best Management Practices describes several measures which can be put in place to prevent soil particles from getting dislodged by raindrops, and brought into suspension. Compost or mulch can 
be spread over the exposed soil surface. The organic matter in compost and mulch absorbs the impact of the raindrops, preventing them from bringing the soil into suspension. Grass seed can also be added to further stabilize the soil with vegetation. Rolled erosion control products (fiber rolls) can be used to divert flows in place of compost or mulch until vegetative cover is established.

If erosion is unavoidable, measures can be put in place to contain the sediment, and prevent it from reaching the storm sewer. Silt fences, compost socks, compost berms, and fiber rolls can be placed perpendicular to slope to slow the water velocity and allow the sediment to settle out. Some degree of filtration also occurs as the water seeps through the materials. Another method is to construct a small dam using rip-rap stones, which will slow the flow of sediment-laden water enough to allow the sediment to settle out (US EPA, 2008d).

\subsubsection{Oil, Grease and other Hydrocarbons}

Many cars on the road today are leaking oil, coolant, steering and brake fluid, and even gasoline onto pavement surfaces (Figure 3). When the pavement is dry, the pollutants seep into the cracks and pores of the pavement and are relatively immobile. When it rains, the low density and hydrophobic nature of the hydrocarbons cause them to be displaced from the pavement pores by the denser rainwater. Once the hydrocarbons have released from the pavement, they are free to float along on the surface of the storm water as an oil slick. This pollution is not only unsightly (Figure 3), but also toxic to humans and wildlife (US EPA, 2008c). 
Polycyclic aromatic hydrocarbons (PAHs) are commonly detected in stormwater and accumulated sediments. There are several possible sources of this pollution. PAHs are formed through combustion, and eventually fall to the earth. One particular source of PAH contamination in stormwater is parking lot pavement seal. Research shows that parking lots sealed with coal tar based sealants produce runoff with a 100 to 1000 times higher PAH concentration than parking lots which are not sealed (Engelhaupt, 2008).

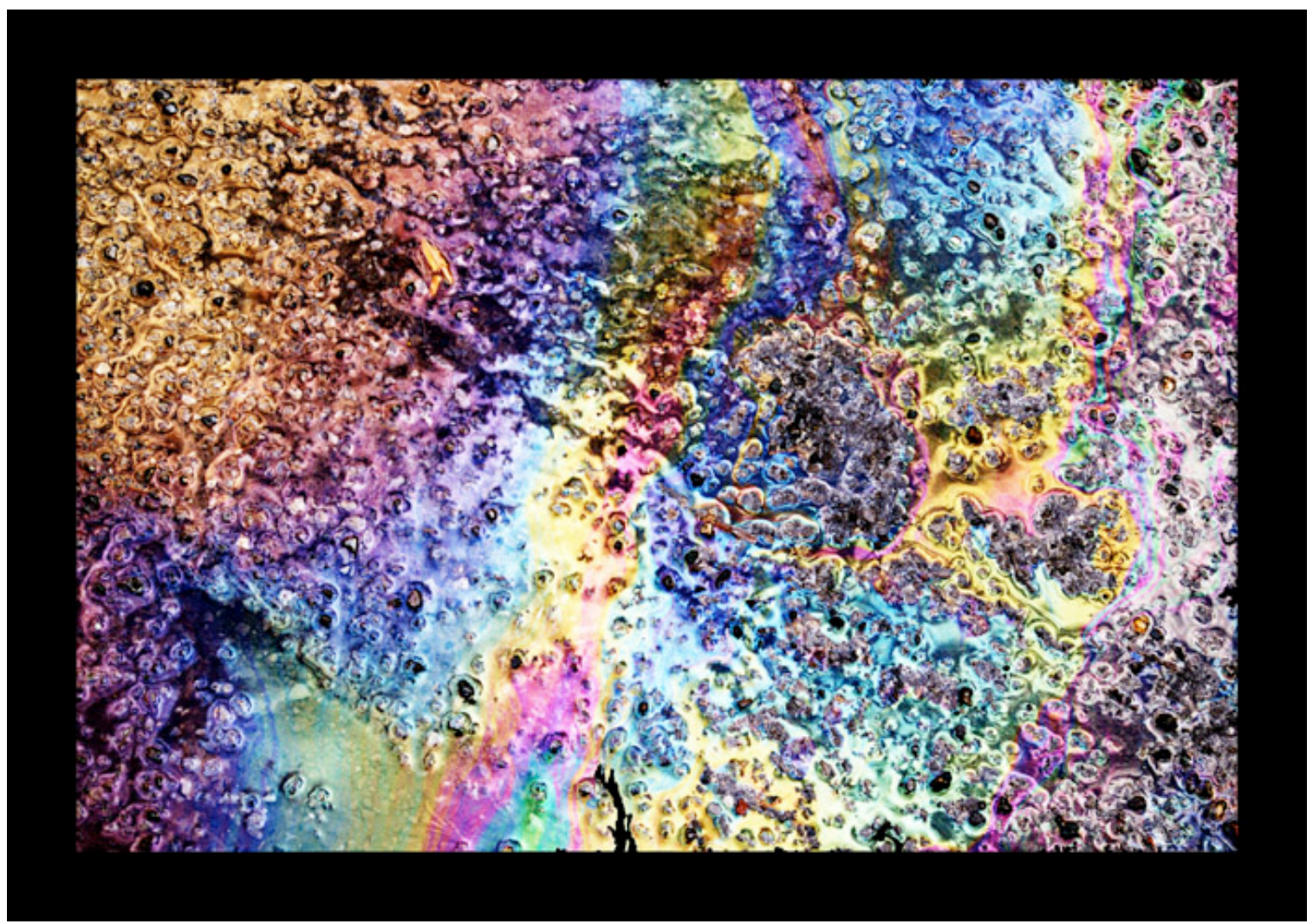

http://www.elicitwords.com

Figure 3. Oil slick on a pavement surface 


\subsubsection{Harmful Bacteria}

According to the 2004 US EPA National Water Quality Inventory: Report to Congress, more rivers, streams, and estuaries are in the 303 (d) list due to impairment from fecal coliform bacteria than any other pollutant (US EPA, 2009). This is a change from the 2002 reporting period, when sediment was listed as the top pollutant (US EPA, 2007). Fecal indicator bacteria, fecal indicator viruses, and human pathogenic viruses are all detected in urban runoff (Ahn et al., 2005). The presence of harmful, non-native bacteria in natural waters is a very significant problem. For coastal areas, the ocean is usually the ultimate receptor of this pollution. During and shortly after storm events, the ocean is inundated with foreign bacteria washed from the urban landscape (Ahn et al., 2005).

In most cases, the spike of bacteria concentrations occurs during and shortly after rain events. In urbanized areas, this concentration spike often results in bacteria levels high enough to warrant beach closures. In areas affected by this problem, signs such as that depicted in Figure 4 are often posted at public beaches warning beachgoers to avoid water contact within 72 hours of rainfall (San Luis Obispo County, 2010). 


\section{HEALTH ADVISORY}

\section{AVOID WATER CONTACT ACTIVITIES}

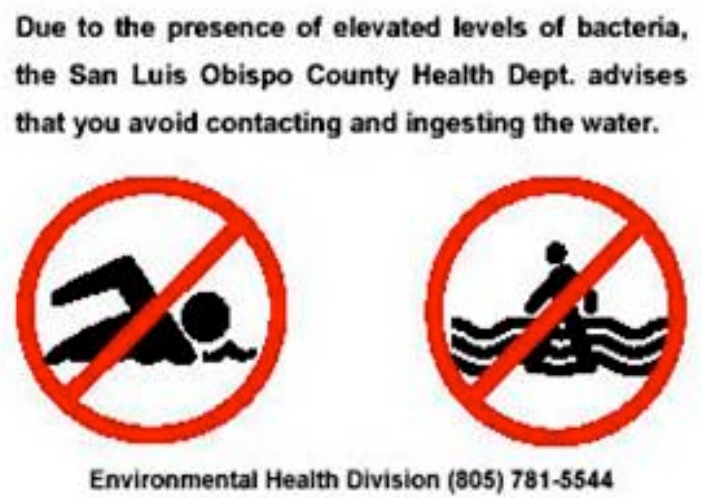

Figure 4. Public health advisory from San Luis Obispo County

When dams, weirs, reservoirs, or other flood control measures are in place, it can greatly increase the loading of bacteria to receiving waters. This sometimes becomes a problem because it stores bacteria-rich flows can be accumulated during and shortly after the rain event distributing them to the receiving water at a later time, when the weather has cleared up and people are out swimming and surfing (Ahn, et al. 2005).

Most watershed models employed today assume that bacteria follow a buildup/wash-off paradigm. In this scenario, the concentration of bacteria in the runoff would peak in the initial phases of the storm, and then begin to decline. This is also referred to as a "firstflush effect" (Stenstrom, 1998). In this scenario, it is assumed that bacteria are 
accumulating on the surface of the landscape, and are washed off as soon as the area is wetted. Research published in 2006 by Surbeck et al. contradicts this buildup/wash-off paradigm. They instead show that bacteria concentrations in stormwater increase with the initial onset of the storm, and then remain relatively constant for the remainder of the event. This implies that fecal indicator bacteria are ubiquitous in the urban landscape (not just built up on the surface), and readily transfer into runoff (Surbeck et al. 2006).

If the buildup/wash-off scenario is assumed, it can lead municipalities down the wrong path in terms of preventing harmful bacteria from reaching receiving waters. With the buildup/wash-off scenario, the current practice of diverting dry weather flows to wastewater treatment plants would make sense. If the bacteria is building up over time, it would make sense that the highest concentrations would be present during the dry season, when they have not been washed away by rain. If this were the case, diverting the small flows which occur during the dry season would greatly reduce the overall loading of bacteria. In reality, the concentrations remain an issue during the wet season (Surbeck et al. 2006). This misconception about the buildup/wash-off paradigm could lead municipalities to divert only dry weather flows, which would mean diverting only a small fraction of the total bacterial loading. This, however, does not imply that diverting dry weather flows is not beneficial. Because far more people expose themselves to lake, river, and ocean water during the summer, diverting dry weather flows is protecting a large number of people. It is usually not practical (or possible) to divert the dry and wet season stormwater flows, so other solutions need to be found (Ahn et al. 2005). 
Recent studies have sought to find the source of fecal coliform bacteria in stormwater using molecular fingerprinting. Because this is a relatively new area of science, the results have been mixed. Because it is difficult to determine the source of bacterial pollution, it is difficult to implement best management practices to prevent it. If the sources of pollution are known, more specific actions can be taken to avoid contamination of surface waters (Surbeck et al. 2006).

\subsection{Stormwater Treatment}

In addition to the best management practices which can be implemented to reduce stormwater pollutant loading, there are many methods available to treat stormwater runoff before it reaches receiving waters. Some methods that have gained popularity include infiltration in vegetated areas, porous pavement, gravel or fine media filters, detention basins, constructed wetlands and catch basin filters. These options range greatly in their required footprint, materials, treatment method, and effectiveness.

Despite the great potential for successful treatment at the urban/watershed interface, recent efforts show a lack of coordination of linkages between land use and pollutant loadings in the technical design and implementation of best management practices (BMPs) for stormwater remediation (Hipp, et al., 2006). Research has shown that using the appropriate types of storm drain filtration in strategic locations within a city can greatly reduce pollutant loading (Hipp, et al., 2006). Hipp et al. found that by matching the filter media to the land use (and expected pollutants) within a given catchment area, total maximum daily loads (TMDLs) can often be met for a watershed without costing 
the city excessive sums of money. Strategic placement of filters within a city can result in a total pollutant removal efficiency up to 5 times greater than random placement of filters (Hipp, et al., 2006).

\subsubsection{Enhanced Infiltration}

Infiltration areas, also known as rain gardens, have been recommended as a method to treat stormwater (Dietz and Clausen, 2005). Infiltration areas are unique in that their purpose is to keep water as close to where it falls as possible, without even needing to convey it to a storm sewer system (Lubick, 2006). The method relies on the intrinsic ability of the earth's soil and sand to decontaminate water that infiltrates through it. Research has shown that the total paved area of the United states is approximately equal to the area of the state of Ohio (Lubick, 2006). Massive paved area produces an excessive amount of stormwater which could have been avoided if low impact development (LID) were practiced. LID is a design approach that focuses on creating a hydrologically functional site with measures in place to mitigate the negative affects of development (US EPA, 2008a). Designing infiltration areas into new building projects is part of the LID strategy (Lubick, 2006). By maximizing the area covered with mulch and vegetation and making minor changes to the surface topography, infiltration can be maximized (Figure 5). 


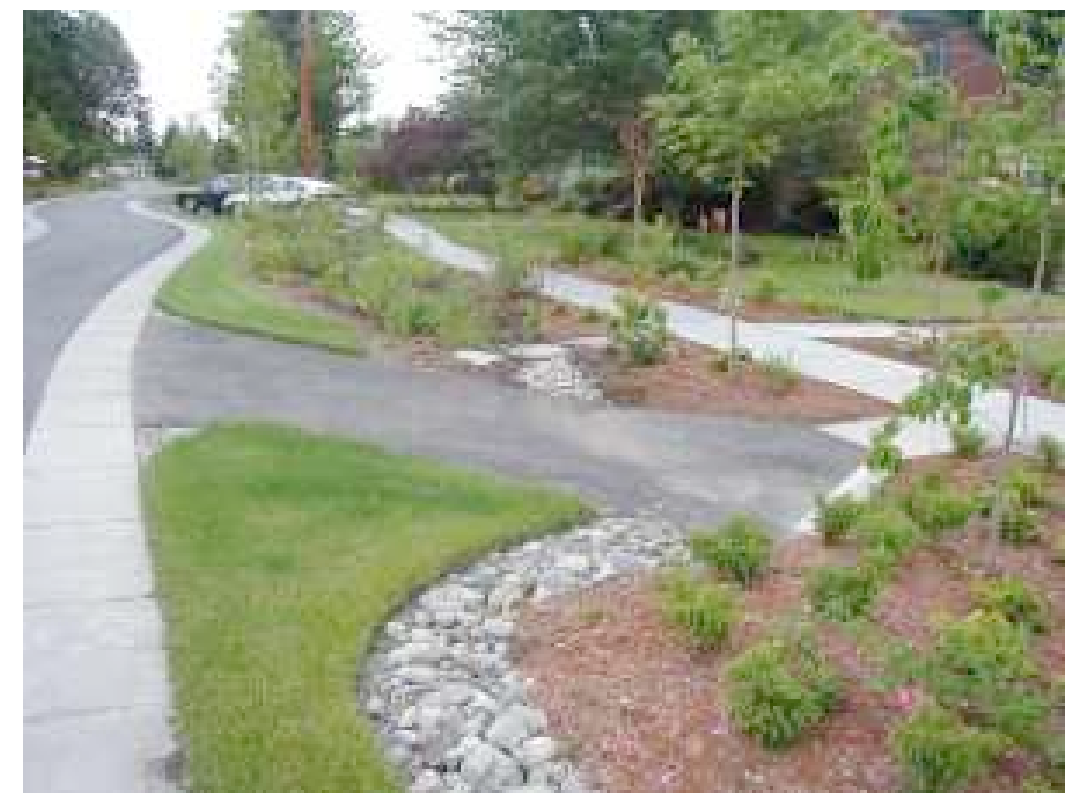

http://www.fcwc.org

Figure 5. Example of low impact development to maximize infiltration

The use of porous pavement is recommended by the US EPA as a method to control runoff volumes and flow rates (Diniz, 1980). Porous pavement can be used in place of impervious concrete in new developments, or implemented into existing infrastructure in order to reduce the overall flows in overloaded systems (Diniz, 1980). The advantages of porous pavement include reduced runoff volume, increased groundwater recharge, and increased coefficient of friction between tires and wet roadway. There are few disadvantages to the use of porous pavement, but the primary concern is clogging. If the pavement is installed incorrectly, or if excessive dirt is deposited on the pavement, it can become clogged. If the pavement is vacuumed and washed with a water jet before the dirt is packed into the pavement pores, up to 95 percent of the original permeability can be restored (Diniz, 1980). If the dirt is not cleaned out before it is compacted and ground into the pavement to a depth of greater than $1 / 2$ inch, full permeability cannot be restored 
(Diniz, 1980). Another disadvantage to porous pavement is that building codes have not been updated to provide guidelines for the new technology. Often the codes require the

placement of curbs, culverts, and other flow management infrastructure that is not needed when porous pavement is used. These requirements increase the overall project cost (Diniz, 1980).

\subsubsection{Media Filtration}

Gravel and fine media filters are commonly used technologies for managing stormwater (Hatt et al. 2008). According to research conducted by Siriwardene et al. in 2007, gravel filters are highly effective at removing sediments from stormwater, but their effectiveness diminishes over time as they become clogged. By maintaining the proper maintenance regime, the filters can remain productive for longer periods of time (Siriwardene et al. 2007). In order to account for the clogging effect, Siriwardene et al. developed a model which accounts for the addition of sediment to the filter over time when calculating the sediment removal efficiency of the filters. Using this new model, gravel filters could potentially be designed and maintained much more effectively.

While gravel media filters are effective at removing large sediment particles, they are ineffective against fine particulates and dissolved contaminants (Hatt et al. 2008). Fine media filters are much more effective than gravel filters at removing small sediments and dissolved contaminants (Hatt et al. 2008). While the fine media filter will also inevitably clog, it is much easier to maintain. In a fine media filter, the clogging occurs at the surface, where it can be scraped off. In a filter using course media such as gravel, the 
sediment settles and accumulates in the bottom of the filter, where it is very difficult to remove (Hatt et al. 2008).

\subsubsection{Detention Ponds}

According to the US EPA, detention ponds are the most commonly used form of stormwater management (US EPA, 1986). Detention ponds are simple structures built to contain stormwater for a long enough period to prevent flooding and allow sediment and contamination to settle out before the flows are released at a controlled rate. Detention ponds are either designed to remain dry between storm events (dry detention ponds) or to store a given volume of water between storm events (wet detention ponds). A typical design of a dry detention pond is shown below in Figure 6. It is difficult to determine the effectiveness of wet detention ponds because the detention time is dependent on storm intensity and longevity. Also, because detention basins are installed permanently and with fixed dimensions, their performance varies greatly with the intensity of a given storm event (US EPA, 1986). The U.S. EPA National Menu of Best Management Practices includes a table summarizing the results of 35 studies testing the pollutant removal efficiency of wet detention ponds. The TSS removal efficiencies found in these studies range from $-33.3 \%$ up to $99 \%$, and bacteria removal efficiencies range from $-6 \%$ to $99 \%$ (US EPA, 2008d). 


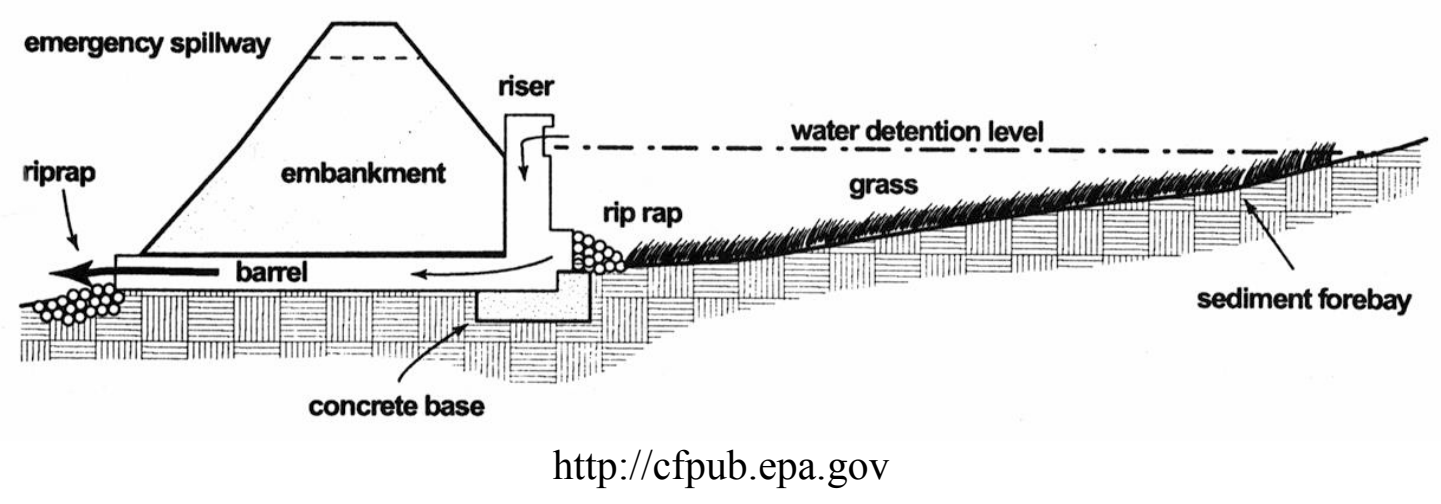

Figure 6. Design of a typical dry detention pond

\subsubsection{Catchment Basin Filter Inserts}

Another possible method to remove pollutants from stormwater is the use of filters inserted in catchment basins (Morgan et al., 2005). These filters have a great appeal to cities because they can be installed into the existing infrastructure without excessive modifications. There are many filters on the market today, covering a wide array of uses, sizes, materials, costs, and pollution removal efficiencies. Morgan et al. (2005) tested 4 storm drain filters currently on the market. The filters tested included the HydroCartridge $^{\mathrm{TM}}$, Ab Tech Ultra Urban Filter ${ }^{\mathrm{TM}}$, AguaShield ${ }^{\mathrm{TM}}$, and DrainPac ${ }^{\mathrm{TM}}$ filters $^{\mathrm{N}}$ (the filter tested in this research). In this study, water was mixed with sediment from street sweepings and introduced to the storm drain filter through a stormwater simulator. The study found that the removal efficiency depended on the flow rate, with the higher flow rates producing lower suspended solids removal efficiencies. The DrainPac ${ }^{\mathrm{TM}}$ filter used in this experiment had a depth of $50.8 \mathrm{~cm}$, and the area of the opening was 3,123 $\mathrm{cm}^{2}\left(3.4 \mathrm{ft}^{2}\right)$. The DrainPac ${ }^{\mathrm{TM}}$ was found to have an average suspended solids removal efficiency of about $25 \%$ when flow rates between 207 and 213 gallons per minute were passed through the filter for 30 minute durations (Table 2). The HydroCartridge ${ }^{\mathrm{TM}}, \mathrm{Ab}$ 
Tech Ultra Urban Filter ${ }^{\mathrm{TM}}$, and AguaShield ${ }^{\mathrm{TM}}$ filters were found to have TSS removal efficiencies of $35 \%, 45 \%$, and $10 \%$, respectively.

Stenstrom (1998) of the Civil and Environmental Engineering Department of the University of California, Los Angeles conducted tests of the DrainPac ${ }^{\mathrm{TM}}$ filter. In this study, sediment vacuumed from DrainPac ${ }^{\mathrm{TM}}$ filters which were already in service was used as the source of contamination. The filter used in this study had a $4.5 \mathrm{ft}^{2}\left(4,181 \mathrm{~cm}^{2}\right)$ opening. The filter was tested for removal of suspended solids, oil and grease, and polycyclic aromatic hydrocarbons. The study found that the DrainPac ${ }^{\mathrm{TM}}$ filter removed between 95 and $98 \%$ of the suspended solids at a flow rate of 75 gallons per minute. These suspended solids removal results are biased because the experiment used solids which had been vacuumed from a DrainPac ${ }^{\mathrm{TM}}$ filter which was already in service. Oil and grease (PAH) removal efficiency ranged between 49 and 86\%, with higher removal efficiencies when lower oil and grease concentrations were used (Table 2).

Table 2. Summary of previous DrainPac ${ }^{\mathrm{TM}}$ filter testing

\begin{tabular}{|c|c|c|c|}
\hline Study & Flow Rate & Parameter & Removal Efficiency (\%) \\
\hline Morgan et al., 2005 & $207-213$ GPM & TSS & 25 \\
\hline \multirow{3}{*}{ Stenstrom, 1998 } & \multirow{2}{*}{75} & TSS & $95-98$ \\
\cline { 3 - 4 } & & Oil and Grease & $49-86$ \\
\hline
\end{tabular}




\subsubsection{Stormwater Disinfection}

Despite the obvious need, little research has been conducted on the possibility of disinfecting stormwater before it reaches the storm sewer system. One system which has been shown to remove coliform bacteria is known as the StormTreat ${ }^{\circledR}$ system. This system utilizes a three chamber unit in conjunction with a grit bag filter and small intregrated wetland, as shown in Figures 7 and 8 (Sonstrom, et al. 2002).

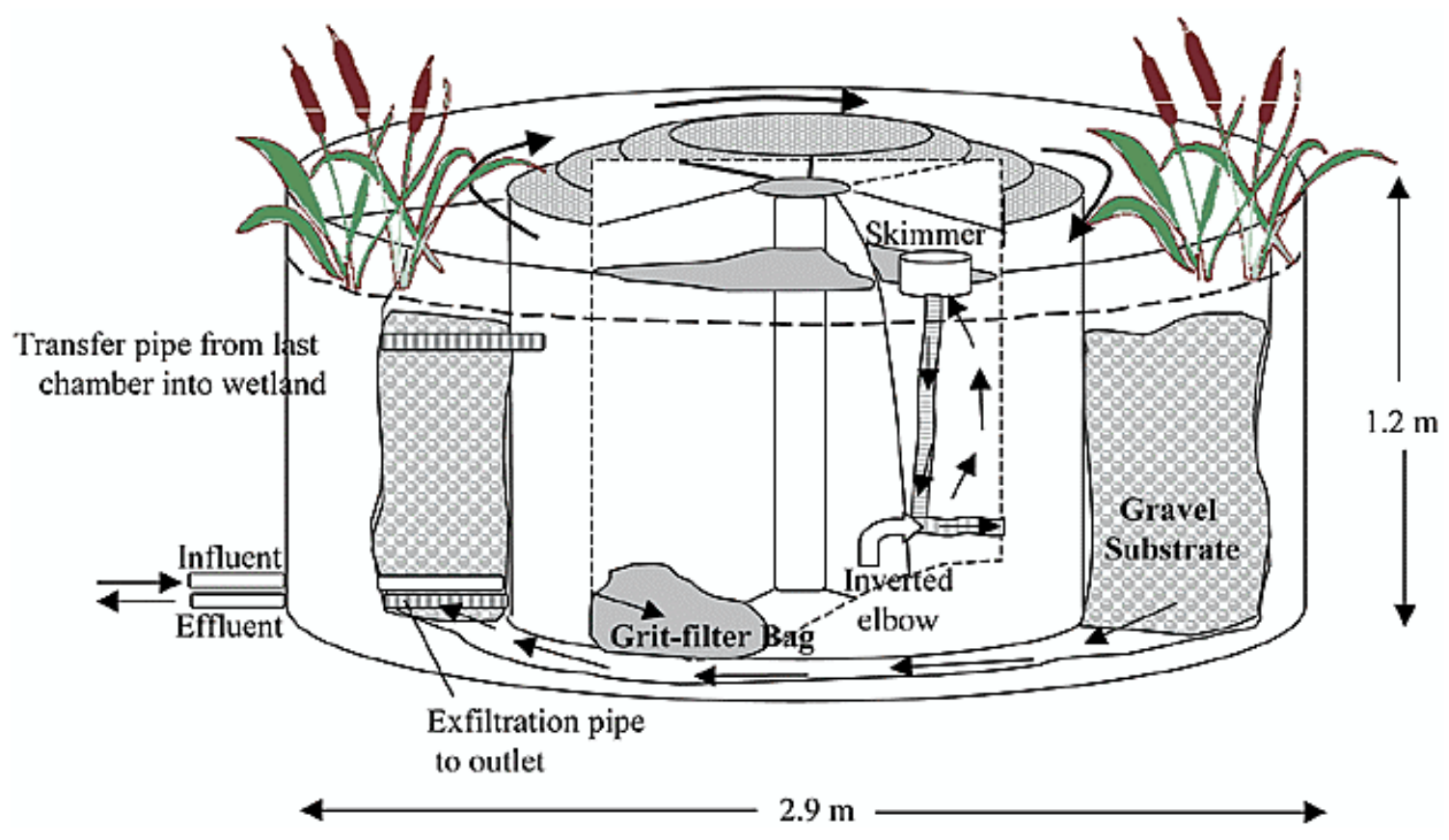

Figure 7. Diagram of Storm Treat ${ }^{\circledR}$ system

In tests conducted by Sonstrom et al., the StormTreat ${ }^{\circledR}$ system was found to remove $49 \%$ of total suspended solids, $74 \%$ total phosphorus, $44 \%$ total Kjeldahl-N, $45 \%$ total zinc, $29 \%$ total copper, $2 \%$ total lead on a mass basis, and $99 \%$ fecal coliform on a concentration basis. 


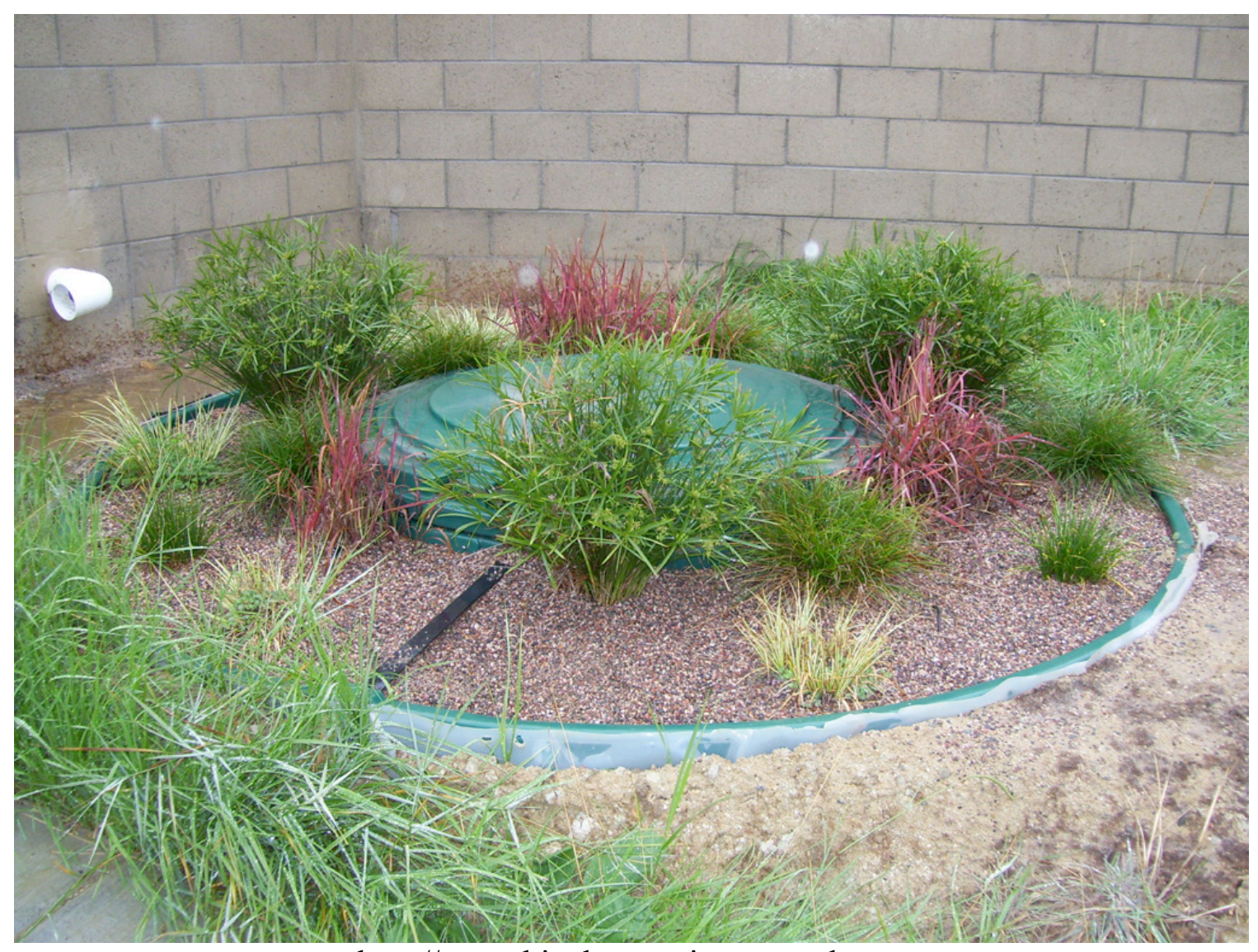

http://www.biocleanenvironmental.com

Figure 8. Storm Treat ${ }^{\circledR}$ system installed in a landscaped area

Dr. S. D. Worley of Auburn University developed biocidal polymer beads with the original purposes of disinfecting drinking water or water in recirculation systems such as spas (Sun et al., 1996). The beads are composed of poly[1,3-dichloro-5-methyl-5-(4'vinylphenyl)hydantoin] and poly[1,3-dibromo-5-methyl-5-(4'-vinylphenyl)hydantoin], or N-halamine, for short (Figure 9) (Chen et al., 2004b). In this project, N-halamine beads are tested to determine whether they could feasibly be used in a stormwater application. Prior to the development of the N-halamine beads, the polymers had been produced in a powdered granular form (Chen et al., 2004a). The material was highly effective at 
disinfecting water, but the small size of the granules caused significant head loss and clogging issues when used in cartridge filters (Chen et al., 2004a).

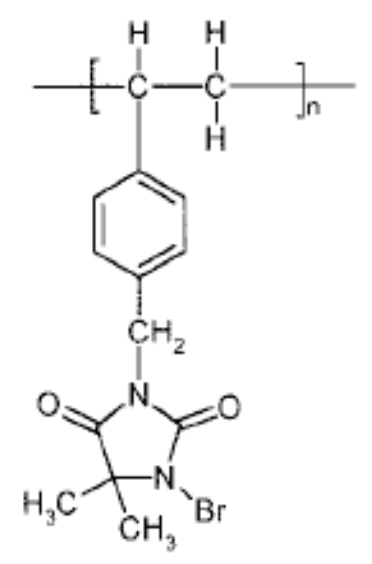

$\mathrm{PHY}-\mathrm{Br}$

Figure 9. Chemical structure of brominated N-halamine beads (Chen et al., 2004b)

The N-halamine beads were tested for their efficiency at inactivating bacteria, halogen stability, and rechargability by Chen et al. in 2003. The study used a glass packed column with an inside diameter of $1.3 \mathrm{~cm}$ and a length of about $7.6 \mathrm{~cm}$. A column containing bromine-charged N-halamine beads was first flushed with about 1 liter of chlorine demand free water, and then water containing Staphylococcus aurius at a concentration of $6.9 \times 10^{6} \mathrm{MPN} / \mathrm{mL}$ was passed through the column at a flow rate of about $3 \mathrm{~mL} / \mathrm{s}$. The effluent was quenched with $0.02 \mathrm{~N}$ sodium thiosulfate prior to plating of serial dilutions on nutrient agar. The contact time between when the water passes through the column and when it is quenched with sodium thiosulfate was not documented. As a control, columns of the same dimensions were filled with either beads that had not been charged with bromine, or beads that had been charged with bromine and then quenched with 
sodium thiosulfate. The study found that the beads caused a $6.9 \log$ decrease in the bacteria concentration after a contact time of 1.1 seconds. The control columns did not cause any decrease in active MPN concentration, indicating that the bacteria were inactivated, not merely filtered out (Chen et al. 2003). 


\section{CHAPTER 3: MATERIALS AND METHODS}

\subsection{DrainPac ${ }^{\mathrm{TM}}$ Filter Testing}

The water used to test the DrainPac ${ }^{\mathrm{TM}}$ filter was obtained from a retention pond located on the Cal Poly, San Luis Obispo campus. The water was gravity fed to the project site through six-inch pipes. The area surrounding the pond is used for cattle and horse grazing, which contributes to the natural sediment and bacteria concentrations.

\subsubsection{Construction of Testing Apparatus}

The DrainPac ${ }^{\mathrm{TM}}$ filter insert was tested using a flume constructed of wood and sealed with polyurethane sealant (Figure 10).

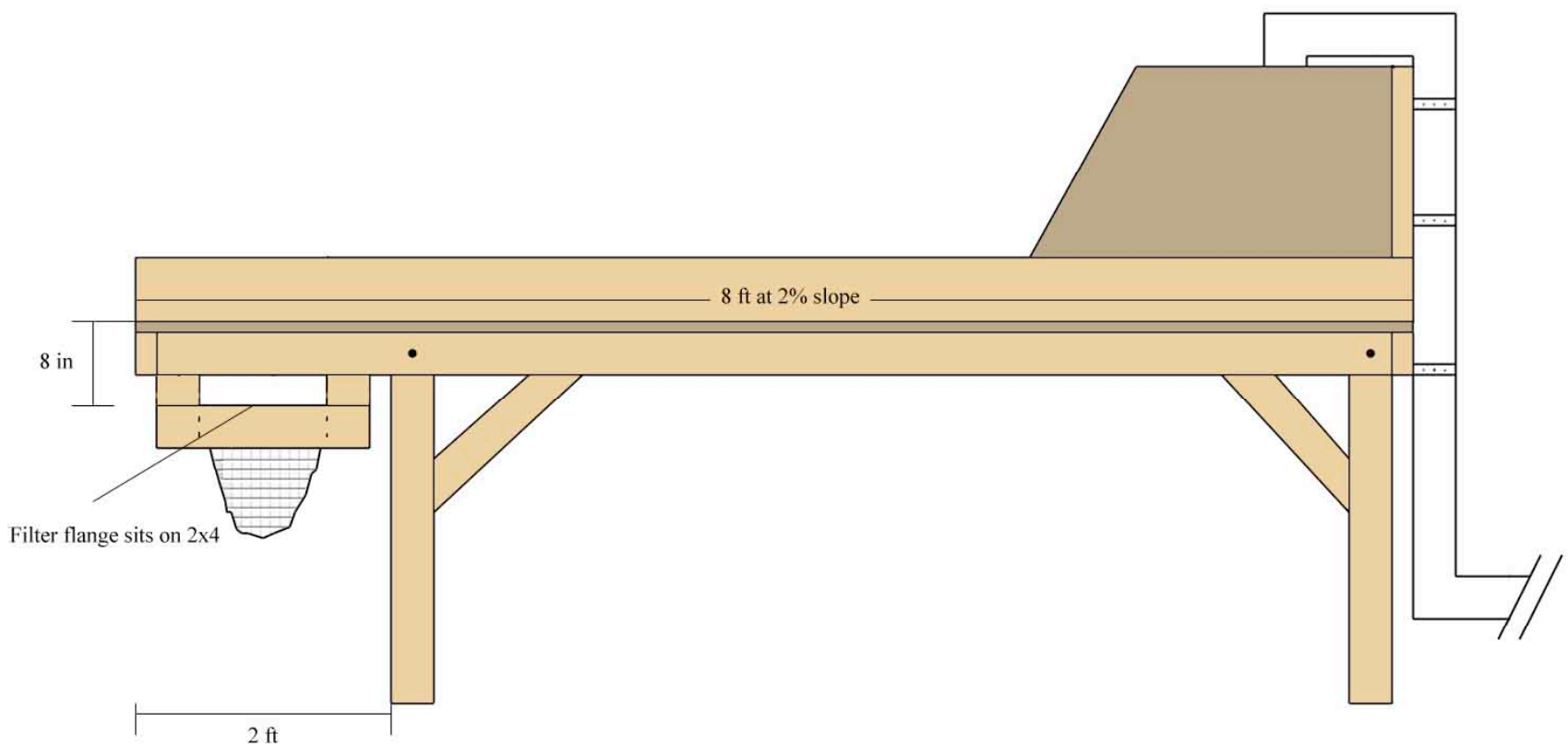

Figure 10. Flume for DrainPac ${ }^{\mathrm{TM}}$ filter testing 
The DrainPac ${ }^{\mathrm{TM}}$ filter used in this experiment was composed of a metal frame with an opening measuring 12 inches by 41 inches. Suspended from the metal frame was a cloth filter basket. One side of the filter basket was partially composed of plastic mesh to allow overflow should the filter media become clogged (Figure 11). The bed slope of the flume was $2 \%$, the bed length was eight feet, and the bed width matched the width of the filter insert (41 inches). The DrainPac ${ }^{\mathrm{TM}}$ filter was held in place by wooden supports underneath the mounting flanges located on either end of the metal frame (Figure 11 and Figure 13). Rubber weather seal and silicone sealant was used to direct all of the water flow into the filter.

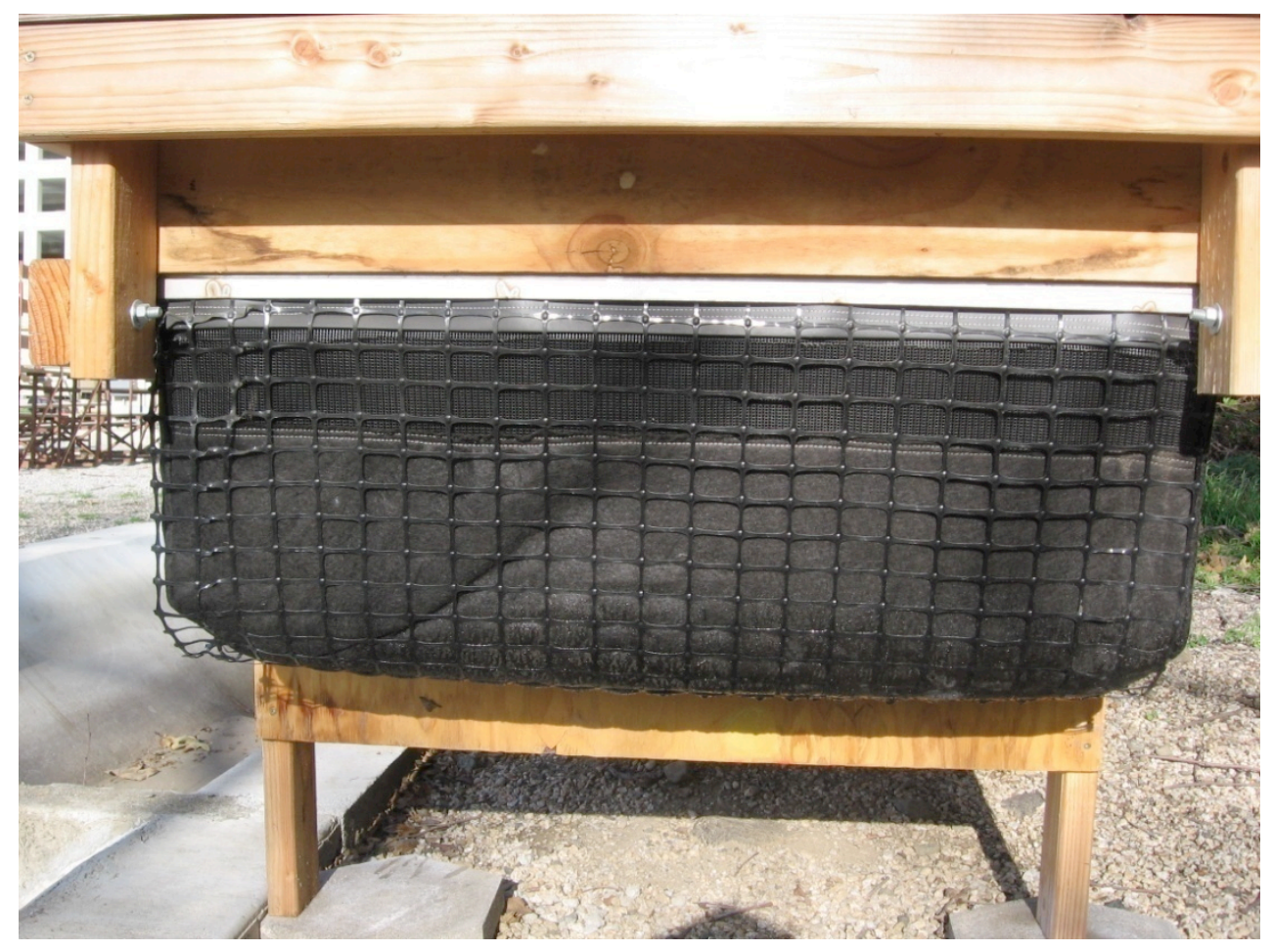

Figure 11. DrainPac ${ }^{\mathrm{TM}}$ filter installed in test flume 
Water was gravity fed to the system and flow rate was monitored using a magnetic flow meter (Seametrics). The flow meter was calibrated and checked by the Irrigation Training and Research Center (ITRC) the previous year. Straight piping sections with lengths greater than 10 times the pipe diameters were installed before and after the flow meter to ensure accurate measurement. Flow measurements were confirmed by timing the flow into 5 gallon buckets. Water entered the flume via a mixing chamber into which additional contaminants could be added (e.g. solids and oil). The mixing chamber was composed of a plastic bucket with holes cut around the base (Figure 12). At the higher flow rates of 150 GPM and 200 GPM, a metal weir was added to the flume to slow the water velocity and prevent the water from overshooting the cloth portion of the DrainPac ${ }^{\mathrm{TM}}$ filter (Figure 12). A simple wooden structure was built to convey the effluent stream to an existing concrete channel (Figure 12). Once in the channel, the water flowed by gravity to a sump pump which pumped it onto a nearby field.

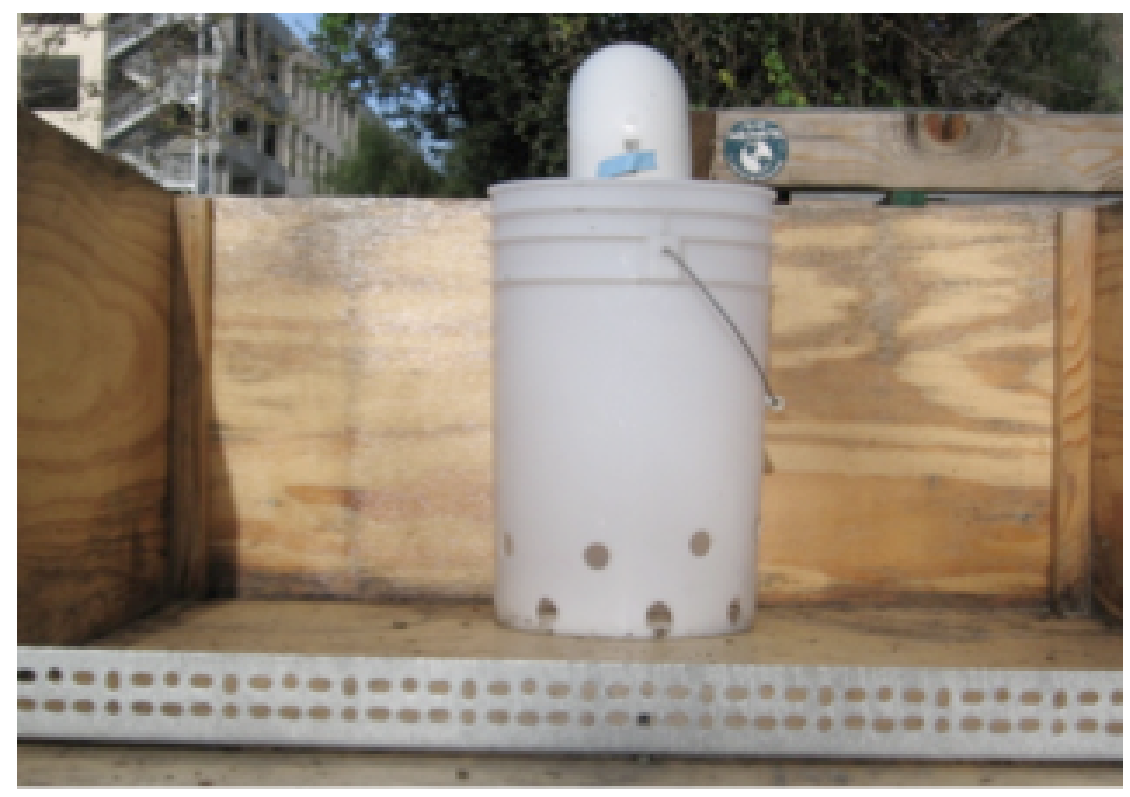

Figure 12. Mixing chamber and weir installed in test flume 


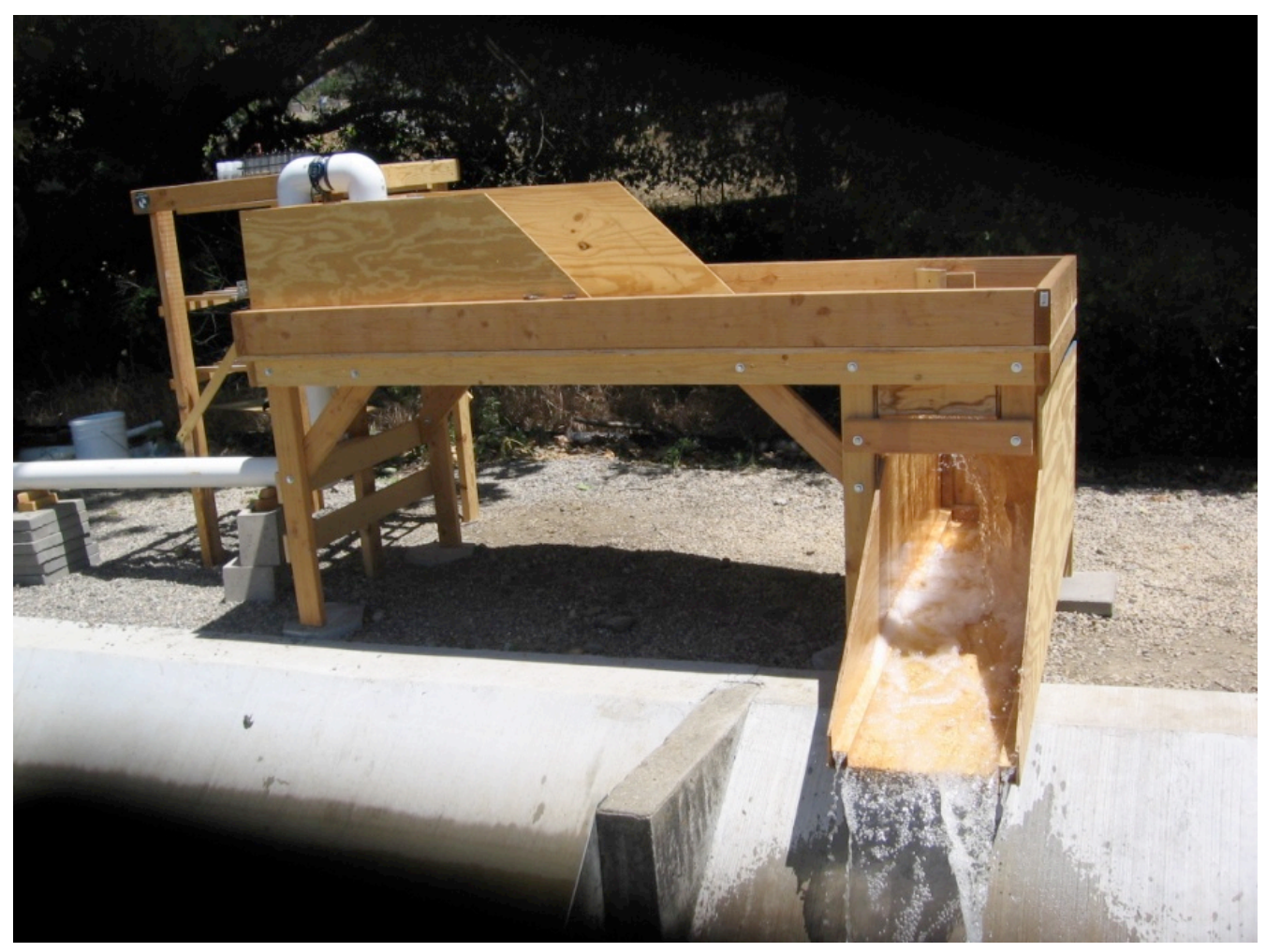

Figure 13. Opperation of test flume

\subsubsection{Clean Filter Head Loss Determination}

The filter head loss was tested with a clean filter using pond water as the only source of solids (about $50 \mathrm{mg} / \mathrm{L}$ total suspended solids). The head loss was measured at flow rates of $20,50,115,150,175$, and 200 GPM. Once the desired flow rate was reached, head loss measurements were taken by measuring distance from the bottom of the filter basket to the water surface level. The head loss measurements were taken approximately 15 seconds after steady flow was achieved to avoid excessive sediment buildup. This test was run one time. 


\subsubsection{Filter Loading Test at 200 GPM}

The filter was loaded at $200 \mathrm{GPM}$ at a suspended solids concentration of $80-100 \mathrm{mg} / \mathrm{L}$ to determine the amount of solids that would cause the filter to overflow at this flow rate (by passing the filter fabric and passing through the mesh screen). Since initial TSS tests indicated the pond water only contained $30-50 \mathrm{mg} / \mathrm{L}$ solids, additional solids were added to the mixing chamber as fine sand to provide an approximate concentration of 80-100 $\mathrm{mg} / \mathrm{L}$ solids. The sand was added to the mixing tank every 5 seconds in small, preweighed increments in order to achieve a steady loading. Head loss was measured at set times, and the solids loading was calculated based on known loadings. This test was run one time.

\subsubsection{Loaded Filter Head Loss Determination}

After the filter had been loaded with solids to the point where it was overflowing through the plastic mesh, additional head loss measurements were taken to determine how well a fully loaded filter could handle flow rates lower than the 200 GPM flow used in the previous test. The head loss in the loaded filter was measured at flow rates of 20 and 80 GPM. The filter overflowed when the flow rate was raised to $150 \mathrm{GPM}$. This test was run one time.

\subsubsection{Sediment Removal Efficiency Determination}

The suspended solids removal efficiency of the DrainPac ${ }^{\mathrm{TM}}$ filter was tested at 20, 60, 150, and 200 GPM. Table 3 below lists the flow rates and corresponding nominal velocities through the filter media. 
Table 3. Flow rates used in DrainPac ${ }^{\mathrm{TM}}$ testing

\begin{tabular}{|c|c|}
\hline Flow Rate (GPM) & Nominal Velocity (ft/sec) \\
\hline 20 & 0.013 \\
\hline 60 & 0.038 \\
\hline 150 & 0.097 \\
\hline 200 & 0.132 \\
\hline
\end{tabular}

The filter was thoroughly cleaned with tap water before testing at each flow rate.

Cleaning was done by reversing the filter and massaging the fabric under tap water. After cleaning, the filter was installed into the flume and the flow of sediment-laden water was started. Because the pond water only contained 30 to $50 \mathrm{mg} / \mathrm{L}$ solids, poorly graded sand with less than 5\% fines was added to the mixing chamber (Figure 14 and Table 4). For each test, 200 gallons of water were allowed to pass before samples were taken. Since the solids which build up in the bottom of the filter may affect removal efficiency, this uniform pre-loading was used for all tests at each flow rate. Three influent and three effluent samples were collected using 0.5-L plastic sample bottles for each test. Samples were analyzed for total suspended solids (TSS) following Standard Method \#2540 D (APHA, 1999b). Type G4 glass fiber filters (Fisher Scientific) with a nominal pore size of $1.2 \mu \mathrm{m}$ and a diameter of $42.5 \mathrm{~mm}$ were used. For each replicate, $0.5 \mathrm{~L}$ of water was filtered. The removal efficiency was calculated using the following equation:

$$
\text { Removal Efficieny }(\%)=\frac{\text { Influent Concentration }- \text { Effluent Concentration }}{\text { Influent Concentration }} \times 100
$$


Table 4. Sieve analysis of solids added to mixing chamber

\begin{tabular}{|c|c|c|c|c|}
\hline Sieve No. & Sieve Size $(\mathrm{mm})$ & Weight Retained (g) & \% Cumulative Retained & \% Passing \\
\hline 4 & 4.75 & 0 & 0.00 & 100.00 \\
\hline 10 & 2 & 0 & 0.00 & 100.00 \\
\hline 20 & 0.85 & 839.06 & 32.37 & 67.63 \\
\hline 40 & 0.425 & 1075.77 & 73.88 & 26.12 \\
\hline 60 & 0.25 & 431.66 & 90.53 & 9.47 \\
\hline 100 & 0.15 & 180.97 & 97.51 & 2.49 \\
\hline \multirow[t]{3}{*}{200} & 0.075 & 48.24 & 99.38 & 0.62 \\
\hline & $<0.075$ & 16.19 & 100 & \\
\hline & Total $=$ & 2591.89 & & \\
\hline
\end{tabular}

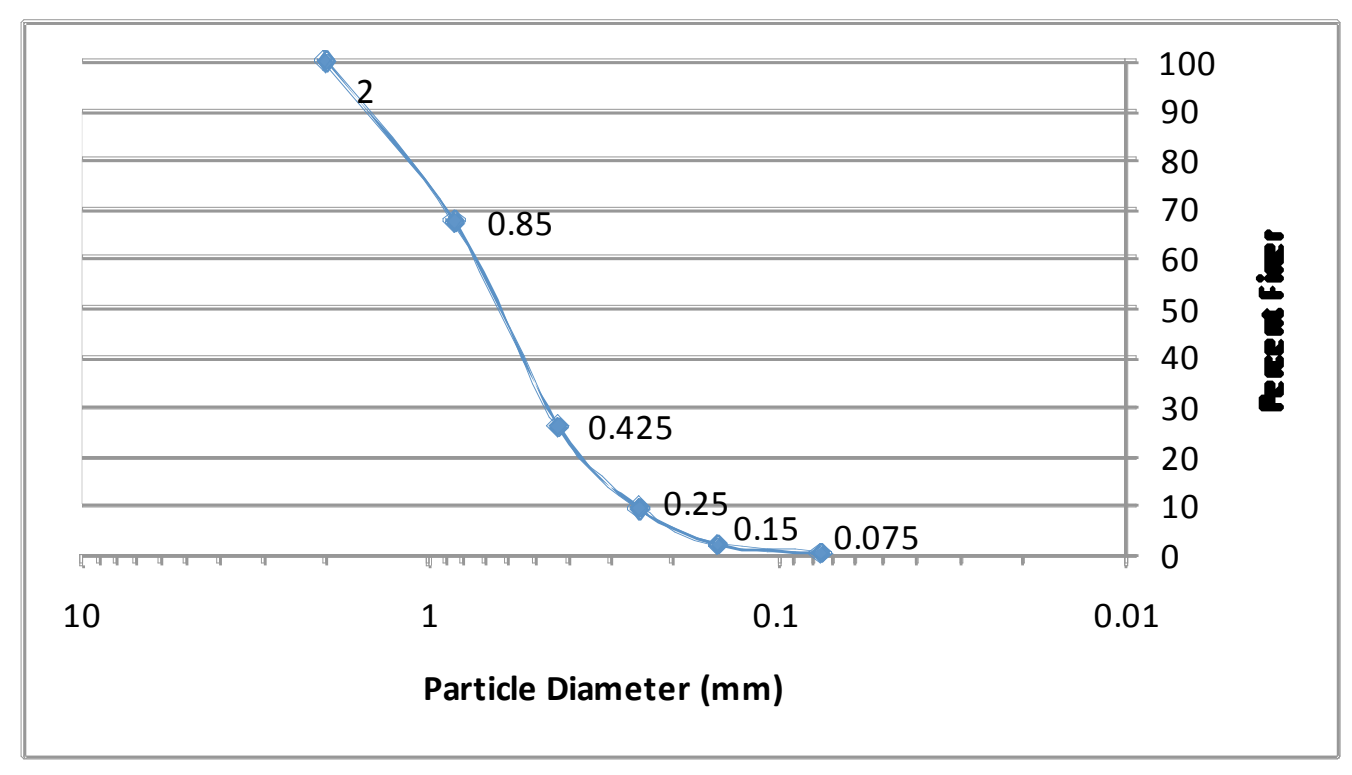

Figure 14. Sieve analysis of solids added to mixing chamber

\subsubsection{Oil Removal Efficiency Determination}

Oil removal efficiency was tested at flow rates of 20, 60, 150, and 200 GPM. Oil was pumped into the mixing chamber at 2.5, 7.6, 19.0, and $25.4 \mathrm{~mL} / \mathrm{sec}$, respectively, for each of the flow rates tested. This resulted in an influent oil concentration of approximately 30 $\mathrm{mg} / \mathrm{L}$. Because the effluent from the flume is discharged to a farm field, biodegradable vegetable oil was used to simulate oil and grease deposits found on streets and parking 
lots. Oil was added to the influent stream using a peristaltic pump (Cole Parmer, Naperville, Illinois). Before each test, the filter was thoroughly cleaned with tap water. For each flow rate tested, 200 gallons of oil-laden water were allowed to pass through the filter in order to maintain a uniform initial buildup of oil and pond sediment for each test. Each flow rate was tested one time.

Influent and effluent samples were analyzed for oil using a modified Standard Methods 5520 B Partition-Gravimetric Method (APHA, 1999a). In this method the oil is extracted into hexane and quantified gravimetrically after all the hexane has been evaporated. For the extractions, $2 \mathrm{~L}$ separatory funnels were used. $100 \mathrm{~mL}$ of sample was poured into the separatory funnel, $30 \mathrm{~mL}$ of hexane was added, and the funnel was shaken for 2 minutes. After 10 minutes of settling, the aqueous portion along with a small amount of the organic portion were drained back into the original sample container. The remaining organic portion was drained through approximately 10 grams of anhydrous sodium sulfate which was on top of a small amount of glass wool in a funnel. The hexane was collected into a thoroughly cleaned, dried, and weighed Zymark 200-mL TurboVap ${ }^{\circledR}$ vial. The aqueous portion was then subjected to the same separation routine two more times using $30 \mathrm{~mL}$ of hexane. $20 \mathrm{~mL}$ of hexane was then used to rinse the funnel of anhydrous sodium sulfate to remove any residual oils. The TurboVap ${ }^{\circledR}$ vial was then transferred to an automated Zymark TurboVap ${ }^{\circledR}$ concentrator (Caliper Lifesciences, Hopkinton, MA), which concentrated the extracts by evaporation with nitrogen, in a $35^{\circ} \mathrm{C}$ water bath. After all of the hexane had evaporated, the Turbovap ${ }^{\circledR}$ vial was weighed. The difference in weight represented the amount of oil present in the original sample. 


\subsubsection{Coliform Bacteria Removal Efficiency Determination}

Coliform bacteria removal efficiency was tested at flow rates of 20, 60, 150, and 200

GPM. Before each test, the filter was thoroughly cleaned with tap water. Samples were collected after 200 gallons of water had passed through the filter in order to maintain a uniform buildup of pond sediment for each test. Preliminary analysis indicated that the pond water contains sufficient ( $>2420 \mathrm{MPN} / 100 \mathrm{~mL}$ ) coliform bacteria for testing, so no additional bacteria were added. For each flow rate, three influent and three effluent samples were taken in sterile 0.5 -L plastic sample bottles. Samples were analyzed using the Colilert ${ }^{\circledR}$ method (Appendix A). The samples were diluted 10X with sterile DI water and placed in $100 \mathrm{~mL}$ Colilert ${ }^{\circledR}$ plastic containers. The Colilert $\AA$ reagent was added, and the bottles were shaken to dissolve the powder. The solution was then poured into an Idexx-brand Quantitray. The Quantitray was sealed using an Idexx-brand tray sealer, and placed in an incubator at $37 \mathrm{C}$ for 24 hours. During incubation, the tray wells with coliform bacteria present turn yellow. The tray wells which have E. coli bacteria present fluoresce when under UV light. Using an MPN table provided by Idexx, the MPN/100mL can be determined from the number of cells which turn yellow or fluoresce under UV light.

\subsection{N-halamine Brominated Biocidal Bead Testing in Laboratory Columns}

The N-halamine brominated biocidal beads were tested to determine how efficiently they inactivate bacteria from a stream of pond water. The N-halamine beads were first tested in the laboratory using a glass column, and then later tested in a full scale application in a 
DrainPac $^{\mathrm{TM}}$ stormwater filter. Initially beads with a diameter of $0.3 \mathrm{~mm}$ were tested, and then subsequently $0.8 \mathrm{~mm}$ diameter beads were used. Each test was conducted once.

\subsubsection{Testing Setup}

The testing apparatus was composed of a glass column with a 1-cm inside diameter. The column was capped at either end, and tubing was attached to convey the influent and effluent flows. The column was oriented for upward flow in order to minimize the effects of channeling. Glass wool was packed into the column on either side of the N-halamine beads to hold them in place (Figure 15). For the $0.3 \mathrm{~mm}$ beads, a mass of $0.62 \mathrm{~g}$ of beads equated to a bed depth of $1 \mathrm{~cm}$ in the column. For the $0.8 \mathrm{~mm}$ beads, the $1 \mathrm{~cm}$ bed depth was achieved with $0.55 \mathrm{~g}$. 


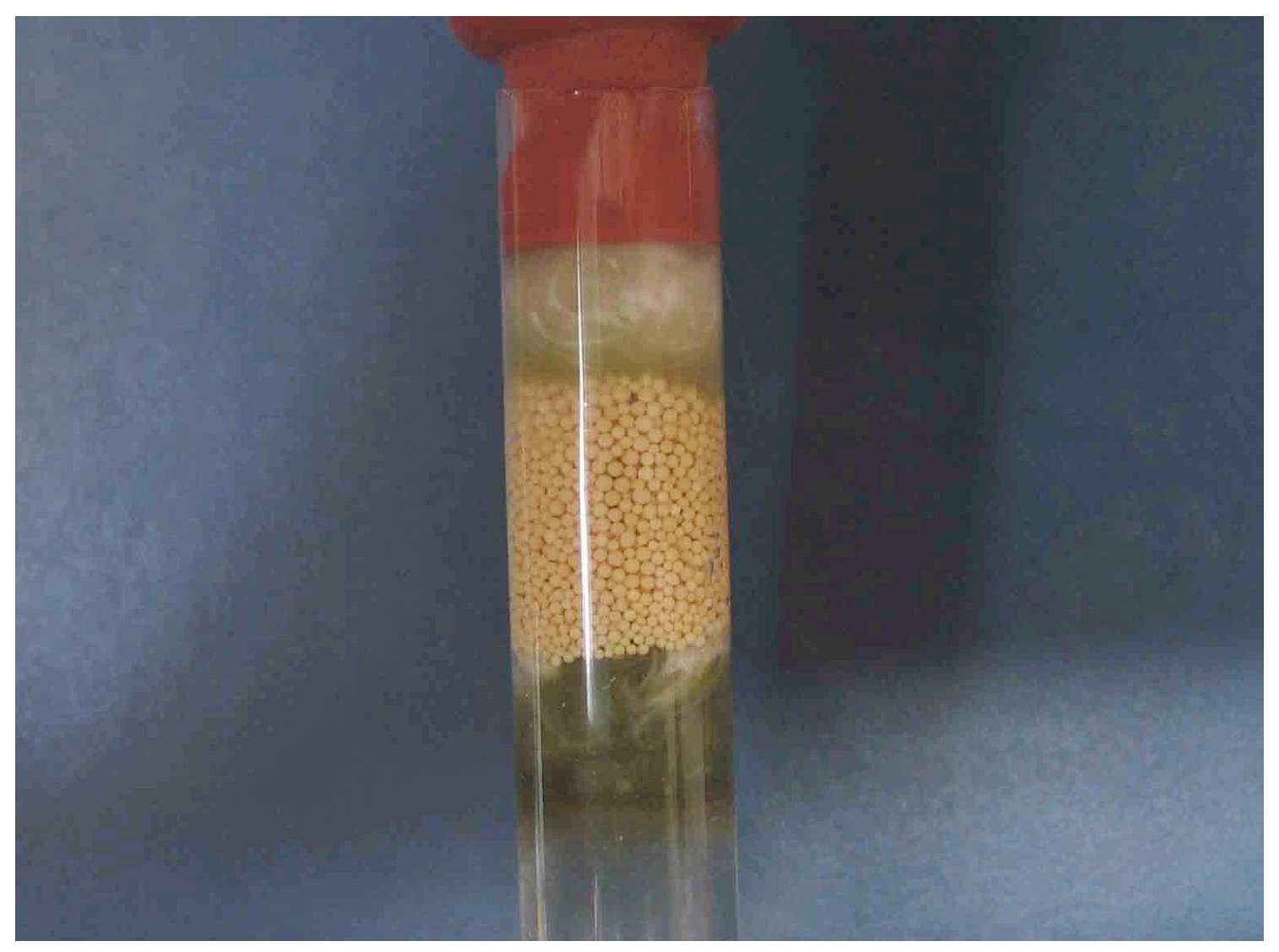

Figure 15. Glass column packed with $0.8 \mathrm{~mm}$ N-halamine beads.

\subsubsection{Head Loss Determination}

The first tests with the laboratory column were conducted to determine the amount of head loss across a 1-cm bed depth of N-halamine beads as a function of flow rate. To test the head loss of the beads, the basic bead testing apparatus was modified with a manometer as shown in Figure 16. Tests were conducted to determine the head loss through the column alone, through the column with just the glass wool, and through the column with the glass wool and beads. By doing this, it was possible to determine the amount of head loss which could be attributed solely to the beads by subtracting the head loss caused by the column with glass wool. 


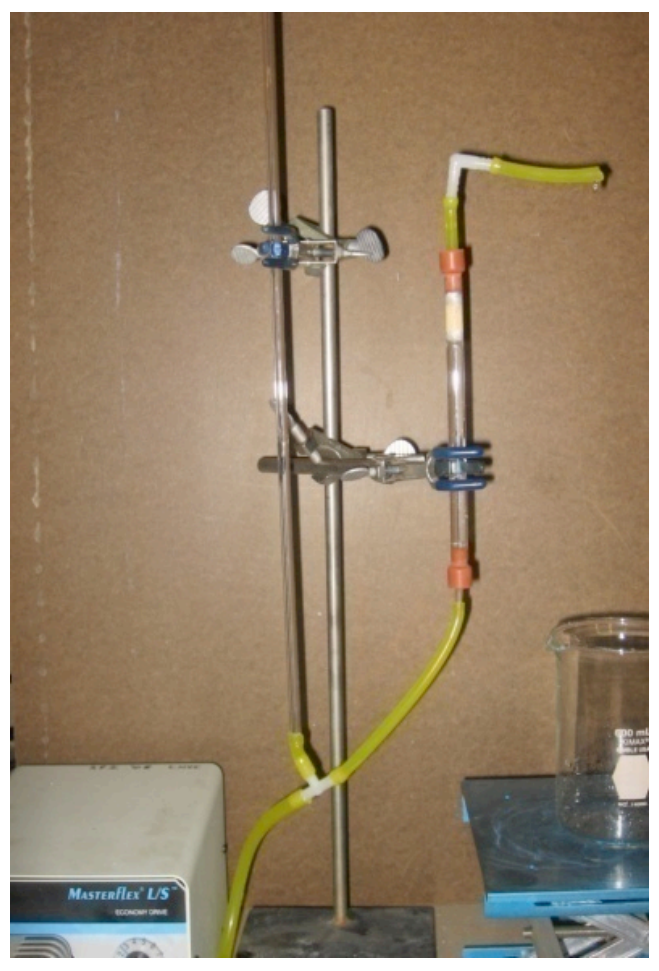

Figure 16. Column testing apparatus with manometer installed

For each of the three head loss measurements (column alone, column with glass wool, and column with glass wool and beads), the following testing procedure was used. First, water was pumped through the system until it was flushing through. The flow was then shut off, and the system was allowed to reach static equilibrium. At this point, the level on the manometer was marked and labeled as the datum. Next, water was pumped through the system at various flow rates. When the fluid level in the manometer had stabilized, the reading was marked. Flow rates of $0.28,0.56,0.84,1.12$, and $1.4 \mathrm{~mL} / \mathrm{sec}$ were tested. These flow rates were chosen in order to match the superficial velocities which would be present in the DrainPac ${ }^{\mathrm{TM}}$ filter at flow rates of $18,36,54,72$, and 90 GPM (Table 5). 
Table 5. Flow Rates Used in Head Loss Testing

\begin{tabular}{|c|c|c|}
\hline $\begin{array}{c}\text { Flow Rate in Column } \\
(\mathrm{mL} / \mathrm{sec})\end{array}$ & $\begin{array}{c}\text { Superficial } \\
\text { Velocity }(\mathrm{cm} / \mathrm{sec})\end{array}$ & $\begin{array}{c}\text { Equivelent Flow Rate in } \\
\text { DrainPac (GPM) }\end{array}$ \\
\hline 0.28 & 0.36 & 18 \\
\hline 0.56 & 0.71 & 36 \\
\hline 0.84 & 1.07 & 54 \\
\hline 1.12 & 1.42 & 72 \\
\hline 1.4 & 1.78 & 90 \\
\hline
\end{tabular}

\subsubsection{Quenching with Sodium Thiosulfate}

Because the beads release small amounts of bromine into the effluent water, tests were needed to determine whether the bacteria were being killed while passing through the packing of beads, or after leaving due to the residual bromine concentration. By adding sodium thiosulfate to the samples at predetermined times, the residual bromine could be "quenched", effectively stopping additional bacteria from being killed while the samples were transported and analyzed. The sodium thiosulfate was added to a concentration of $0.0133 \mathrm{~N}$. Three different "quenching” procedures were used, as described below.

Instantaneous Quenching - $40 \mathrm{~mL}$ of $0.04 \mathrm{~N}$ sodium thiosulfate was measured in a graduated cylinder. A sample of $80-\mathrm{mL}$ was collected directly into the cylinder containing the quenching solution. This effectively quenched the sample immediately, and therefore could be used to measure the amount of bacteria killed only while the water flowed through the beads. 
Quenching after sample collection - After $80 \mathrm{~mL}$ of sample was collected into a graduated cylinder, $40 \mathrm{~mL}$ of $0.04 \mathrm{~N}$ sodium thiosulfate was added. The times required for sample collection at $0.28 \mathrm{~mL} / \mathrm{sec}, 0.56 \mathrm{~mL} / \mathrm{sec}$, and $0.84 \mathrm{~mL} / \mathrm{sec}$ were approximately 95 seconds, 145 seconds, and 285 seconds. This test served as an intermediate between the instant and 10 minute quenching.

10 minute delay - The $80 \mathrm{~mL}$ sample was quenched with $40 \mathrm{~mL}$ of $0.04 \mathrm{~N}$ sodium thiosulfate 10 minutes after the sample was collected. This test served to indicate the effect of the residual bromine released into the effluent.

The samples were collected and transported in glass bottles which were cleaned and disinfected with bleach between tests, and analyzed using the EPA approved standard method for coliform testing. This method uses Colilert ${ }^{\circledR}$ selective media and Quantitrays, as described above. Samples of $100-\mathrm{mL}$ are required to conduct the Colilert ${ }^{\circledR}$ test. This sample was either composed entirely of raw sample, or it was diluted with sterile DI water to ensure that the test returns results within the readable range ( 0 to 2419.6 MPN/100 mL). The Colilert reagent contains sufficient buffering properties to prevent the DI water from killing bacterial cells. The samples were analyzed using the Colilert ${ }^{\circledR}$ test described in Section 3.1.7. above. 


\subsubsection{Testing with Pond Water in DrainPac ${ }^{\mathrm{TM}}$ Filter Conditions}

The first tests of the N-halamine beads were conducted using a $1 \mathrm{~cm}$ thickness of beads, and flow rates of $0.28,0.56$ and $0.84 \mathrm{~mL} / \mathrm{sec}$. These flow rates corresponded to flow rates of 18, 36, and 54 GPM in the DrainPac ${ }^{\mathrm{TM}}$ filter (Table 5). For these tests, pond water was used as the source of bacteria. $80 \mathrm{~mL}$ samples were collected and quenched as described in Section 3.2.3.

\subsubsection{Testing with Lab-Grown $E$. coli Strain K-12}

The next tests were conducted as a comparison to the study by Chen et al. in 2003. This test was conducted with significantly higher bacteria concentrations. In a field application, the N-halamine beads would need to be able to handle an occasional spike in the bacterial loading. This could occur due to spills, pets (dog walking), livestock (for example at a parade) or other reasons. In order to test the ability of the N-halamine beads to handle very high loads of bacteria, a culture needed to be grown in the lab.

Escherichia coli (E. coli) strain K-12 was chosen as the strain to be grown to challenge the N-halamine beads. The culture was obtained from the Cal Poly, San Luis Obispo Biological Sciences Department. First, the broth was prepared by adding $25 \mathrm{~g}$ of powdered LB medium to $1 \mathrm{~L}$ of DI water. The LB medium was also obtained from the Cal Poly, San Luis Obispo Biological Sciences Department. This solution was then placed in an Erlenmeyer flask and autoclaved. After the broth had cooled sufficiently, it was inoculated with $E$. coli using a disposable sterile glass inoculating loop. The broth was then placed in a shaking incubator at $37 \mathrm{C}$ for 24 hours. 
After the culture had finished growing, $1.5 \mathrm{~mL}$ of broth was added to $1 \mathrm{~L}$ of sterile phosphate-buffered saline solution. The glass column was packed with a 1-cm thickness of $0.3 \mathrm{~mm}$ diameter beads $(0.62 \mathrm{~g})$ and the $E$. coli suspension was pumped through at a flow rate of $0.28 \mathrm{~mL} / \mathrm{sec}$. Samples were collected and quenched using the quenching methods described above. After quenching, the samples were analyzed using the Colilert ${ }^{\circledR}$ test.

\subsubsection{Longevity Testing}

In a storm drain filter application, the N-halamine beads would need to maintain their biocidal effectiveness over long periods of time, and after multiple loadings. The beads are usually stored in sealed bags in the refrigerator, but the conditions in the field would be much different. Exposure to warmer temperatures, circulating air, and water may reduce the lifespan of the beads. In order to estimate how long the N-halamine beads could perform in an actual field application, longevity tests were conducted using the 0.3 mm beads.

The first longevity test was designed to determine whether the N-halamine beads maintain their disinfecting ting abilities after being exposed to ambient conditions for long periods of time. In the field, this would equate to the bead's ability to inactivate bacteria washed into a storm drain from a springtime shower after months without rain. To test this, a sample of beads was placed on a filter paper and wetted down with DI water. The filter paper was then folded to contain the beads, placed in a beaker, and allowed to sit in ambient conditions in the lab for over 5 months (162 days). After this 
time, $0.62 \mathrm{~g}$ of the beads were packed in the column and tested using a $0.56 \mathrm{~mL} / \mathrm{sec}$ flow of pond water. Samples were collected and quenched using the three quenching methods described above, and analyzed using the Colilert ${ }^{\circledR}$ test.

The second longevity test was designed to determine how well the beads could stand up to multiple storm events if placed in the DrainPac ${ }^{\mathrm{TM}}$ filter insert. For this test, wet/dry cycles were simulated in the lab. The column was packed with $0.62 \mathrm{~g}$ of $0.3 \mathrm{~mm}$ diameter beads, held in place with glass wool. In order to prevent the beads and wool in the column from becoming fouled with solids from the pond water, a pre-filter was constructed and placed inline before the packed column. The pre-filter was composed of a glass column packed with glass wool to a thickness of approximately $2 \mathrm{~cm}$. The glass wool in the pre-filter was replaced after each loading cycle. For this test, storm events were simulated by a flow of $0.56 \mathrm{~mL} / \mathrm{sec}$ (the equivalent of 36 GPM in the DrainPac ${ }^{\mathrm{TM}}$ filter) for a duration of one hour. After one hour, the flow was shut off and air was pumped through the column using a small fish tank air pump. This was done in order to ensure that the beads had completely dried before the next loading cycle (at least 24 hours later). Samples were collected and analyzed after the fifth loading cycle. The influent samples were collected after the pre-filter in order to take into account any bacteria that it may have removed.

\subsubsection{Control Test using Beads not activated with Bromine}

In order to accurately determine how effectively the N-halamine beads were inactivating bacteria, a control test needed to be conducted. This test was conducted in order to 
determine how much bacteria was getting filtered out by the glass wool as it passed through the column, and to test our methods.

The glass column was packed with the same weight $(0.62 \mathrm{~g}$ for $0.3 \mathrm{~mm}$ and $0.55 \mathrm{~g}$ for 0.8 $\mathrm{mm}$ ) of beads as in the experimental runs, and using the same thickness of glass wool. Pond water was passed through the column at $0.56 \mathrm{~mL} / \mathrm{sec}$ (the equivalent of $20 \mathrm{GPM}$ passing through the DrainPac ${ }^{\mathrm{TM}}$ filter). The influent and effluent were analyzed using the Colilert ${ }^{\circledR}$ method, and the quenching methods described above.

\subsection{Full-Scale Testing of $\mathrm{N}$-halamine Beads in the DrainPac ${ }^{\mathrm{TM}}$ Filter}

United Stormwater constructed two quilted sleeves containing N-halamine beads. Each sleeve had seven compartments, with each compartment containing 100 grams of $\mathrm{N}$ halamine beads ( $0.8 \mathrm{~mm}$ diameter). The sleeves were constructed of the same felt material as the filtration media of the DrainPac ${ }^{\mathrm{TM}}$ filter (Figure 17). 

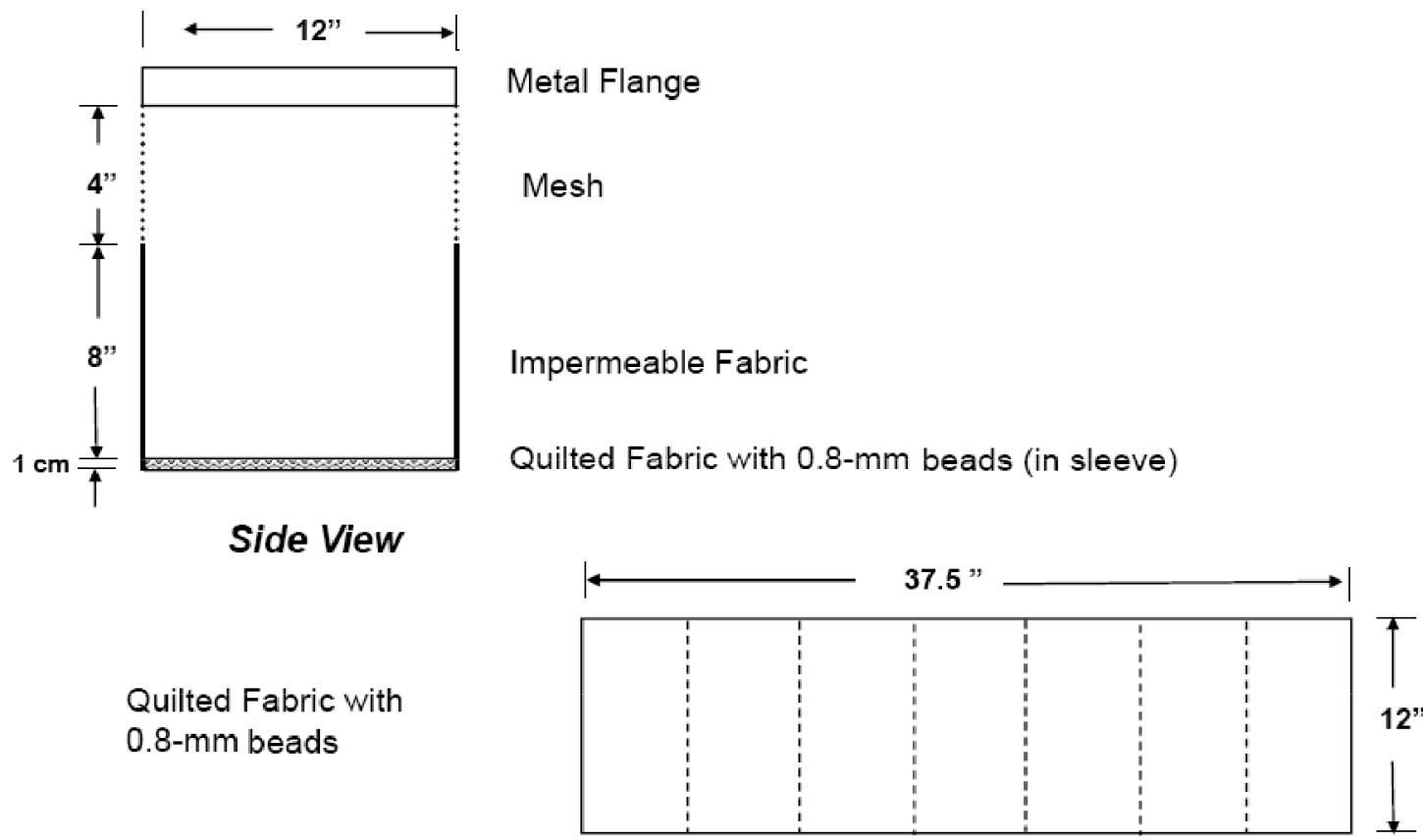

Top View

Figure 17. Design of Full Scale N-halamine Bead Testing in DrainPac ${ }^{\mathrm{TM}}$ Filter

United Stormwater constructed a custom DrainPac ${ }^{\mathrm{TM}}$ filter insert for use in the full scale tests. The unit was constructed such that the walls of the hanging filter basket were composed of a waterproof material. This was done to direct all of the entering water through the N-halamine beads. The two sleeves were layered into the filter basket such that the seams of the two sleeves were staggered. The filter basket was then placed in the test flume. 
The feed water for this experiment was primarily composed of pond water gravity fed at a flow rate of 36 gallons per minute from the on-campus pond. To obtain a reasonably high coliform concentration in the influent stream, the water was supplemented with a small addition of swine wastewater. The swine wastewater, obtained from another oncampus treatment pond, was pumped into the mixing chamber at a flow rate of 6.8 $\mathrm{mL} / \mathrm{min}$.

Prior to testing, the filter was flushed with 50 gallons of pond water. After a steady flow rate of 36 gallons per minute was established, triplicate influent and effluent samples were collected. The samples were quenched using four different regimes. The samples were quenched after 30 seconds, 2 minutes and 10 minutes by transfering the sample to a sterile $100 \mathrm{~mL}$ bottle containing the sodium thiosulfate tablet. After quenching, the samples were analyzed for total coliform bacteria using the method previously described. 


\section{CHAPTER 4: RESULTS AND DISCUSSION}

\subsection{DrainPac'M Filter Results}

This section outlines the results of testing the DrainPac ${ }^{\mathrm{TM}}$ filter for head loss, solids removal, oil removal, and bacteria removal.

\subsubsection{Clean Filter Head Loss}

The head loss through a clean DrainPac ${ }^{\mathrm{TM}}$ varied from $0.5 \mathrm{~cm}$ at $20 \mathrm{GPM}$ to $9.1 \mathrm{~cm}$ at 200 GPM (Table 6 and Figure 18). The DrainPac ${ }^{\text {TM }}$ filter presents very little head loss when it is not loaded with sediment. The cloth material seems to have very little resistance. Even with 200 GPM of pond water passing through the filter, the head loss was barely over $9 \mathrm{~cm}$. The filter has the capacity to handle about $17 \mathrm{~cm}$ of head loss before the flow bypasses the filter material and passes through the plastic mesh panel.

With no sediment in the filter, flow rates of well over 200 GPM could be filtered without bypassing the cloth.

Table 6. Clean filter head loss as a function of flow rate

\begin{tabular}{|c|c|}
\hline Flow (GPM) & Head Loss (cm) \\
\hline 20 & 0.5 \\
\hline 50 & 2.8 \\
\hline 80 & 3.8 \\
\hline 115 & 4.9 \\
\hline 150 & 5.5 \\
\hline 175 & 8.5 \\
\hline 200 & 9.1 \\
\hline
\end{tabular}




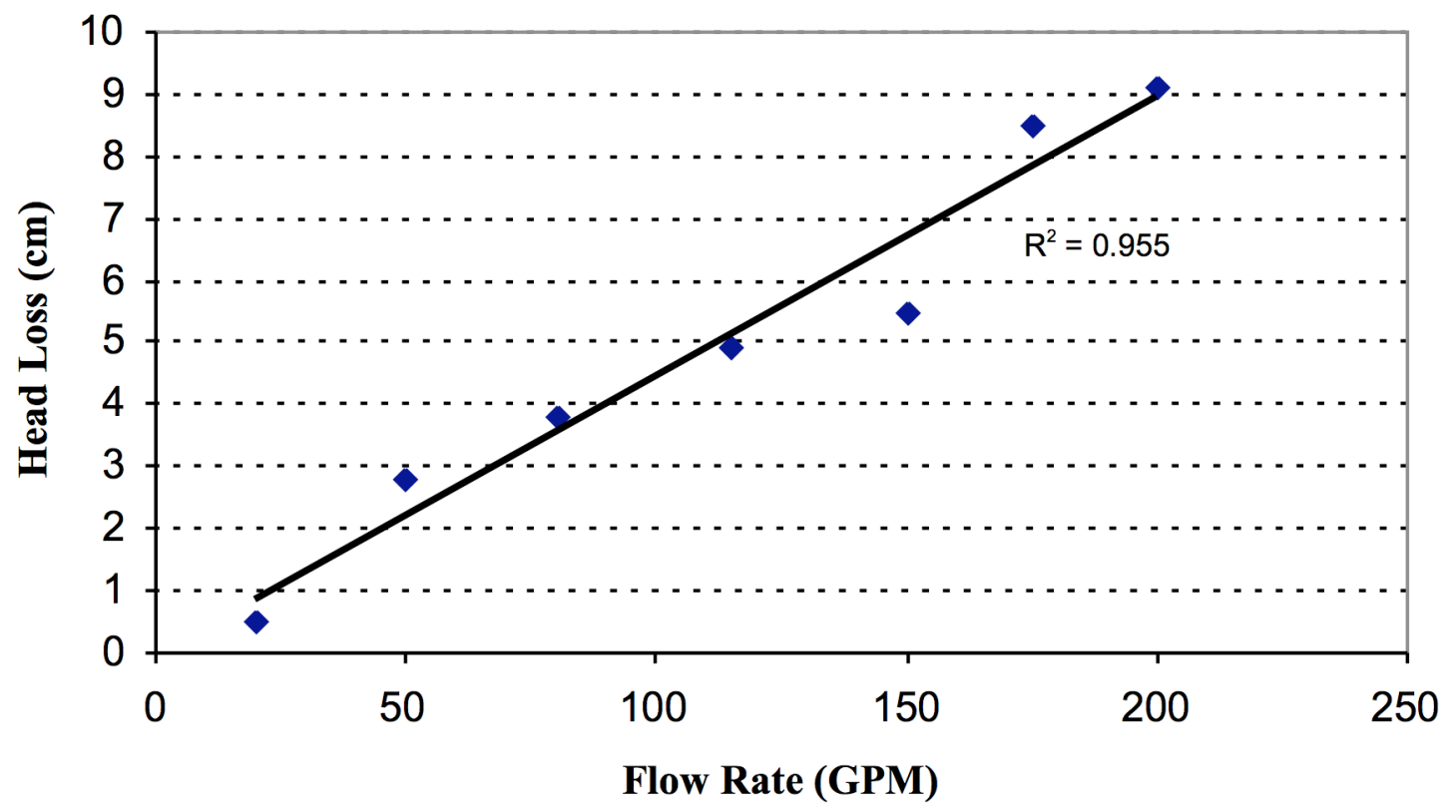

Figure 18. Clean filter head loss as a function of flow rate

\subsubsection{Filter Loading at 200 GPM}

The total amount of solids that caused the filter to overflow (greater than $17 \mathrm{~cm}$ head loss) at 200 GPM was 625 grams. When 625 grams of solids had been loaded, the head loss was measured as $21.5 \mathrm{~cm}$, which is above the $17 \mathrm{~cm}$ limit of the filter (Table 7 and Figure 19). As the solids were loaded to the filter, the head loss increased. The head loss proved to be related to the amount of solids in the filter by a linear function (Figure 19; $\mathrm{R}^{2}=0.9835$ ). The first measurement was taken after $147 \mathrm{~g}$ of solids had been loaded to the filter, and a head loss of $8 \mathrm{~cm}$ was measured. 
Table 7. Filter Loading at 200 GPM

\begin{tabular}{|c|c|}
\hline Head Loss (cm) at 200 gpm & Total Filter Loading (g) \\
\hline 8.0 & 147 \\
\hline 11.5 & 269 \\
\hline 13.8 & 378 \\
\hline 16.7 & 511 \\
\hline 21.5 (overflow) & 625 \\
\hline
\end{tabular}

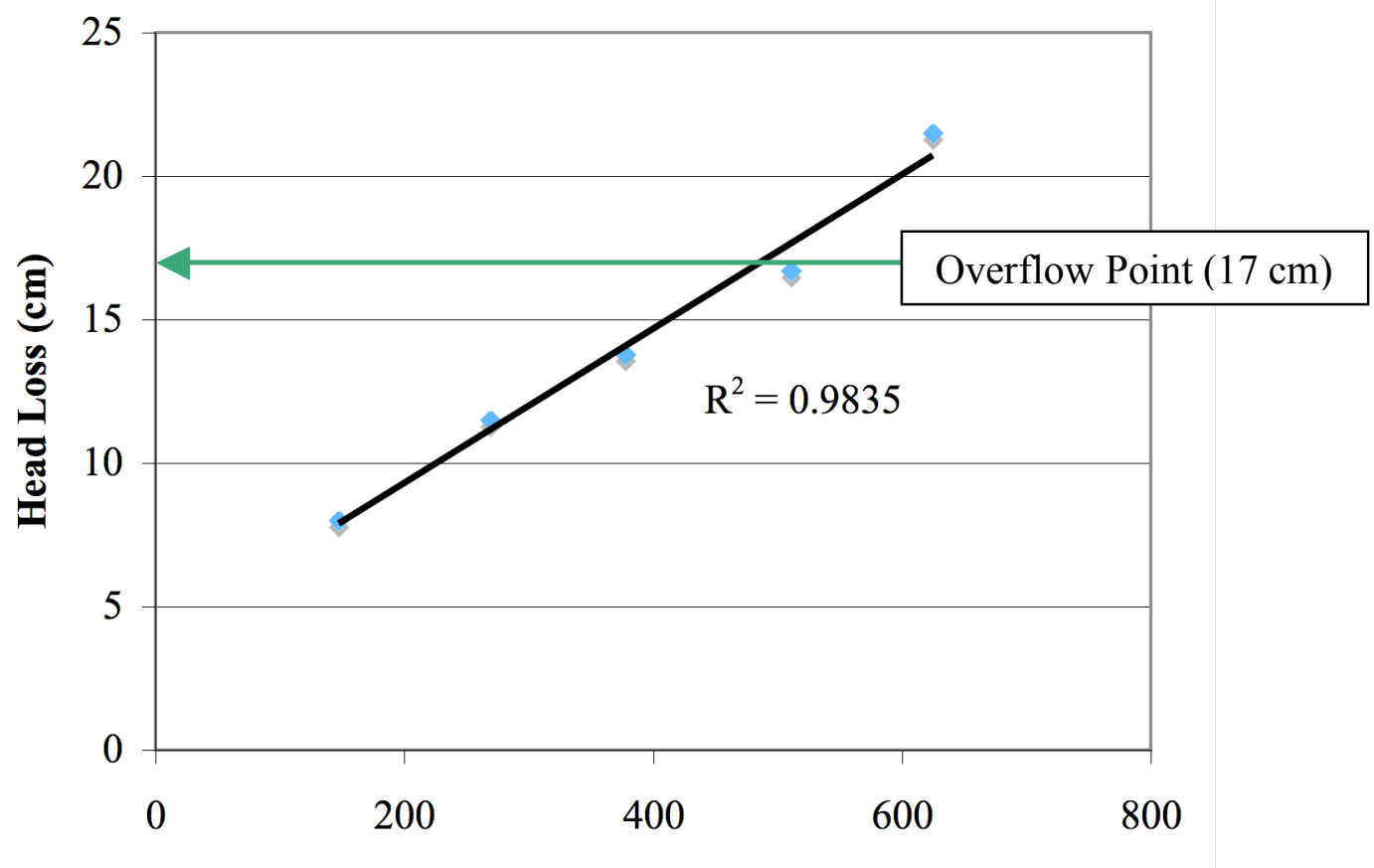

Filter Loading (g)

Figure 19. Head losses through the DrainPac ${ }^{\mathrm{TM}}$ filter as a function of solids loading at 200 GPM. 


\subsubsection{Loaded Filter Head Loss}

As would be expected, the head loss through the filter was much higher after it had been loaded with solids to the point of failure (overflow) at a flow of 200 GPM. Head losses for the filter loaded with $625 \mathrm{~g}$ of solids were significantly higher than those measured for the clean filters, with $8.5 \mathrm{~cm}$ and $17.5 \mathrm{~cm}$ head losses at 20 and $80 \mathrm{GPM}$, respectively.

\subsubsection{Sediment Removal Efficiency}

Sediment removal efficiencies are reported in Table 8 as the average of the removal efficiencies calculated from each of three replicate samples. The DrainPac ${ }^{\mathrm{TM}}$ filter removed between $83 \%$ and $91 \%$ of suspended solids over flow rates from 20 to 200 GPM. Removal efficiency decreased slightly with increasing flow rate, but this trend was not statistically significant (see standard deviations in Table 8 and error bars in Figure 20). By visual inspection of the sediment accumulated in the bottom of The DrainPac ${ }^{\mathrm{TM}}$ filter, it is apparent that the insert is effective at removing larger, grit sized particles, as well as flocs of organic material, such as algae. The particles can be observed as a scum/grit layer in the filter after a test run.

Solids removal efficiencies observed in this study were slightly lower than those observed previously in an earlier study conducted at UCLA which reported solids removal efficiencies ranging from $95 \%$ to $98 \%$ at a test flow rate of 75 GPM (Stenstrom, 1998). The UCLA study used trash, with large debris particles, while the current study used fine suspended solids in the pond water and fine sand. This difference in particle size provides a likely explanation for the greater removal efficiency observed in the 
UCLA study because large, bulky solids are expected to be much more easily removed by filtration than the fine sand and silt particles used in the current study.

Table 8. Solids Removal Efficiency of the DrainPac ${ }^{\mathrm{TM}}$ Filter

\begin{tabular}{|c|c|c|}
\hline $\begin{array}{c}\text { Flow Rate } \\
\text { (GPM) }\end{array}$ & $\begin{array}{c}\text { Average Removal } \\
\text { Efficiency (\%) }\end{array}$ & Standard Deviation \\
\hline 20 & 90 & 1.3 \\
\hline 60 & 89 & 8.8 \\
\hline 150 & 83 & 10.9 \\
\hline 200 & 83 & 10.5 \\
\hline
\end{tabular}

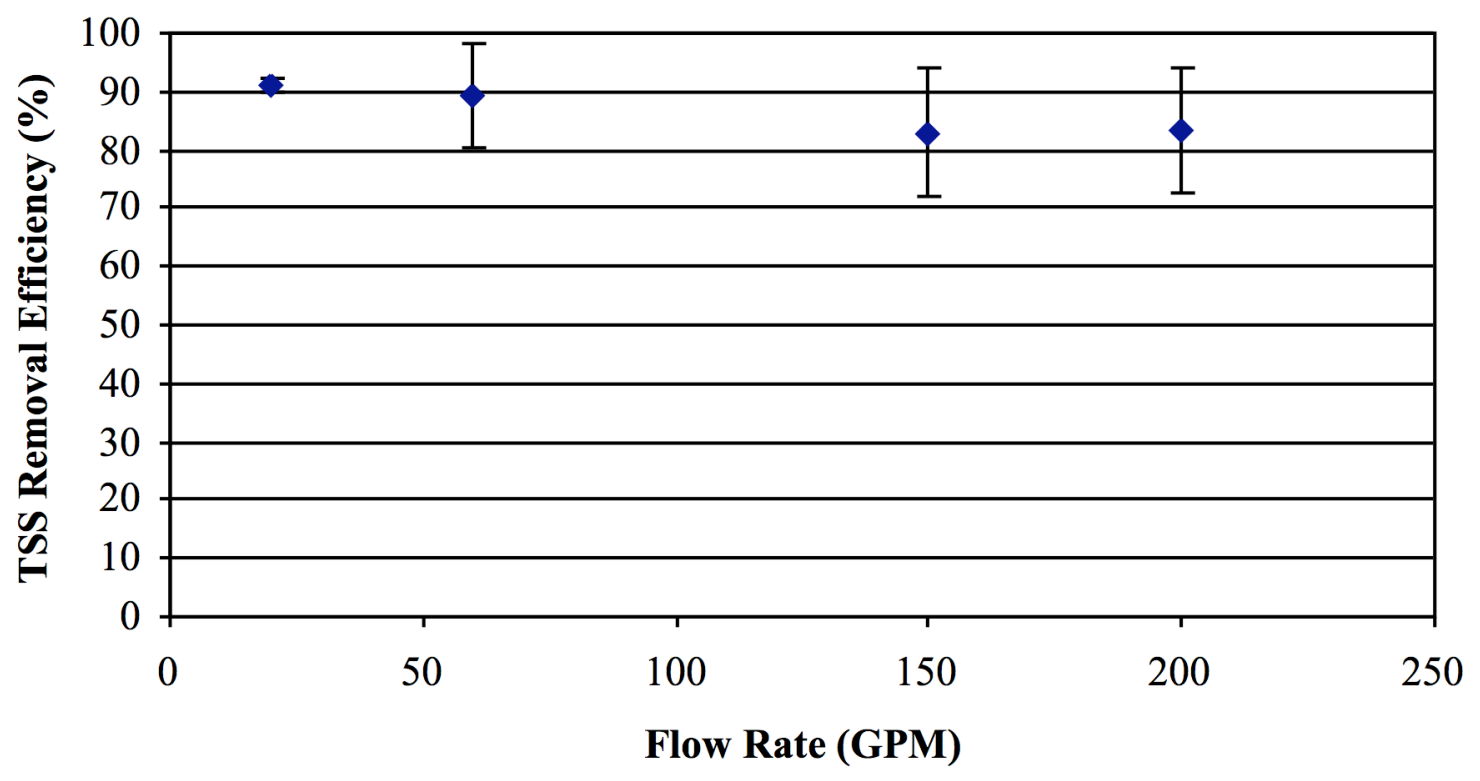

Figure 20. TSS removal efficiency as a function of flow rate in the DrainPac ${ }^{\mathrm{TM}}$ filter 


\subsubsection{Oil Removal Efficiency}

The oil removal efficiency varied between 40 and $82 \%$ (Table 9) for flow rates from 20 to 200 GPM. High variability in oil removal efficiencies was observed due to simple experimental variability, such as differences in prior solids loadings. There was no apparent trend of oil removal efficiency with flow rate in the present study. Similar removal efficiencies ( $49 \%$ to $86 \%$ ) were reported in a previous UCLA study of DrainPac $^{\text {TM }}$ filters (Stenstrom, 1998).

Table 9. Oil removal efficiency in the DrainPac ${ }^{\mathrm{TM}}$ filter as a function of flow rate

\begin{tabular}{|c|c|c|}
\hline $\begin{array}{c}\text { Flow Rate } \\
\text { (GPM) }\end{array}$ & $\begin{array}{c}\text { Average Removal Efficiency } \\
(\%)\end{array}$ & $\begin{array}{c}\text { Standard } \\
\text { Deviation }\end{array}$ \\
\hline 20 & 49 & 9.7 \\
\hline 60 & 68 & 18.7 \\
\hline 150 & 40 & 18.1 \\
\hline 200 & 82 & 7.7 \\
\hline
\end{tabular}

\subsubsection{Coliform Bacteria Removal Efficiency}

As expected, no reductions in coliform bacteria concentrations were observed by passing through the DrainPac ${ }^{\mathrm{TM}}$ filter at any flow rate tested (Table 10). At 20 GPM, the effluent coliform counts actually appeared to be higher than the influent concentrations, and at the higher flow rates differences between the influent and effluent coliform counts were within the observed standard deviations, as shown in Table 10. These results show no evidence that the DrainPac ${ }^{\mathrm{TM}}$ filter removes coliform bacteria under the conditions tested. It is clear that the size of the pores and openings in the fabric of the DrainPac ${ }^{\mathrm{TM}}$ filter 
insert are far too large to trap significant amounts of bacteria. It is possible that a DrainPac $^{\mathrm{TM}}$ filter which has been loaded with solids may remove bacteria more efficiently due to the presence of a filter cake, but this was not tested.

Table 10. Results of bacteria inactivation testing with the DrainPac ${ }^{\mathrm{TM}}$ filter

\begin{tabular}{|c|c|c|}
\hline \multirow{2}{*}{$\begin{array}{c}\text { Flow Rate } \\
\text { (GPM) }\end{array}$} & \multicolumn{2}{|c|}{$\begin{array}{c}\text { Coliform Bacteria Concentration } \\
\text { (MPN/100 mL)* }\end{array}$} \\
\cline { 2 - 3 } & Influent & Effluent \\
\hline 20 & $1930(430)$ & $3420(620)$ \\
\hline 80 & $2560(450)$ & $2670(220)$ \\
\hline 150 & $2500(700)$ & $2680(860)$ \\
\hline 200 & $2270(410)$ & $2780(410)$ \\
\hline
\end{tabular}

* Average of triplicate samples; standard deviations in parentheses

\subsection{Results of Laboratory-Scale Testing of N-halamine Beads}

This section outlines the results of laboratory-scale testing of N-halamine brominated biocidal beads using glass columns. The results of full scale testing of N-halamine beads in the DrainPac ${ }^{\mathrm{TM}}$ filter application are given in Section 4.3.

\subsubsection{Head Loss}

In laboratory columns, the N-halamine beads created a significant amount of head loss due to their small size and low void volume when packed in a column. A linear relationship was observed between the flow rate and the head loss through the beads (Figure 22 and Figure 24). The head loss of the column alone was minimal, varying between 0.8 and $1.5 \mathrm{~cm}$ (Table 11, Table 12 and Figure 21). The addition of glass wool creates a significant increase in head loss through the system (Table 11, Table 12, and Figure 21). The head losses due to different components of the system for the $0.3 \mathrm{~mm}$ 
beads are shown in Table 11, and the head losses expected from the beads alone were calculated by subtracting the head losses of the system components. The head loss from the 1-cm of packed beads ranged from 19 to $51.7 \mathrm{~cm}$ at flow rates selected to match nominal face velocities in the DrainPac ${ }^{\mathrm{TM}}$ of 18 to 90 cubic feet per minute. Since the standard DrainPac ${ }^{\mathrm{TM}}$ overflows at $17 \mathrm{~cm}$, these head losses would be unacceptable. To overcome this limitation, larger beads were tested. Head loss experiments were conducted one time for each bead diameter.

Table 11. Head loss through a packed column of $0.3 \mathrm{~mm}$ beads

\begin{tabular}{|c|c|c|c|c|c|}
\hline \multirow[b]{2}{*}{$\begin{array}{l}\text { Flow Rate } \\
(\mathrm{mL} / \mathbf{s e c})\end{array}$} & \multirow[b]{2}{*}{$\begin{array}{c}\text { Equivalent } \\
\text { Flow Rate in } \\
\text { DrainPac } \\
\text { Filter (GPM) }\end{array}$} & \multicolumn{4}{|c|}{ Head Loss (cm) } \\
\hline & & $\begin{array}{c}\text { Column } \\
\text { Alone }\end{array}$ & $\begin{array}{c}\text { Column with Glass } \\
\text { Wool }\end{array}$ & $\begin{array}{l}\text { Column, } \\
\text { Glass } \\
\text { Wool, } \\
\text { and } 1 \mathrm{~cm} \\
\text { of Beads }\end{array}$ & $\begin{array}{l}\text { Beads } \\
\text { Alone }\end{array}$ \\
\hline 0.28 & 18 & 0.8 & 11.0 & 30.0 & 19.0 \\
\hline 0.56 & 36 & 0.9 & 17.2 & 48.0 & 30.8 \\
\hline 0.84 & 54 & 1.1 & 28.0 & 64.0 & 36.0 \\
\hline 1.12 & 72 & 1.3 & 35.0 & 80.5 & 45.5 \\
\hline 1.4 & 90 & 1.5 & 42.5 & 94.2 & 51.7 \\
\hline
\end{tabular}




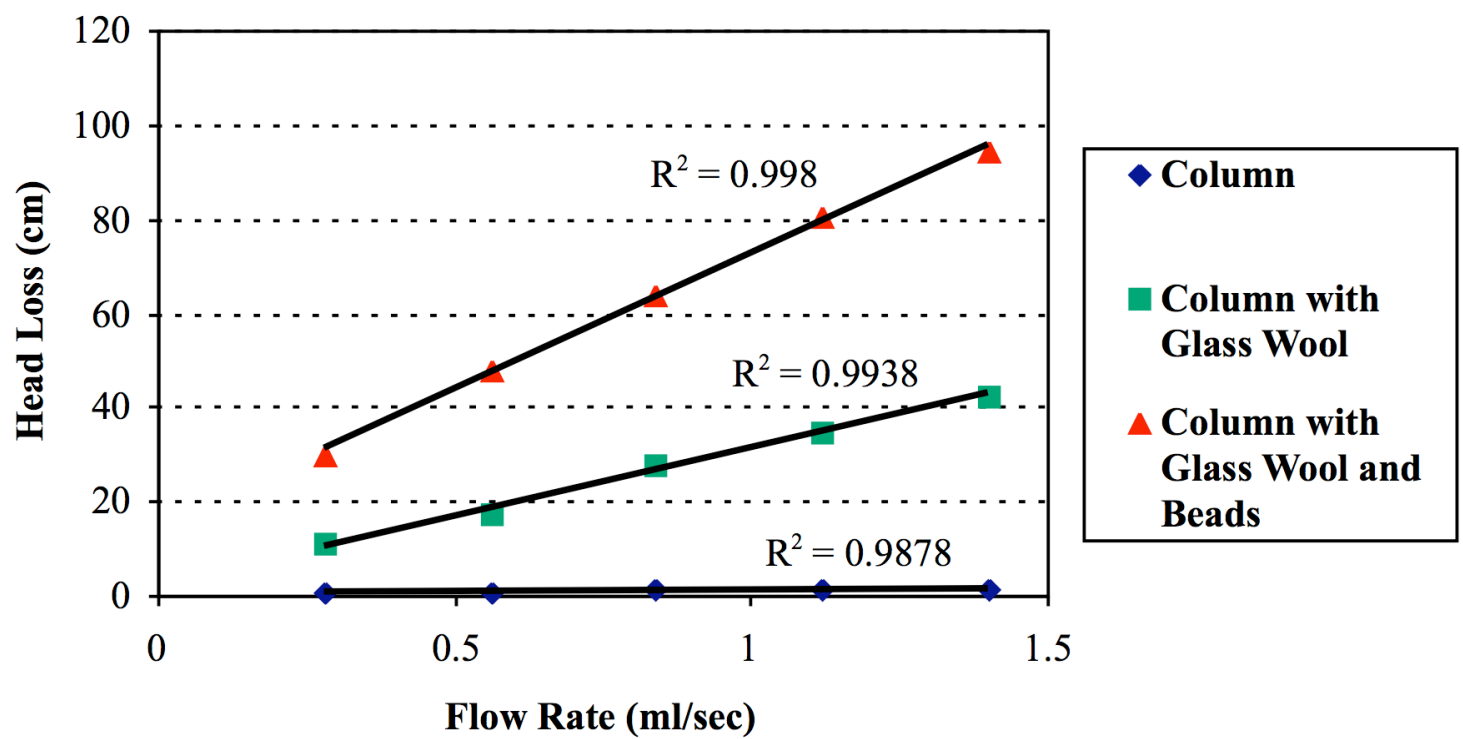

Figure 21. Head losses through the column system and $0.3 \mathrm{~mm}$ N-halamine beads

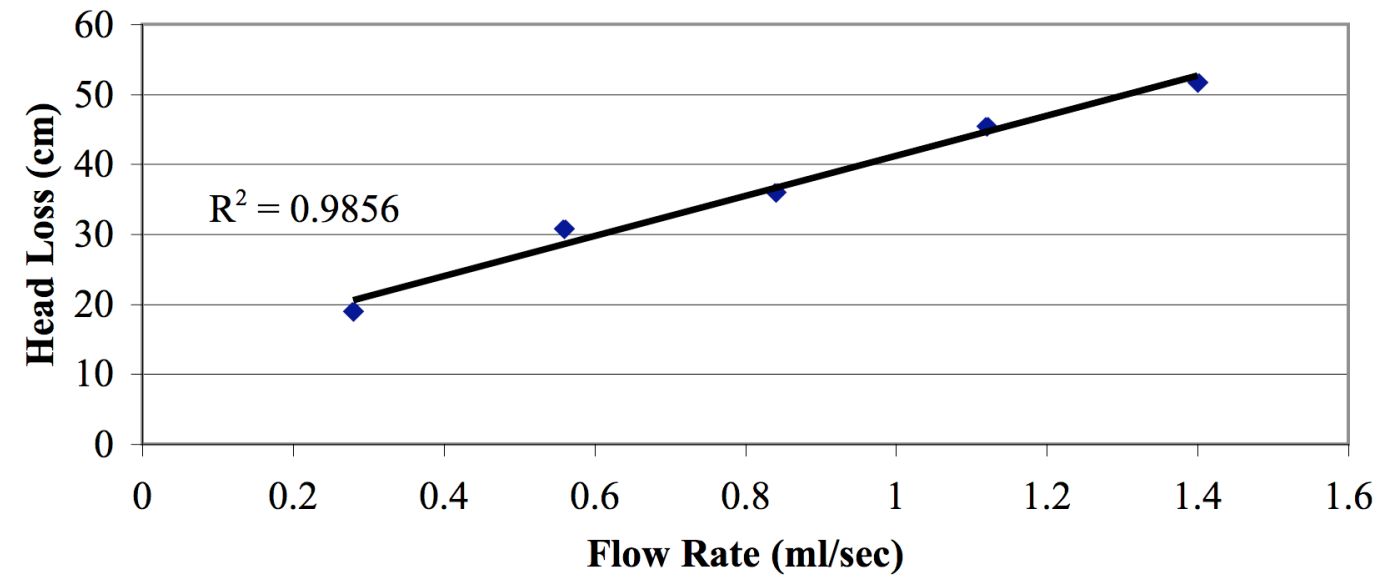

Figure 22. Head loss through $0.3 \mathrm{~mm}$ beads alone. 
The $0.8 \mathrm{~mm}$ beads packed in laboratory columns produced head losses from 11.9 to 47.7 $\mathrm{cm}$ at flow rates between $0.28 \mathrm{~mL} / \mathrm{sec}$ and $1.4 \mathrm{~mL} / \mathrm{sec}$ (Table 12 and Figure 23). As would be expected, water passes more easily though a column packed with the $0.8 \mathrm{~mm}$ beads than with the same depth of $0.3 \mathrm{~mm}$ beads. This difference is due to the difference in porosity.

Table 12. Head loss through a packed column of $0.8 \mathrm{~mm}$ beads.

\begin{tabular}{|c|c|c|c|c|c|}
\cline { 3 - 6 } \multicolumn{2}{c|}{} & $\begin{array}{c}\text { Head Loss (cm) } \\
\text { Elow Rate (mL/sec) } \\
\text { Eate in Draint flow } \\
\text { Filter (GPM) }\end{array}$ & $\begin{array}{c}\text { Column } \\
\text { with } \\
\text { Column } \\
\text { Glass } \\
\text { Alone }\end{array}$ & $\begin{array}{c}\text { Column, } \\
\text { Glass Wool, } \\
\text { Wool 1 cm of } \\
\text { Beads }\end{array}$ & $\begin{array}{c}\text { Beads } \\
\text { Alone }\end{array}$ \\
\hline 0.28 & 18 & 0.4 & 9.4 & 21.3 & 11.9 \\
\hline 0.56 & 36 & 0.5 & 16.7 & 40.5 & 23.8 \\
\hline 0.84 & 54 & 0.6 & 23.1 & 56.0 & 32.9 \\
\hline 1.12 & 72 & 0.8 & 28.9 & 69.9 & 41.0 \\
\hline 1.4 & 90 & 1.1 & 37.3 & 85.0 & 47.7 \\
\hline
\end{tabular}




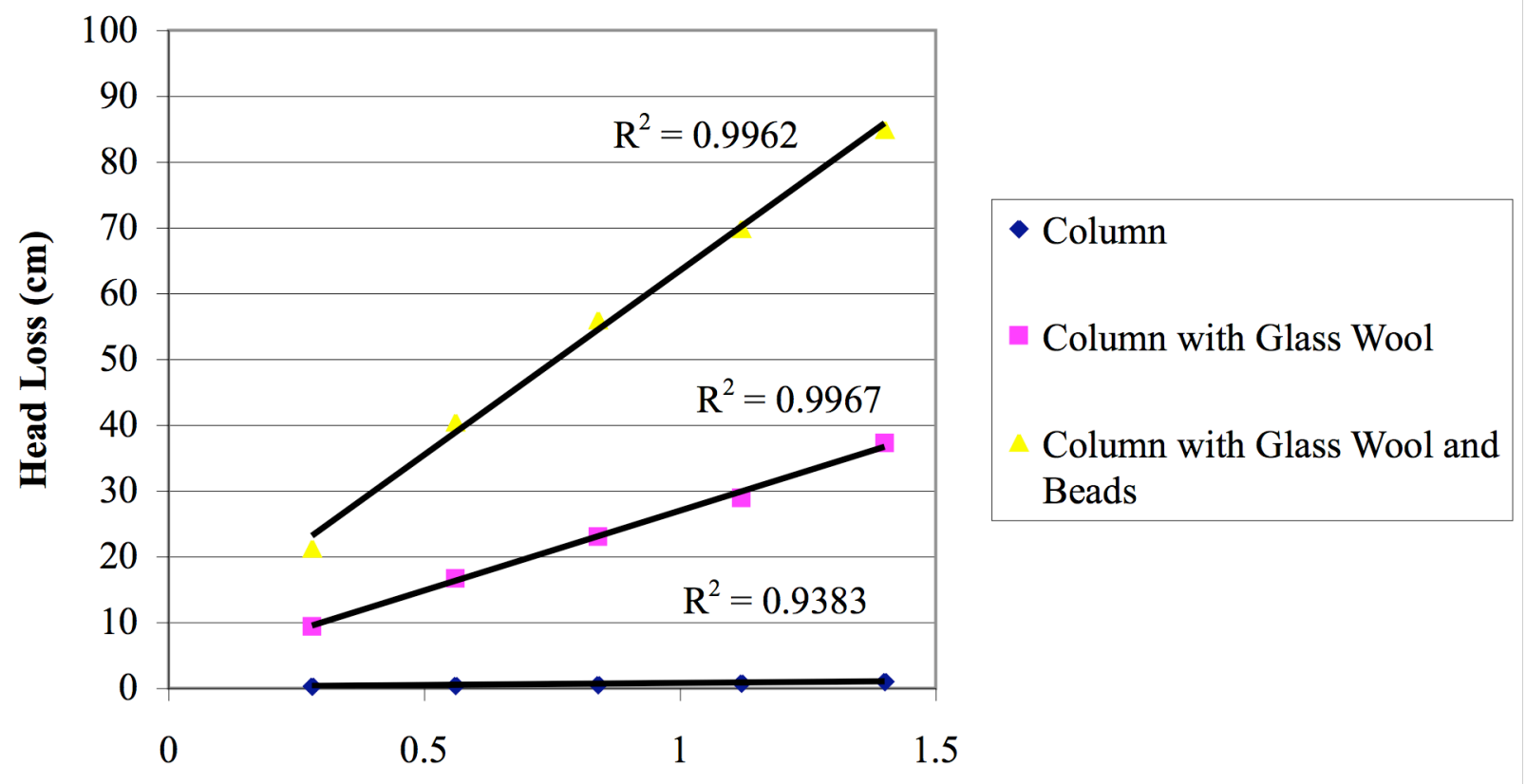

Flow Rate (ml/sec)

Figure 23. Head losses through the laboratory column and $0.8 \mathrm{~mm}$ N-halamine beads

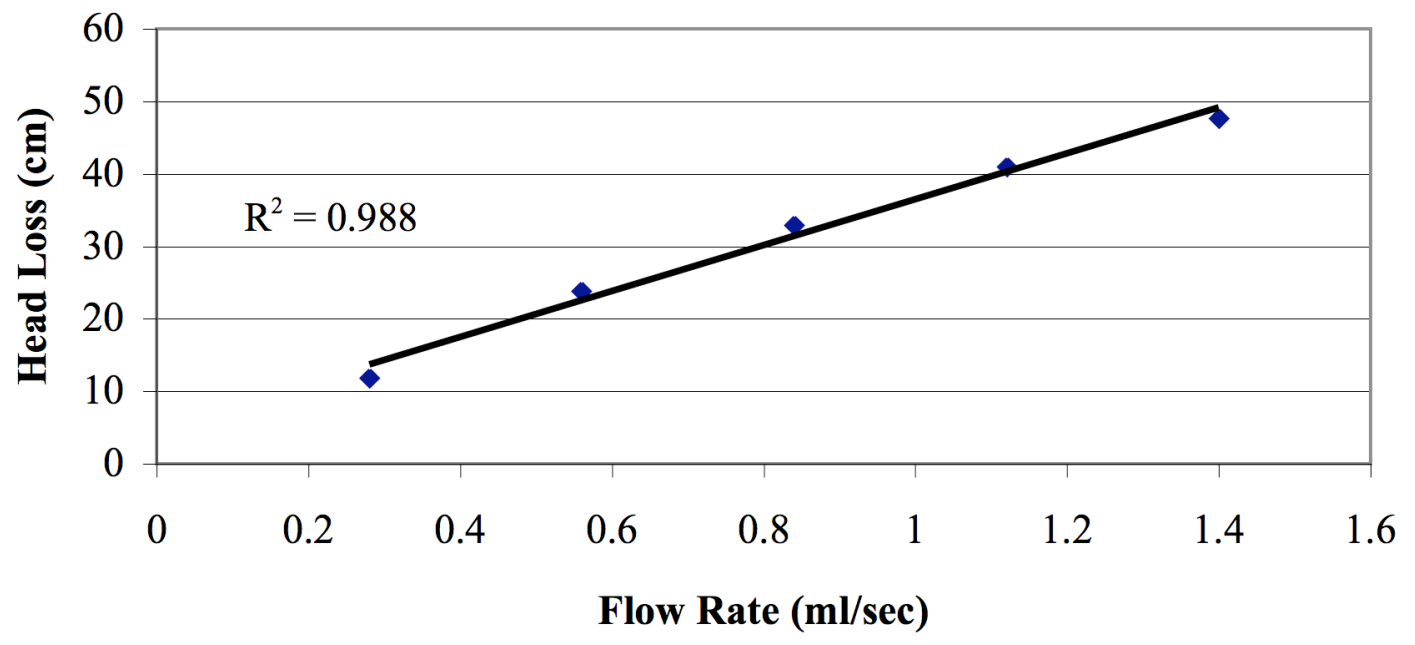

Figure 24. Head loss through $0.8 \mathrm{~mm}$ beads alone 


\subsubsection{Results of Control Test with Beads not Activated with Bromine}

The control test was conducted in the laboratory using beads without bromine activation. This control was necessary to account for any reduction in coliform counts that could be caused by bacteria being trapped in the glass wool packing or even sticking to the beads themselves. In order to accurately characterize the performance of the biocidal polymer bonded to the beads, it was necessary to control for these effects.

The results of the control test were rather showed significant bacteria removal without bromine activation. For the $0.3 \mathrm{~mm}$ beads, approximately $70 \%$ of the bacteria that entered the column were either trapped by the glass wool or stuck to the beads (Table 13). The column packed with un-charged $0.8 \mathrm{~mm}$ beads removed about $60 \%$ of the entering bacteria (Table 14).

Table 13. Results of control test with $0.3 \mathrm{~mm}$ beads in laboratory column at a flow rate of $0.56 \mathrm{~mL} / \mathrm{sec}$

\begin{tabular}{|l|c|c|c|}
\hline \multicolumn{1}{|c|}{ Quenching Method } & $\begin{array}{c}\text { Influent Average } \\
\text { (MPN/100 mL) }\end{array}$ & $\begin{array}{c}\text { Effluent } \\
\text { Average }\end{array}$ & $\begin{array}{c}\text { Removal Efficiency } \\
\text { (\%) }\end{array}$ \\
\hline Immediate quench & 2134 & 612 & 71.3 \\
\hline Quench after collection & 2134 & 476 & 77.7 \\
\hline Quench after 10 min & 2134 & 364 & 83.0 \\
\hline
\end{tabular}


Table 14. Results of control test with $0.8 \mathrm{~mm}$ beads in laboratory column at a flow rate of $0.56 \mathrm{~mL} / \mathrm{sec}$

\begin{tabular}{|c|c|c|c|}
\hline Quenching Method & $\begin{array}{c}\text { Influent Average } \\
\text { (MPN/100 mL) }\end{array}$ & $\begin{array}{c}\text { Effluent } \\
\text { Average }\end{array}$ & $\begin{array}{c}\text { Removal Efficiency } \\
\text { (\%) }\end{array}$ \\
\hline Immediate quench & 2161 & 825 & 61.8 \\
\hline Quench after collection & 2161 & 744 & 65.6 \\
\hline Quench after 10 min & 2161 & 674 & 68.8 \\
\hline
\end{tabular}

\subsubsection{Coliform Bacteria Removal Efficiency with Pond Water using $0.3 \mathrm{~mm}$ N- halamine beads (lab -scale)}

Samples which were quenched immediately showed bacteria inactivation efficiencies between $71.6 \%$ and $93.8 \%$, for flow rates from 0.28 to $0.84 \mathrm{~mL} / \mathrm{sec}$ (Table 15 ). For these samples which were quenched immediately, the bacteria inactivation efficiency decreased with increasing flow rate (Table 15). For samples which were quenched after sample collection, $99.6 \%$ and $99.9 \%$ percent of bacteria were inactivated at flow rates of 0.56 $\mathrm{mL} / \mathrm{sec}$ and $0.84 \mathrm{~mL} / \mathrm{sec}$, respectively. Given 10 minutes of contact time, all of the bacteria were inactivated regardless of the flow rate (Table 15).

For immediately quenched samples, the coliform removal efficiencies at $0.56 \mathrm{~mL} / \mathrm{sec}$ and $0.84 \mathrm{~mL} / \mathrm{sec}$ were very similar to the results of the control test conducted with beads which did not release bromine (Table 13 and Table 15). The bacteria were apparently not inactivated until experiencing some contact time after passing through the packed column. 
Table 15. Results of bacteria inactivation testing of $0.3 \mathrm{~mm}$ beads in a laboratory

column

\begin{tabular}{|c|l|c|c|c|}
\hline $\begin{array}{c}\text { Flow Rate in } \\
\text { Laboratory } \\
\text { Column } \\
(\mathbf{m L} / \mathbf{s e c})\end{array}$ & Quenching Method & $\begin{array}{c}\text { Influent } \\
\text { Average } \\
\mathbf{( M P N / 1 0 0 ~} \mathbf{~ m L )}\end{array}$ & $\begin{array}{c}\text { Total } \\
\text { Effluent Average } \\
\text { (MPN/100 mL) }\end{array}$ & $\begin{array}{c}\text { Coliform } \\
\text { Removal } \\
\text { Efficiency } \\
\mathbf{( \% )}\end{array}$ \\
\hline \multirow{4}{*}{0.28} & Immediate & 3417 & 213 & 93.8 \\
\cline { 2 - 5 } & After Sample Collection & - & - & - \\
\cline { 2 - 5 } & After 10 Minutes & 3417 & 0 & 100.0 \\
\hline \multirow{3}{*}{0.56} & Immediate & 4269 & 794 & 81.4 \\
\cline { 2 - 5 } & After Sample Collection & 4269 & 19 & 99.6 \\
\cline { 2 - 5 } & After 10 Minutes & 4269 & 0 & 100.0 \\
\hline \multirow{3}{*}{0.84} & Immediate & 3205 & 911 & 71.6 \\
\cline { 2 - 5 } & After Sample Collection & 3205 & 3 & 99.9 \\
\cline { 2 - 5 } & After 10 Minutes & 3205 & 0 & 100.0 \\
\hline
\end{tabular}

In the partner study conducted by fellow Cal Poly graduate student Ryan MacLure, the $\mathrm{N}$-halamine beads were found to release appreciable concentrations of bromine when water was passed through a packed column containing bromine activated beads (Table 16). 
Table 16. Effluent bromine concentrations from the laboratory column with $0.3 \mathrm{~mm}$ and $0.8 \mathrm{~mm}$ biocidal beads at $0.56 \mathrm{~mL} / \mathrm{sec}$ (MacLure, 2009)

\begin{tabular}{|c|c|c|}
\hline $\begin{array}{l}\text { Testing } \\
\text { Scenario }\end{array}$ & Sample & $\begin{array}{l}\text { Bromine Concentration } \\
\qquad(\mathrm{mg} / \mathrm{L})\end{array}$ \\
\hline \multirow{5}{*}{$\begin{array}{l}0.3 \mathrm{~mm} \\
\text { beads }\end{array}$} & DI Flush Water & 0.9 \\
\hline & Pond 1 & 0.5 \\
\hline & Pond 2 & 0.5 \\
\hline & Pond 3 & 0.4 \\
\hline & Pond average & 0.47 \\
\hline \multirow{5}{*}{$\begin{array}{c}0.8 \mathrm{~mm} \\
\text { beads }\end{array}$} & DI Flush Water & 0.5 \\
\hline & Pond 1 & 0.3 \\
\hline & Pond 2 & 0.3 \\
\hline & Pond 3 & 0.2 \\
\hline & Pond average & 0.27 \\
\hline \multirow{4}{*}{$\begin{array}{c}0.8 \mathrm{~mm} \\
\text { Inactivated } \\
\text { beads }\end{array}$} & DI Flush Water & 0 \\
\hline & Pond 1 & 0 \\
\hline & Pond 2 & 0 \\
\hline & Pond 3 & 0 \\
\hline
\end{tabular}


The bacteria removal efficiencies observed in this study appear to be directly related to contact time between bacteria and water containing residual bromine released from the N-halamine beads. As the contact time increases, the bacteria inactivation efficiency increases dramatically.

These results show that the main mechanism by which the N-halamine biocidal beads inactivate bacteria is by releasing small levels of bromine into the water, and relying on sufficient contact time with water containing bromine at approximately $0.5 \mathrm{mg} / \mathrm{L}$ to inactivate the bacteria (Table 16). This is very similar to what could be accomplished with chlorine or bromine tablets which slowly release chlorine or bromine.

\subsubsection{Coliform Bacteria Removal Efficiency with Pond Water using $0.8 \mathrm{~mm}$ N- halamine beads (lab-scale)}

The $0.8 \mathrm{~mm}$ diameter N-halamine beads inactivated between $61.1 \%$ and $78.4 \%$ of bacteria at flow rates between $0.28 \mathrm{~mL} / \mathrm{sec}$ and $0.84 \mathrm{~mL} / \mathrm{sec}$. When the samples were quenched after collection, between $96.2 \%$ and $99.4 \%$ of bacteria were inactivated. When the samples were allowed to sit for 10 minutes before quenching, $100 \%$ of the bacteria were inactivated regardless of flow rate (Table 17). As with the $0.3 \mathrm{~mm}$ beads, the bacteria inactivation efficiencies observed for samples passed through $0.8 \mathrm{~mm}$ beads and quenched immediately are comparable to the results observed with inactive (control) beads. 
Table 17. Results of bacteria inactivation testing of $0.8 \mathrm{~mm}$ beads in a laboratory

column.

\begin{tabular}{|c|l|c|c|c|}
\hline $\begin{array}{c}\text { Flow Rate in } \\
\text { Laboratory } \\
\text { Column } \\
(\mathbf{m L} / \mathbf{s e c})\end{array}$ & \multicolumn{1}{|c|}{ Quenching Method } & $\begin{array}{c}\text { Influent } \\
\text { Average } \\
\text { (MPN/100 } \\
\mathbf{m L})\end{array}$ & $\begin{array}{c}\text { Effluent } \\
\text { Average } \\
\text { (MPN/100 } \\
\mathbf{m L})\end{array}$ & $\begin{array}{c}\text { Total } \\
\text { Coliform } \\
\text { Removal } \\
\text { Efficiency } \\
\mathbf{( \% )}\end{array}$ \\
\hline \multirow{3}{*}{0.28} & Immediate & 744 & 173 & 76.7 \\
\cline { 2 - 5 } & After Sample Collection & 744 & 27 & 96.4 \\
\cline { 2 - 5 } & After 10 Minutes & 744 & 0 & 100.0 \\
\hline \multirow{3}{*}{0.56} & Immediate & 727 & 157 & 78.4 \\
\cline { 2 - 5 } & After Sample Collection & 727 & 28 & 96.2 \\
\cline { 2 - 5 } & After 10 Minutes & 727 & 0 & 100.0 \\
\hline \multirow{3}{*}{0.84} & Immediate & 270 & 105 & 61.1 \\
\cline { 2 - 5 } & After Sample Collection & 270 & 2 & 99.4 \\
\cline { 2 - 5 } & After 10 Minutes & 270 & 0 & 100.0 \\
\hline
\end{tabular}

The results for the $0.8 \mathrm{~mm}$ beads are very similar to the results for the $0.3 \mathrm{~mm}$ diameter beads. The inactivation efficiencies for samples passed through $0.8 \mathrm{~mm}$ beads and quenched immediately are slightly lower than those observed for $0.3 \mathrm{~mm}$ beads. This can be explained by the lower observed bromine concentration (approximately $0.3 \mathrm{mg} / \mathrm{L}$ compared to $0.5 \mathrm{mg} / \mathrm{L}$ : See MacLure, 2009) released from the $0.8 \mathrm{~mm}$ beads as well as the lower bacteria inactivation efficiency observed with the $0.8 \mathrm{~mm}$ inactive (control) beads (Table 14 and Table 17).

Clearly both sizes of bead are able to leach sufficient bromine to inactivate bacteria if given even a short contact time (Table 15 and Table 17). This further supports that contact time with residual bromine at is the mechanism for bacteria inactivation. 


\subsubsection{Bacterial Removal Efficiency using $0.3 \mathrm{~mm}$ N-halamine Beads with $E$. coli strain K-12}

The $0.3 \mathrm{~mm}$ N-halamine beads inactivated $52.4 \%$ of the influent $E$. coli bacteria when the sample was quenched immediately. When the sample was quenched after collection, the observed bacteria inactivation efficiency was $96.8 \%$. When the sample was quenched after 10 minutes, $100 \%$ of the bacteria was inactivated. These results are summarized in Table 18.

The tests conducted with $E$. coli strain K-12 utilized concentrations that were approximately 5 orders of magnitude higher than the tests using pond water. Despite this challenge, the N-halamine beads produced similar removal efficiencies to those observed for lower bacteria concentrations in pond water. The beads were still able to inactivate 100 percent of the influent bacteria with a contact time of 10 minutes. This shows that the performance of the beads is relatively uneffected by the influent concentration of bacteria.

Table 18. Bacteria inactivation efficiency of $0.3 \mathrm{~mm}$ beads and high concentrations of $E$. coli at $0.56 \mathrm{~mL} / \mathrm{sec}$

\begin{tabular}{|c|c|c|c|}
\hline Quenching Method & $\begin{array}{c}\text { Influent Average } \\
\text { (MPN/100 mL) }\end{array}$ & $\begin{array}{c}\text { Effluent Average } \\
\text { (MPN/100 mL) }\end{array}$ & $\begin{array}{c}\text { Removal } \\
\text { Efficiency (\%) }\end{array}$ \\
\hline Immediate quench & $186,000,000$ & $88,700,000$ & 52.4 \\
\hline Quench after collection & $186,000,000$ & $5,980,000$ & 96.8 \\
\hline Quench after 10 min & $186,000,000$ & 0 & 100.0 \\
\hline
\end{tabular}


The results for the 10 minute quench are comparable to those observed by Chen et al. in 2003. In that study, water containing $6.9 \times 10^{6} \mathrm{CFU} / 100 \mathrm{~mL}$ was passed through a packed column in a similar manner, and all of the bacteria were observed to be inactivated. The time elapsed before quenching is not disclosed in the study by Chen et al., so it is not known if such results would have been observed with instant quenching.

\subsubsection{Bead longevity tests with $0.3 \mathrm{~mm}$ N-halamine beads (lab-scale)}

After 5 cycles of use ( $1 \mathrm{hr}$ filtering/23 hrs drying), the N-halamine beads were no longer releasing sufficient bromine to effectively inactivate bacteria, as shown in Table 19 below. Bacteria inactivation after 5 cycles was lower than that observed for the control test using inactive beads (Table 13 and Table 19). This could be due to the beads becoming less tightly packed after repeated use. It could also be dependent on the mass loading of bacteria (mass loading was lower in longevity tests due to the pre-filter). In the companion study conducted by Ryan MacLure, the bromine concentration leaching from the $0.3 \mathrm{~mm}$ beads after 5 cycles of use decreased to $0.37 \mathrm{mg} / \mathrm{L}$, a drop of approximately 20\% (MacLure, 2009).

In a full scale stormwater application, the beads would be subject to buildup of biological matter and sediment, unlike in this experiment where a pre-filter was used. 
Table 19. Results of bead longevity test with $0.3 \mathrm{~mm}$ beads after five $1-\mathrm{hr}$ flow cycles

at $0.56 \mathrm{~mL} / \mathrm{sec}$

\begin{tabular}{|c|c|c|c|}
\hline Quenching Method & $\begin{array}{c}\text { Influent Average } \\
\text { (MPN/100 mL) }\end{array}$ & $\begin{array}{c}\text { Effluent Average } \\
\text { (MPN/100 mL) }\end{array}$ & $\begin{array}{c}\text { Removal } \\
\text { Efficiency (\%) }\end{array}$ \\
\hline Immediate quench & 428 & 224 & 47.8 \\
\hline Quench after collection & 428 & 167 & 61.1 \\
\hline Quench after 10 min & 428 & 136 & 68.3 \\
\hline
\end{tabular}

The beads which were wetted and then allowed to sit in ambient conditions for over 5 months inactivated between 57.3 and 88.6 percent of influent bacteria (Table 20). This is comparable to the results observed for the control (inactive) beads (Table 13). This result does not match with observed results of longevity testing reported by Ryan MacLure in the companion study. In the companion study, the beads were found to release the same concentration of bromine after extended dry storage (MacLure, 2009).

Table 20. Results of bead longevity test at $0.56 \mathrm{~mL} / \mathrm{sec}$ with $0.3 \mathrm{~mm}$ beads allowed to sit dry for over 5 months

\begin{tabular}{|c|c|c|c|}
\hline Quenching Method & $\begin{array}{c}\text { Influent Average } \\
\text { (MPN/100 mI) }\end{array}$ & $\begin{array}{c}\text { Effluent Average } \\
\text { (MPN/100 ml) }\end{array}$ & $\begin{array}{c}\text { Removal } \\
\text { Efficiency (\%) }\end{array}$ \\
\hline Immediate quench & 738 & 315 & 57.3 \\
\hline Quench after collection & 738 & 322 & 56.3 \\
\hline Quench after 10 min & 738 & 84.4 & 88.6 \\
\hline
\end{tabular}




\subsection{Full-Scale Testing of N-halamine Beads in the DrainPac ${ }^{\mathrm{TM}}$ filter}

The sleeve of N-halamine beads integrated well with the DrainPac ${ }^{\mathrm{TM}}$ filter. The

DrainPac $^{\mathrm{TM}}$ filter with sleeves of N-halamine beads did not cause excessive head loss as was observed in the lab-scale testing. At 36 gpm, very little standing water was observed above the beads, indicating that the system could potentially work at higher flow rates.

Coliform removal efficiency ranged from $72.5 \%$ up to $100 \%$ depending on the amount of contact time between the bacteria and the bromine which had leached from the beads (Table 21).

Table 21. Results of full scale testing of N-halamine beads

\begin{tabular}{|c|c|c|}
\hline Sample ID & $\begin{array}{c}\text { Quenching } \\
\text { Time }\end{array}$ & $\begin{array}{c}\text { Inactivation Efficiency } \\
(\%)\end{array}$ \\
\hline Q-0 & $30 \mathrm{sec}$ & 72.5 \\
\hline Q-1 & $2 \mathrm{~min}$ & 89.5 \\
\hline Q-2 & $3 \mathrm{~min}$ & 97.9 \\
\hline Q-10 & $10 \mathrm{~min}$ & 100.0 \\
\hline
\end{tabular}

These results are very comparable to those observed with beads packed in laboratory columns, which were also able to inactivate $100 \%$ of the influent bacteria after a contact time of 10 minutes (Table 17). Research conducted by Dr. Yarrow Nelson and Dr. Ben Burgoa in conjunction to this full-scale study indicated that the beads were releasing concentrations of bromine between 0.6 and $0.8 \mathrm{mg} / \mathrm{L}$ (Nelson et al. 2009). This is slightly higher than the concentrations measured by Ryan MacLure using laboratory columns. 


\section{CHAPTER 5: CONCLUSIONS}

\subsection{Experimental Conclusions}

This section discusses the conclusions which were reached about the performance of the DrainPac $^{\mathrm{TM}}$ filter and the N-halamine brominated biocidal beads.

\subsubsection{DrainPac ${ }^{\mathrm{TM}}$ Filter Conclusions without N-halamine beads}

The DrainPac ${ }^{\mathrm{TM}}$ filter creates minimal head loss when not loaded with solids. A clean unit can handle flow rates of over 200 GPM and maintain a water level in the filter of slightly over half of the height of the filter cloth. As the filter is loaded with solids, the head loss rises rapidly. The highest flow rate possible with a filter loaded with $625 \mathrm{~g}$ of solids was 80 GPM. This could be an issue in areas with high rainfall and/or high solids loadings, as the filter could potentially fill up with solids to the point of failure in a short amount of time. Proper planning and maintenance routines could possibly mitigate this issue.

The filter proved to be effective at removing between $83 \%$ and $91 \%$ of suspended sediment from simulated stormwater, depending on the influent flow rate. This is consistent with the results reported by Stenstrom (1998) who reported just slightly greater removal efficiencies. The variation between the results of the current study and that of Stenstrom are likely due to differences in characteristics of the solids used for testing. The study conducted by Stenstrom used solids removed from catch basins, and included large items such as leaves, cigarette butts, and pebbles. The solids used in the current study were composed of fine sediments (including algae and bacteria) from the pond 
water, supplemented with fine sand. The removal efficiency would be expected to be higher for large particles which are easier to remove and cause less clogging.

The oil removal efficiency of the filter varied from $40 \%$ to $82 \%$. The oil removal efficiency did not appear to be dependent on the flow rate. There are several possible explanations for the lack of a trend in oil removal efficiencies. Because the oil is hydrophobic, it forms into small droplets as it travels across the surface of the flume before entering the filter. This means that the inflow is not a homogenous mixture, and variability will occur. In addition, the results were likely affected by the amount of sediment which was collected in the filter prior to the addition of oil. The oil may stick to these solids, creating variability in the effluent quality. Despite the variable results, the range in oil removal efficiencies in the present study are very similar to the $49 \%$ to $86 \%$ removal efficiencies found by Stenstrom in 1998. Because of the variable results, careful consideration should be given before installing the DrainPac ${ }^{\mathrm{TM}}$ filter in applications which require reliable high oil removal efficiencies.

The DrainPac ${ }^{\mathrm{TM}}$ filter without added N-halamine beads did not remove/inactivate coliform bacteria. It is likely that the bacteria (or small flocs of bacteria) are just too small to be physically removed by the cloth material of the DrainPac ${ }^{\mathrm{TM}}$ filter. 


\subsubsection{N-halamine Biocidal Brominated Bead Conclusions (Laboratory Column)}

The N-halamine beads do not instantly inactivate bacteria as it passes by the beads in a stream of water. When the samples were quenched immediately, the bacteria removal efficiency was no better than in control experiments. Instead, the beads rely on contact time with the released bromine to inactivate bacteria. This is similar to the mechanism used in pool chlorination systems. The results of this study are comparable to those reported by Chen et al. in 2003. In both cases, the N-halamine beads were able to inactivate all of the bacteria passed through a packed column as long as a small period elapsed before the residual bromine was quenched by the addition of sodium thiosulfate. The study by Chen et al. does not disclose the time elapsed before quenching.

Despite not inactivating bacteria instantly, the N-halamine beads are quite effective at inactivating bacteria when given even a short contact time. The samples which were quenched after collection were most representative of a real life application, where the

stormwater would remain in the catchment basin for a short period of time before flowing into the storm sewer system and getting diluted. Samples which were quenched after collection (approximately 95 to 285 seconds depending on flow rate) showed removal efficiencies of over $95 \%$. The influent bacteria concentration did not appear to have an effect on the removal efficiency. The beads performed equally well against bacteria concentrations differing by 5 orders of magnitude. 


\subsubsection{Longevity of $\mathrm{N}$-halamine Beads in Laboratory Column Experiments}

The N-halamine beads did not maintain their bacteria inactivating properties when either exposed to repeated cycles of use or after dry storage for 5 months after being wetted. This was surprising because the results observed by Ryan MacLure suggest that the Nhalamine beads were releasing approximately the same amount of bromine under the same conditions. Further research could potentially explain this discrepancy. The implications of this poor longevity are very important when considering possible stormwater treatment applications. If the N-halamine beads need frequent maintenance, the costs may become very high.

\subsubsection{Full Scale DrainPac ${ }^{\mathrm{TM}}$ filter with N-halamine Bead conclusions}

The N-halamine beads integrated well with the DrainPac ${ }^{\mathrm{TM}}$ filter. While the filter alone does not remove bacteria, the filter with N-halamine beads integrated into it removes up to $100 \%$ of the influent bacteria when given sufficient contact time. The contact time required for bacteria inactivation would likely be acheived in a full scale setting, as the water would remain in the catchment basin for a short period of time before flowing into a storm sewer system and getting diluted.

While the beads do seem to lack longevity, they still may be feasable for use in stormwater applications. If there are known "hot spots" for bacterial contamination, DrainPac $^{\mathrm{TM}}$ filters with integrated N-halamine beads could be strategically placed to intercept the flows. By using the units sparingly and strategically, the maintenance costs of swapping and recharging the beads could be minimized. 
From a hydraulic perspective, the DrainPac ${ }^{\mathrm{TM}}$ filter performed well with two sleeves of N-halamine beads layered into it. Minimal head loss was measured, and the customized DrainPac $^{\mathrm{TM}}$ filter did a good job of directing the flow through the N-halamine beads.

\subsubsection{Bromine leaching from $\mathrm{N}$-halamine beads}

In research conducted by fellow grad student Ryan MacLure in 2009, the effluent from a laboratory column setup using $0.3 \mathrm{~mm}$ beads contained $0.47 \mathrm{mg} / \mathrm{L}$ bromine, $2.45 \mathrm{mg} / \mathrm{L}$ bromoform, and $0.53 \mathrm{mg} / \mathrm{L}$ bromide. The effluent from a column packed with $0.8 \mathrm{~mm}$ beads contained $0.27 \mathrm{mg} / \mathrm{L}$ bromine, $0.06 \mathrm{mg} / \mathrm{L}$ bromoform, and $0.50 \mathrm{mg} / \mathrm{L}$ bromide. The lower leachate concentrations observed from the $0.8 \mathrm{~mm}$ beads can be attributed to the lower total surface area as well as a reportedly different manufacturing process (MacLure, 2009). The bromine, bromide, and bromoform leaching from the N-halamine beads could potentially pose problems in a full scale stormwater treatment application. This would depend on the regulatory limits for discharges to the particular watershed.

\subsection{Future Research}

This section suggests future research which would be helpful regarding N-halamine beads, DrainPac ${ }^{\mathrm{TM}}$ filters, and the integration of the two.

\subsubsection{DrainPac ${ }^{\mathrm{TM}}$ Filter Future Research}

In this study, tests were only conducted using one contaminant at a time. In a real situation, the DrainPac ${ }^{\mathrm{TM}}$ filter would need to be able to handle influent streams laden 
with sediment, debris, oil, and bacteria. Future tests could be conducted to determine how the removal efficiencies are effected by the presence of other contaminants. It is possible that the oil removal efficiency may increase as the layer of collected solids increases, creating a schmutzdecker layer.

Another test which would be useful would be to determine how the performance of the DrainPac $^{\mathrm{TM}}$ filter is effected when it is allowed to dry after being loaded with solids, debris, and organic matter. It is possible that the scummy layers observed on the filter material after a test run may dry into a crust, inhibiting flow through the cloth.

\subsubsection{N-halamine Brominated Biocidal Bead Future Research}

In this study, the longevity of the beads was first tested after 5 cycles of use (simulating storm events). Because the beads had lost their ability to inactivate bacteria after 5 cycles of use and measurements were not made after fewer cycles, the actual longevity of the beads remains unknown. This would be very useful information when considering the feasibility of using the beads in a full scale application.

Future experiments should be conducted to determine bacteria inactivation efficiency as a function of bromine concentration and contact time. These results could be compared to existing published disinfection models.

Also, additional research should be conducted to find possible ways to increase the longevity of the N-halamine beads. 


\subsubsection{Full-Scale Testing of N-halamine Beads in DrainPac ${ }^{\mathrm{TM}}$ Filter Future Research}

The full range of tests conducted on the DrainPac ${ }^{\mathrm{TM}}$ filter could be repeated using a DrainPac $^{\mathrm{TM}}$ filter with integrated N-halamine beads. When the sleeves of beads are added to the filter, it also adds 4 additional layers of the same filter material that the DrainPac ${ }^{\mathrm{TM}}$ filter employs.

Additional research needs to be conducted regarding the concentrations of bromine, bromide, and bromoform which are leached from the N-halamine beads in a full scale application prior to any implementation. These chemicals are regulated in discharges to receiving waters.

Tests should be conducted comparing the use of sleeves containing N-halamine beads to the use of chlorine or bromine tablets. If tablets were added in a way which achieves the same effluent bromine concentration, valid comparisons could be made.

The sleeves of N-halamine beads used in this study should be tested again after given amounts of time to determine their longevity in a full scale application. 


\section{REFERENCES}

Ahn, J. H., Grant, S. B., Surbeck, C. Q., DiGiacomo, P. M., Nezlin, N. P., Jiang, S. (2005). "Coastal Water Quality Impact of Stormwater Runoff from an Urban Watershed in Southern California.” Environ. Sci. Technol., 2005, 39 (16), pp 5940-5953

American Public Health Association. (1999a). Standard methods for the examination of water and wastewater (Partition-Gravimetric Method, 5520 B.), 20th Edition. American Public Health Association, Washington, DC.

American Public Health Association. (1999b). Standard methods for the examination of water and wastewater (Total Suspended Solids Dried at $103-105^{\circ} \mathrm{C}$, Method \#2540 D), 20th Edition. American Public Health Association, Washington, DC.

Barnhart, R. A. (1986). "Species Profiles: Life Histories and Environmental Requirements of Coastal Fishes and Invertebrates (Pacific Southwest). STEELHEAD." California Cooperative Fishery Research Unit, Humboldt State University, Arcata, CA. June 1986.

Booth, D. B. and Jackson, C. R., (1997). "Urbanization of aquatic systems: degradation of thresholds, stormwater detection, and the limits of mitigation." Journal of the American Water Resources Association 33: 5 pp. 1077-1090.

Chen, Y., Worley, S. D., Kim, J., Wei, C.-I., Chen, T.-Y. (2003). “Biocidal Poly(styrenehydantoin) Beads for Disinfection of Water." Ind. Eng. Chem. Res. 2003, 42, 280-284.

Chen, Y., Worley, S. D., Huang, T. S., Weese, J., Kim, J., Wei, C.-I., and Williams, J.F. (2004a). "Biocidal Polystyrene Beads. III. Comparison of N-halamine and Quat Functional Groups.” Journal of Applied Polymer Science 92, pp. 363-367.

Chen, Y., Worley, S. D., Huang, T. S., Weese, J., Kim, J., Wei, C.-I., and Williams, J. F. (2004b). "Biocidal Polystyrene Beads. IV. Functionalized Methylated Polystryene." Journal of Applied Polymer Science 42, pp. 368-372.

Chiras, Daniel, D. Environmental Science, Seventh Edition. Sudbury, MA: Jones \& Bartlett, 2006.

Dietz, M. E., Clausen, J. C. (2005). "Saturation to Improve Pollutant Retention in a Rain Garden.” Environ. Sci. Technol., 2005, 39 (16), pp 5940-5953.

Diniz, E. V. (1980). "Porous Pavement: Phase I - Design and Operational Criteria." Office of Research and Development - U.S. Environmental Protection Agency Cincinnati, Ohio. August 1980. 
Engelhaupt, E. (2008). "Parking lots create sticky pollution problem." Environ. Sci. Technol., 2009, 43 (1), p 3

Geldreich, E. E., Best, L.C., Kenner, B. A., and Van Donsel, D. J. (1968) "The bacteriological aspects of stormwater pollution." Journal (Water Pollution Control Federation), Vol. 40, No. 11, Part I (Nov., 1968), pp. 1861-1872

Hatt, B. E., Fletcher, T. D., Deletic, A. (2008). "Hydraulic and Pollutant Removal Performance of Fine Media Stormwater Filtration Systems." Environ. Sci. Technol., 2008, 42 (7), pp 2535-2541.

Hipp, A. J., Ogunseitan, O., Lejano, R., Smith, C. S. (2006). "Optimization of Stormwater Filtration at the Urban/Watershed Interface.” Environ. Sci. Technol., 2006, 40 (15), pp 4794-4801

Lubick, N. (2006). "Using nature's design to stem urban storm-water problem." Environ. Sci. Technol., 2005, 39 (16), pp 5940-5953.

MacLure, R. (2009). Performance of a Catch Basin Filter and Leachate from Biocidal Media for Stormwater Treatment. Masters Thesis, California Polytechnic State University, San Luis Obispo.

Metcalf and Eddy, Tchobanoglous, G., Burton, F.L., and Stensel, H.D. (2003).

Wastewater Engineering: Treatment and Reuse. 4th Eddition. McGraw HIl ISBN-13: 978-0-07-041878-3.

Morgan, R. A., Edwards, F. G., Brye, K. R., and Burian, S. J. (2005). "An Evaluation of the Urban Stormwater Pollutant Removal Efficiency of Catch Basin Inserts." Water Environment Research 77: 5, pp. 500-510.

Murakami, M., Sato, N., Anegawa, A., Nakada, N., Harada, A., Komatsu, T., Takada, H., Tanaka, H., Ono, Y., and Furumai, H. (2008). "Multiple Evaluations of the Removal of Pollutants in Road Runoff by Soil Infiltration." Water Research 42: 10-11, pp. 27452755.

Parker, T. C., Fossum, K. D., Ingersoll, T. L. (2000). "Chemical Characteristics of Urban Stormwater Sediments and Implications for Environmental Management, Maricopa County, Arizona." Environ Manage. 2000 Jul;26(1):99-115.

San Luis Obispo County (2010). Beach Health Advisories. Retreived March 10, 2010 from San Luis Obispo County website:

http://www.slocounty.ca.gov/health/publichealth/ehs/beach.htm 
Siriwardene, N. R., Deletic, A., Fletcher, T. D. (2007). "Modeling of Sediment Transport through Gravel Filters over Their Lifrespan.” Environ. Sci. Technol., 2007, 41 (23), pp 8099-8103.

Sonstrom, R. S., Clausen, J. C. , Askew, D. R. (2002). "Treatment of Parking Lot Stormwater Using a StormTreat System." Department of Natural Resources Management and Engineering, University of Connecticut. Environ. Sci. Technol., 2002, 36 (20), pp $4441-4446$

Stenstrom, M. (1998). UCLA DrainPac test report--- UCLA 1998. letter from Dr. Michael Stenstrom, UCLA Prof Civil Eng. to Mr. Paul Corn of United Pumping Services (manufacturer of Drain Pac Filters) detailing results of lab tests performed on Drain Pac Filters. September 25, 1998 $\geq$

Sun, G., Chen, T. Y., Habercom, M. S., Wheatley, W. B., and Worley, S. D. (1996). "Performance of a New Polymeric Water Disinfectant." Water Resources Bulletin 32: 4, pp. 793-797.

Surbeck, C. Q., Jiang, S. C., Ahn, J. H., Grant, S. B. (2006). "Flow Fingerpringting Fecal Pollution and Suspewnded Solids in Stormwater Runoff from an Urban Coastal Watershed." Environ. Sci. Technol., 2005, 39 (16), pp 5940-5953.

U.S. Environmental Protection Agency (1986). Methodology for Analysis of Detention Basins for Control of Urban Runoff Quality. Retreived 10 March, 2010 from: http://www.epa.gov/ednnrmrl/publications/reports/epa440587001/titletocsection.pdf

U.S. Environmental Protection Agency (2007). The National Water Quality Inventory: Report to Congress for the 2002 Reporting. Retreived 10 March, 2010 from: http://www.epa.gov/305b

U.S. Environmental Protection Agency (2008a). Low Impact Development. Retrieved December 29, 2008 from EPA website: http:/www.epa.gov/nps/lid/

U.S. Environmental Protection Agency (2008b). National Pollutant Discharge System. Retrieved December 10, 2009 from EPA website:

http://cfpub.epa.gov/npdes/stormwater/swbasicinfo.cfm

U.S. Environmental Protection Agency (2008c). Used Oil Management Program.

Retrieved March 10, 2010 from EPA website:

http://www.epa.gov/epawaste/conserve/materials/usedoil

U.S. Environmental Protection Agency (2008d). National of Best Management Practices. Retrieved March 10, 2010 from EPA website:

http://cfpub.epa.gov/npdes/stormwater/menuofbmps/index.cfm 
U.S. Environmental Protection Agency (2009). The National Water Quality Inventory: Report to Congress for the 2004 Reporting. Retreived 10 March, 2010 from:

http://www.epa.gov/305b

Worley, S. D., Sun, G., Sun, W., and Chen, T. Y. (1996). Polymeric Cyclic N-Halamine Biocidal Compounds. U.S. Patent 5,490,983. 


\section{Appendix A. Colilert® method procedure}

\section{Colilert ${ }^{\circledast}$ Test Kit}

\section{Introduction}

Colilert simultaneously detects total colif orms and $E$. coli in water. It is based on IDEXX's patented Defined Substrate Technology ${ }^{\odot}$ $\left(\mathrm{DST}{ }^{\oplus}\right)$. When total coliforms metabolize Colilert's nutrient-indicator, ONPG, the sample turns yellow. When E. coli metabolize

Colilert's nutrient-indicator, MUG, the sample fluoresces. Colilert can simultaneously detect these bacteria at 1 cfu/ $100 \mathrm{~mL}$ within 24 hours even with as many as 2 million heterotrophic bacteria per $100 \mathrm{~mL}$ present.

\section{Contents}

WP020l contains 20 Snap Packs for $100 \mathrm{~mL}$ samples WP200l contains 200 Snap Packs for $100 \mathrm{~mL}$ samples W050l contains 20 Snap Packs for $50 \mathrm{~mL}$ samples W050B contains 200 Snap Packs for $50 \mathrm{~mL}$ samples

\section{Storage}

Store at $2^{\circ}-30^{\circ} \mathrm{C}$ away from light.

\section{Presence/Abs ence ( $\mathrm{P} / \mathrm{A})$ Procedure}

1. Add contents of one pack to a $100 \mathrm{~mL}$ sample (50 mL for W050l and W050Bl) in a sterile, transparent, nonfluorescing vessel.

2. Cap vessel and shake.

3. Incubate at $35^{\circ} \mathrm{C} \pm 0.5^{\circ} \mathrm{C}$ for 24 hours.

4. Read results according to Result Interpretation table below.

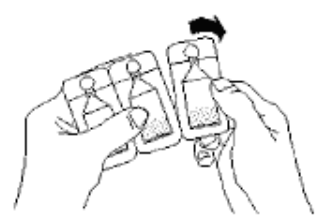

Quanti-Tray Enumeration Procedure (WP020l and WP200l only)

1. Add contents of one pack to a $100 \mathrm{~mL}$ water sample in a sterile vessel.

2. Cap vessel and shake until dissolved.

3. Pour sample/reagent mixture into a Quanti-Tray or Quanti-Tray $\odot / 2000$ and seal in an IDEXXQuanti-Tray ${ }^{\odot}$ Sealer.

4. Place the sealed tray in a $35^{\circ} \mathrm{C} \pm 0.5^{\circ} \mathrm{C}$ incubator for 24 hours.

5. Read results according to the Result Interpretation table below. Count the number of positive wells and refer to the MPN table provided with the trays to obtain a Most Probable Number.

\section{Result Interpretation}

Appearance
\begin{tabular}{|l|l|}
\hline Less yellow than the comparator & Negative for total coliforms and $E$. coli \\
\hline $\begin{array}{l}\text { Yellow equal to or greater than } \\
\text { the compa rator }\end{array}$ & Positive for total coliforms \\
\hline $\begin{array}{l}\text { Yellow and fluorescence equal to or } \\
\text { greater than the comparator }\end{array}$ & Positive for $E$. coil \\
\hline
\end{tabular}

- Look for fluorescence with a 6-watt, 365-nm UV light within 5 inches of the sample in a dark environment. Face light away framurair areno and taurardo tha osmala 


\section{Procedural Notes}

- This insert may not reflect your local regulations. For compliance testing, be sure to follow appropriate regulatory procedures.

- Colilert can be run in any multiple tube format. Standard Methods for the Examination of Water and Wastewater** MPN tables should be used to find Most Probable Numbers (MPNs).

- If a water sample has some background color, compare inoculated Colilert sample to a control blank of the same water sample.

- If sample dilutions are made, multiply the MPN value by the dilution factor to obtain the proper quantitative result.

- Use only sterile, nonbuffered, oxidant-free water for dilutions.

- Colilert is a primary water test. Colilert performance characteristics do not apply to samples altered by any pre-enrichment or concentration.

- In samples with excessive chlorine, a blue flash may be seen when adding Colilert. If this is seen, consider sample invalid and discontinue testing

- Aseptic technique should always be followed when using Colilert. Dispose of in accordance with Good Laboratory Practices.

\section{Quality Control Procedures}

The following quality control procedure is recommended for each lot of Colilert:

1. Inoculate 3 sterile vessels filled with $100 \mathrm{~mL}$ sterile water with the following:

A. one with Quanti-Cult ${ }^{\mathrm{m} * * *}$ E. coli or a sterile loop of ATCC**** 25922 or 11775 (E. colf)

B. one with Quanti-Cult Kebsiefla pneumoniae or a sterile loop of ATCC 31488 (total colif orm)

C. one with Quanti-Cult Pseudomonas aenginosa or a sterile loop of ATCC 10145 or 27853 (noncoliform)

2. Follow the P/A Procedure or Quanti-Tray Enumeration Procedure above.

* IDEXX P/A Comparator, catabg \#WP104; Quanti-Tray Comparator \#WOTC, or Quanti-Tray/2000 Comparator \#WOT 2KC

** Eaton AD, Cesceri LS, GreentergAE. Standard Mathod's for the Examination of Whater and Whastewater. Amencan Public Health Association, 1998, Washington, DC.

*th Quanti-Cultcultures - IDEXXGatalog \# WKIT-1001

*iththamerican Type Culture Collection 1-800-638-6597

Coliert, Defined Substrate Technology, DST and Quanti-tray are eitter trademarks or registered trademarks of IDEXX Laboratories, Inc. in the Unitted States andVor ottrer countries. Quanti-Cult is a trademark of Femel Inc.

(6) 2007 IDEXX Laboratories, Inc. All rights resened.

Manufactured under one or more of the following U.S. patents: $4,925,789 ; 5,429,933 ; 5,518,892 ; 5,610,029 ; 5,620,865 ; 5,600,895 ; 5,753,456$ and $5,780,259$. Other U.S. andior fnrpinn natents issipen ne nemim 


\section{Appendix B. Raw data from TSS removal testing}

\section{GPM}

\begin{tabular}{|l|l|l|l|l|}
\hline Water Type & Wt. Before $(\mathrm{g})$ & Wt. After $(\mathrm{g})$ & Volume $(\mathrm{mL})$ & TSS $(\mathrm{mg} / \mathrm{L})$ \\
\hline Pond 1 & 1.061 & 1.0614 & 250 & \\
\hline Pond 2 & 1.0911 & 1.0921 & 280 & 2.641509434 \\
\hline Influent 1 & 1.086 & 1.088 & 250 & \\
\hline Influent 1 & 1.0614 & 1.093 & 287 & 62.5698324 \\
\hline Influent 2 & 1.0531 & 1.0538 & 250 & \\
\hline Influent 2 & 1.051 & 1.0787 & 270 & 54.61538462 \\
\hline Influent 3 & 1.0522 & 1.0527 & 250 & \\
\hline Influent 3 & 1.0614 & 1.0951 & 290 & 63.33333333 \\
\hline Effluent 1 & 1.0651 & 1.0663 & 250 & \\
\hline Effluent 1 & 1.078 & 1.0799 & 291 & 5.73012939 \\
\hline Effluent 2 & 1.073 & 1.0738 & 250 & \\
\hline Effluent 2 & 1.071 & 1.0725 & 292 & 4.243542435 \\
\hline Effluent 3 & 1.0626 & 1.0635 & 250 & \\
\hline Effluent 3 & 1.0489 & 1.0515 & 285 & 6.542056075 \\
\hline
\end{tabular}

$60 \mathrm{GPM}$

\begin{tabular}{|c|c|c|c|c|}
\hline Water Type & Wt. Before (g) & Wt. After (g) & Volume (mL) & TSS (mg/L) \\
\hline Pond 1 & 1.0663 & 1.0351 & 250 & \multirow{2}{*}{-2047.83} \\
\hline Pond 2 & 1.0521 & & 279 & \\
\hline Influent 1 & 1.1336 & 1.1341 & 250 & \multirow{2}{*}{22.95} \\
\hline Influent 1 & 1.0768 & 1.0889 & 299 & \\
\hline Influent 2 & 1.0716 & 1.0718 & 250 & \multirow{2}{*}{37.59} \\
\hline Influent 2 & 1.0301 & 1.0505 & 298 & \\
\hline Influent 3 & 1.0943 & 1.0948 & 250 & \multirow{2}{*}{51.84} \\
\hline Influent 3 & 1.0883 & 1.116 & 294 & \\
\hline Effluent 1 & 1.0939 & 1.0949 & 250 & \multirow{2}{*}{4.73} \\
\hline Effluent 1 & 1.086 & 1.0875 & 278 & \\
\hline Effluent 2 & 1.0663 & 1.0667 & 250 & \multirow{2}{*}{1.30} \\
\hline Effluent 2 & 1.0778 & 1.0781 & 289 & \\
\hline Effluent 3 & 1.0721 & 1.0728 & 250 & \multirow{2}{*}{4.34} \\
\hline Effluent 3 & 1.0644 & 1.066 & 280 & \\
\hline
\end{tabular}




\begin{tabular}{|c|c|c|c|c|}
\hline Water Type & Wt. Before (g) & Wt. After (g) & Volume (mL) & $\mathrm{TSS}(\mathrm{mg} / \mathrm{L})$ \\
\hline Pond & 1.0671 & 1.0797 & 260 & 48.46153846 \\
\hline Influent & 1.0641 & 1.0679 & 250 & \multirow[b]{2}{*}{62.75992439} \\
\hline Influent & 1.077 & 1.1064 & 279 & \\
\hline Influent & 1.0943 & 1.0984 & 250 & \multirow[b]{2}{*}{130.5283757} \\
\hline Influent & 1.0642 & 1.1268 & 261 & \\
\hline Influent & 1.1094 & 1.1127 & 250 & \multirow[b]{2}{*}{110.2857143} \\
\hline Influent & 1.0739 & 1.1285 & 275 & \\
\hline Effluent & 1.0663 & 1.0759 & 517 & 18.56866538 \\
\hline Effluent & 1.0776 & 1.0804 & 250 & \multirow[b]{2}{*}{12.82527881} \\
\hline Effluent & 1.0637 & 1.0678 & 288 & \\
\hline Effluent & 1.0825 & 1.0851 & 250 & \multirow[b]{2}{*}{13.13320826} \\
\hline Effluent & 1.0585 & 1.0629 & 283 & \\
\hline
\end{tabular}

200 GPM

$\begin{array}{lllll}\text { Water Type } & \text { Wt. Before (g) } & \text { Wt. After (g) } & \text { Volume (mL) } & \text { TSS (mg/L) } \\ \text { Pond 1 } & 1.0723 & 1.0741 & 250 & 9.65 \\ \text { Pond 2 } & 1.0979 & 1.101 & 258 & \\ \text { Influent 1 } & 1.0954 & 1.096 & 250 & 35.60 \\ \text { Influent 1 } & 1.1216 & 1.1404 & 295 & \\ \text { Influent 2 } & 1.1077 & 1.1105 & 250 & 39.77 \\ \text { Influent 2 } & 1.0788 & 1.097 & 278 & \\ \text { Influent 3 } & 1.0839 & 1.0857 & 250 & 26.22 \\ \text { Influent 3 } & 1.0698 & 1.082 & 284 & \\ \text { Effluent 1 } & 1.0667 & 1.0673 & 250 & 2.61 \\ \text { Effluent 1 } & 1.0533 & 1.0541 & 287 & \\ \text { Effluent 2 } & 1.0406 & 1.0412 & 250 & \\ \text { Effluent 2 } & 1.0482 & 1.0508 & 297 & \\ \text { Effluent 3 } & 1.04 & 1.0423 & 250 & \\ \text { Effluent 3 } & 1.0463 & 1.0478 & 268 & \end{array}$

\section{Appendix C. Raw data from oil testing}

20 GPM

\begin{tabular}{|l|l|l|l|l|l|}
\hline Sample & $\begin{array}{l}\text { Volume } \\
(\mathrm{mL})\end{array}$ & $\begin{array}{l}\text { Initial Weight } \\
(\mathrm{g})\end{array}$ & $\begin{array}{l}\text { Final Weight } \\
(\mathrm{g})\end{array}$ & $\begin{array}{l}\text { Weight of } \\
\text { Oil }(\mathrm{mg})\end{array}$ & $\begin{array}{l}\text { Concentration } \\
(\mathrm{mg} / \mathrm{L})\end{array}$ \\
\hline Influent 1 & 1135 & 115.9518 & 115.971 & 19.2 & 16.92 \\
\hline
\end{tabular}




\begin{tabular}{|l|l|l|l|l|l|}
\hline Influent 2 & 985 & 118.5586 & 118.5802 & 21.6 & 21.93 \\
\hline Influent 3 & 1140 & 115.8391 & 115.8558 & 16.7 & 14.65 \\
\hline Effluent 1 & 1025 & 119.3423 & 119.3522 & 9.9 & 9.66 \\
\hline Effluent 2 & 995 & 116.7404 & 116.7492 & 8.8 & 8.84 \\
\hline Effluent 3 & 1050 & 115.7479 & 115.7567 & 8.8 & 8.38 \\
\hline
\end{tabular}

60 GPM

\begin{tabular}{|l|l|l|l|l|l|}
\hline Sample & $\begin{array}{l}\text { Volume } \\
(\mathrm{mL})\end{array}$ & $\begin{array}{l}\text { Initial Weight } \\
(\mathrm{g})\end{array}$ & $\begin{array}{l}\text { Final Weight } \\
(\mathrm{g})\end{array}$ & $\begin{array}{l}\text { Weight of } \\
\text { Oil }(\mathrm{mg})\end{array}$ & $\begin{array}{l}\text { Concentration } \\
(\mathrm{mg} / \mathrm{L})\end{array}$ \\
\hline Influent 1 & 960 & 115.9516 & 115.9653 & 13.7 & 14.27 \\
\hline Influent 2 & 945 & 118.5572 & 118.5606 & 3.4 & 3.60 \\
\hline Influent 3 & 1035 & 119.3638 & 119.3792 & 15.4 & 14.88 \\
\hline Effluent 1 & 955 & 116.7575 & 116.76 & 2.5 & 2.62 \\
\hline Effluent 2 & 1000 & 115.7535 & 115.7584 & 4.9 & 4.90 \\
\hline Effluent 3 & 990 & 115.8632 & 115.8698 & 6.6 & 6.67 \\
\hline
\end{tabular}

150 GPM

\begin{tabular}{|l|l|l|l|l|l|}
\hline Sample & $\begin{array}{l}\text { Volume } \\
(\mathrm{mL})\end{array}$ & $\begin{array}{l}\text { Initial Weight } \\
(\mathrm{g})\end{array}$ & $\begin{array}{l}\text { Final Weight } \\
(\mathrm{g})\end{array}$ & $\begin{array}{l}\text { Weight of } \\
\text { Oil }(\mathrm{mg})\end{array}$ & $\begin{array}{l}\text { Concentration } \\
(\mathrm{mg} / \mathrm{L})\end{array}$ \\
\hline Influent 1 & 910 & 115.8549 & 115.8654 & 10.5 & 11.54 \\
\hline Influent 2 & 955 & 115.7508 & 115.7656 & 14.8 & 15.50 \\
\hline Influent 3 & 965 & 115.9791 & 115.9909 & 11.8 & 12.23 \\
\hline Effluent 1 & 1025 & 116.7784 & 116.7854 & 7 & 6.83 \\
\hline Effluent 2 & 975 & 118.6 & 118.6064 & 6.4 & 6.56 \\
\hline Effluent 3 & 1020 & 119.3434 & 119.3532 & 9.8 & 9.61 \\
\hline
\end{tabular}

200 GPM

\begin{tabular}{|l|l|l|l|l|l|}
\hline Sample & $\begin{array}{l}\text { Volume } \\
(\mathrm{mL})\end{array}$ & $\begin{array}{l}\text { Initial Weight } \\
(\mathrm{g})\end{array}$ & $\begin{array}{l}\text { Final Weight } \\
(\mathrm{g})\end{array}$ & $\begin{array}{l}\text { Weight of } \\
\text { Oil }(\mathrm{mg})\end{array}$ & $\begin{array}{l}\text { Concentration } \\
(\mathrm{mg} / \mathrm{L})\end{array}$ \\
\hline Influent 1 & 915 & 115.82 & 115.8615 & 41.5 & 45.36 \\
\hline Influent 2 & 1060 & 116.7615 & 116.7798 & 18.3 & 17.26 \\
\hline Influent 3 & 925 & 115.7302 & 115.7552 & 25 & 27.03 \\
\hline Effluent 1 & 1025 & 119.3423 & 119.3497 & 7.4 & 7.22 \\
\hline Effluent 2 & 995 & 115.9663 & 115.9709 & 4.6 & 4.62 \\
\hline Effluent 3 & 1050 & 118.5663 & 118.5697 & 3.4 & 3.24 \\
\hline
\end{tabular}

